\title{
Quellen- und Literaturverzeichnis
}

Die Zitierweisen der antiken Autoren orientiert sich an den Vorgaben des Thesaurus Linguae Latinae (lateinische Autoren); G. W. H. Lampe, A Patristic Greek Lexicon, Oxford 1961 (griechische christliche Autoren). Die Abkürzungen für Zeitschriften entsprechen den Abkürzungsverzeichnissen der Année Philologique und der Theologischen Realenzyklopädie (Berlin/New York 21994). Zusätzlich bzw. davon abweichend wurden folgende Abkürzungen verwendet:

AASS = Acta Sanctorum; zitiert nach der 68 Bände umfassenden Ausgabe Antwerpen, Brüssel, Paris 1643-1940, die seit 2006 als Volltextdatenbank verfügbar ist (http://acta.chadwyck.co.uk/; für den Editionsplan der Ausgabe, von der die Nachdrucke Venedig 1734-1760 u. Paris 1863-1870 leicht abweichen, vgl. die von den Bollandisten verwaltete URL http://www.kbr.be/ socboll/)

ACO $=$ Acta Conciliorum Oecumenicorum, series I, ed. Eduard Schwartz/Johannes Straub, Berlin 1914-1984

BHL = Bibliotheca Hagiographica Latina Antiquae et Mediae Aetatis, ed. Socii Bollandiani, 2 Bde., Brüssel 1898-1901, Novum Supplementum ed. Henri Fros, Brüssel 1986

CC $=$ Corpus Christianorum. Series Latina, Turnhout 1954 -

$\mathrm{CTh}=$ Codex Theodosianus, ed. Theodor Mommsen, Berlin 1905

CJ $=$ Codex Iustianianus, ed. Paul Krüger, Berlin 1877

Coll. Avell. = Collectio Avellana, ed. Otto Günther (CSEL 35), Wien u. a. 1895

Comm. MH = Hippolyte Delehaye, Commentarius perpetuus in Martyrologium Hieronymianum (AASS Nov. II, 2), Brüssel 1931

Corpus $=$ Richard Krautheimer/Wolfgang Frankl/Spencer Corbett, Corpus basilicarum christianarum Romae. Le basiliche paleocristiane di Roma (IV - IX Sec.), 5 Bde., Vatikanstadt 1937-1980

CSEL $=$ Corpus Scriptorum Ecclesiasticorum Latinorum, Wien u. a. 1866 -

de Rossi, Inscr. = Giovanni B. de Rossi, Inscriptiones christianae urbis Roma septimo saeculo antiquiores, 2 Bde., Rom 1857-1888

GCS = Die griechischen christlichen Schriftsteller der ersten Jahrhunderte, Leipzig/Berlin 1897 - 
$\mathrm{GeV}=$ Gelasianum vetus: Liber sacramentorum romanae aeclesiae ordinis anni circuli (Cod. Vat. Reg. lat. 316/Paris Bibl. Nat. 7193, 41/56) (Sacramentarium Gelasianum), ed. Leo K. Mohlberg, Rom ${ }^{31981}$

ICUR = Inscriptiones christianae urbis Romae septimo saeculo antiquiores, nova series, ed. Angelo Silvagni u. a., 10 Bände, Rom 1922-1992

ILCV = Inscriptiones latinae christianae veteres, ed. Ernst Diehl, 4 Bde., Berlin 21961 1967

LP = Liber Pontificalis; zitiert - falls nicht ausdrücklich anders vermerkt - nach der Ausgabe von Duchesne/Vogel, Paris 1886-1955

LTUR = Lexicon topographicum urbis Romae, hrsg. von E. Margareta Steinby, 6 Bde., Rom 1993-2000

LTUR, Suburbium $=$ Lexicon topographicum urbis Romae. Suburbium, hrsg. von Adriano La Regina, Rom 2001 -

Mansi $=$ Giovanni D. Mansi, Sacrorum conciliorum nova et amplissima collectio, 31 Bde., Florenz/Venedig 1759-1798 (erweitert 53 Bde., Paris 1901-1927 [ND Graz 1960-1961], danach zitiert)

$\mathrm{MH}=$ Martyrologium Hieronymianum, ed. Giovanni B. de Rossi/Louis Duchesne (AASS Nov. II, 1), Brüssel 1894

Mombritius $=$ Boninus Mombritius, Sanctuarium seu Vitae Sanctorum, Mailand o. J. (vor 1480), zit. nach der ergänzten Neuauflage Paris 1910 (2 Bde., ND Hildesheim 1978)

PG = Jacques P. Migne, Patrologiae completus cursus. Series Graeca, Paris 1857-1866

PL = Jacques P. Migne, Patrologiae completus cursus. Series Latina, Paris 1844-1855

RIC = The Roman Imperial Coinage, ed. Harold Mattingly u. a., London 1923-1994

SC $=$ Sources chrétiennes, Paris 1943 -

\section{Quellen (Textausgaben, Übersetzungen, Kommentare)}

Standardausgaben antiker Autoren (Vergil, Cicero, Seneca o. ä.) werden nicht eigens aufgeführt.

Acta Iustini: Acta Iustini, ed. Anton Hilhorst, übers. Silvia Ronchey, in: Atti e passioni dei martiri, hrsg. von A. A. R. Bastiaensen, Mailand 1987, 47-57

Acta Maximiliani: Acta Maximiliani, ed. Anton A. R. Bastianesen, übers. Giochino Chiarini, in: Atti e passioni dei martiri, hrsg. von Anton A. R. Bastiaensen, Mailand 1987, 233-245 
Acta sincera graeca sanctorum Cyrici et Iulittae, ed. Wilhem van Hooff, in: AB 1, 1882, $192-$ 207

Actus et visio martyrum Luci, Montani et ceterorum comitum: François Dolbeau, La passion des saints Lucius et Montanus. Histoire et édition du texte, in: REAug 29, 1983, 3982

Actus Petri cum Simone: Acta apostolorum apocrypha, ed. Richard A. Lipsius/Maximilian Bonnet, Bd. 1, Leipzig 1891, 45-103

Actus Silvestri: Mombritius II, 508-531

Agnellus, liber pontificalis: Agnelli Ravennatis Liber pontificalis ecclesiae Ravennatis, cura et studio Deborah Mauskopf Deliyannis (CC, continuatio mediaevalis 199), Turnhout 2006

Ambrosius, de excessu fratris Satyri: Sancti Ambrosii de excessu fratris, ed. Otto Faller (CSEL 73), Wien 1955, 207-325

Ambrosius, de Nabuthae: Sancti Ambrosii de Nabuthae, ed. Karl Schenkl (CSEL 32, 2), Wien u. a. 1897, 467-516

Ambrosius, de officiis: Saint Ambroise, Les devoirs. Texte établi traduit et annoté par Maurice Testard, 2 Bde., Paris 1984/1992

Ambrosius, de Tobia: Sancti Ambrosii de Tobia, ed. Karl Schenkl (CSEL 32, 2), Wien u. a. $1897,517-573$

Ambrosius, epistulae: Sancti Ambrosii epistulae et acta, rec. Otto Faller/Michaela Zelzer, 4 Bde. (CSEL 82), Wien 1968/1996

Ambrosius, epistulae extra collectionem: Sancti Ambrosii epistulae et acta, rec. Otto Faller/Michaela Zelzer, Bd. 3 (CSEL 82, 3), Wien 1982, 141-311

Ambrosius, exhortatio virginitatis: Sancti Ambrosii episcopi Mediolanensis opera, Bd. 14, 2: de virginitate, de institutione virginis, exhortatio virginitatis. Textum post E. Cazzinaga et Maurinam editionem Franco Gori recognovit, Mailand/Rom 1989, 197-271

Ambrosius, de paenitentia: Ambroise de Milan, La penitence. Texte latin, introduction, traduction et notes de Roger Gryson (SC 179), Paris 1971

Ammianus Marcellinus, res gestae: Ammiani Marcellini rerum gestarum libri qui supersunt, ed. Wolfgang Seyfarth, 2 Bde., Leipzig 1978

Anonymus post Dionem: Fragmenta Historicorum Graecorum, ed. von Karl Müller, Bd. 4, Paris 1851, 191-199

Anonymus Valesianus: Ingemar König, Aus der Zeit Theoderichs des Großen. Einleitung, Text, Übersetzung und Kommentar einer anonymen Quelle, Darmstadt 1997

Arator, historia apostolica: Aratoris Subdiaconi Historia Apostolica, cura et studio Árpád E. Orbán, 2 Bde. (CC 130, 130A), Turnhout 2006 
Arnobius v. Sicca, adversus nationes: Arnobii adversus nationes libri VII, rec. August Reifferscheid (CSEL 4), Wien 1875

Arnobius d. J., praedestinatus: Arnobii Iunioris Praedestinatus qui dicitur, ed. Franco Gori (CC 25B), Turnhout 2000

Arnobius d. J., liber ad Gregoriam: Germain Morin, Études, textes, découverts. Contributions à la littérature et à l'histoire des douze premiers siècles, Bd. 1, Paris 1913, 383-439

Athanasius, historia arianorum: Athanasius, Werke, Bd. 2, 1: Die Apologien, ed. HansGeorg Opitz, Berlin 1935/1941, 183-230

Athanasius, apologia secunda contra Arianos: Athanasius, Werke, Bd. 2, 1: Die Apologien, ed. Hans-Georg Opitz, Berlin 1935/1941, 87-168

Athenaios, deipnosophistai: Athenaeus, The Deipnosophists, ed. u. übers. Charles B. Gulick, 7 Bde., Cambridge (Mass.) 1927-1941

Augustinus, breviculus collationis cum Donatistis: Sancti Aureli Augustini scripta contra Donatistas, Teil 3, ed. Michael Petschenig (CSEL 53), Wien u. a. 1910, 37-92

Augustinus, confessiones: Sancti Augustini confessionum libri XIII, ed. Lucas Verheijen (CC 27), Turnhout 1981

Augustinus, contra Cresconium: Sancti Aureli Augustini scripta contra donatistas, Teil 2 (CSEL 52), ed. Michael Petschenig, Wien u. a. 1909, 323-582

Augustinus, contra epistulam fundamenti: Sancti Aureli Augustini contra epistulam quam vocant fundamenti, ed. Joseph Zycha (CSEL 25), Wien 1891, 191-248

Augustinus, contra partem Donati post gesta: Sancti Aureli Augustini scripta contra donatistas, Teil 3, ed. Michael Petschenig (CSEL 53), Wien u. a. 1910, 95-162

Augustinus, de cura pro mortuis gerenda: Sancti Aureli Augustini de cura pro mortuis gerenda, ed. Joseph Zycha (CSEL 41), Wien u. a. 1900, 619-660

Augustinus, de baeresibus: Sancti Aurelii Augustini de haeresibus, cura et studio Roland Vander Plaetse/Clemens Beukers, in: Aurelii Augustini opera, Bd. XV 2 (CC 46), Turnhout 1969, 263-345

Augustinus, ennarationes in psalmos: Sancti Augustini ennarationes in psalmos, ed. Eligius Dekkers/Jean Fraipont, 3 Bde. (CC 38-40), Turnhout 1956

Augustinus, epistulae: S. Aurelii Augustini Hipponensis episcopi epistulae, rec. A. Goldbacher (CSEL 34 [1 u. 2], 44, 57), Wien 1895-1911

Augustinus, sermones (Morin): Sancti Augustini sermones post Maurinos reperti, ed. Germain Morin (Miscellanea Agostiniana 1), Rom 1930

Augustinus, sermones (Dolbeau): Augustin d'Hippone, Vingt-six sermons au peuple d'Afrique. Retrouvés a Mayence, édités et commentés par François Dolbeau, Paris 1996 
Augustinus, de unico baptismo: Sancti Aureli Augustini scripta contra Donatistas, Teil 3, rec. M. Petschenig (CSEL 53), Wien u. a. 1910, 1-34

Aurelius Victor, liber de caesaribus: Sexti Aurelii Victoris liber de caesaribus, ed. Franz Pichlmayr/Roland Gruendel, Leipzig 1966, 75-129

Ausonius, epistulae: The Works of Ausonius. Edited with Introduction and Commentary by Roger P. H. Green, Oxford 1991, 193-231

Basileios v. Caesarea, epistulae: Saint Basile, Lettres. Texte établi et traduit par Yves Courtonne, 3 Bde., Paris 1957-1966

Caesarius von Arles, sermones: Sancti Caesarii Arelatensis sermones, ed. Germain Morin, 2 Bde. (CC 103f.), Turnhout 1953

Caesarius von Arles, regula ad virgines: Césaire d'Arles, Euvres monastiques, Bd. 1: Cuvres pour les moniales. Introduction, texte critique, traduction et notes par Adalbert de Vogüé/Joël Courreau (SC 345), Paris 1988, 169-273

Canon missae: Le canon de la messe romaine. Édition critique, introduction et notes par Bernard Botte, Löwen 1935

Cassiodor, variae: Cassiodoris Senatoris Variae, rec. Theodor Mommsen (MGH AA XII), Berlin 1894, 1-385

Cassiodor, chronica: Chronica minora saec. IV. V. VI. VII, ed. Theodor Mommsen, Bd. 2 (MGH AA XI), Berlin 1894, 109-161

Cassius Dio, historia romana: Cassii Dionis Cocceiani historiarum romanarum quae supersunt ed. U. Philip Boissevain, 5 Bde., Berlin 1895-1931

Chromatius v. Aquileia, sermones: Chromace d'Aquilée, Sermons. Introduction, texte critique, notes par Joseph Lemarié, traduction par Henri Tardif, 2 Bde. (SC 154, 164), Paris $1969 / 1971$

Cicero, de officiis: M. Tulli Ciceronis de officiis, rec. C. Atzert, Leipzig 1963

Claudian, carmina maiora: Claudii Claudiani carmina, ed. John B. Hall, Leipzig 1985, 1 288

Codices latini antiquores. A Paleographical Guide to Latin Manuscripts prior to the Ninth Century, ed. von E. A. Lowe, 11 Bde. u. Suppl., Oxford 1934-1971

Commentarii fratrum Arvalium qui supersunt. Les copies épigraphiques des protocoles annuels de la confrérie arvale (21 av. - 304 ap. J.-C.), ed. John Scheid, Rom 1998

Concilia Africae a. 345 - a. 525, ed. Charles Munier (CC 149), Turnhout 1974

Concilia Galliae a. 314 - a. 506, ed. Charles Munier (CC 148), Turnhout 1963

Concilia Galliae a. 511 - a. 695, ed. Carl de Clercq (CC 148A), Turnhout 1963

Concilios visigóticos e hispano-romanos, ed. José Vives/Tomás M. Martínez/Gonzalo Martínez Díez, Barcelona/Madrid 1963 
Concilium Chalcedonense, canones: ACO II, 1, 2: Concilium Chalcedonense, Actio secunda. Epistularum collectio B. Actiones III-VII, ed. Eduard Schwartz, Berlin $1933,158-163$

Concilium Nicaenum a. 325, canones: Discipline générale antique (IIe - IXe s.), Bd. 1, 1: Les canons des conciles oecuméniques, ed. Périclès-Pierre Joannou (Pontificia commissione per la redazione del codice di diritto canonico orientale, Fonti 9), Rom 1962, 23-41 (griechischer und lateinischer Text, französische Übersetzung)

Concilium Serdicense, canones: Turner 1899-1933, Bd. 1, 441-560

Constitutiones apostolorum: Les constitutions apostoliques. Introduction, texte critique, traduction et notes par Marcel Metzger, 3 Bde. (SC 320, 329, 336), Paris 1985-1987

Constitutum Silvestri, ed. Wirbelauer 1993, 228-247 (1. Fassung), 308-315 (2. Fassung)

Curiosum urbis Romae regionum XIIII, ed. Roberto Valentini/Giuseppe Zucchetti, Codice topografico della della città di Roma, Bd. 1, Rom 1940, 89-164

Cyprian, de bono patientiae: Thasci Caecili Cypriani de bono patientiae, in: Cypriani opera omnia, ed. Wilhelm Hartel, Bd. 1 u. 2 (CSEL 3, 1 u. 2), Wien 1868/1871, 395415

Cyprian, epistulae: Sancti Cypriani Episcopi Epistularium, ed. G. F. Diercks, 2 Bde. (CC 3B-C), Turnhout 1994/1996; Sancti Cypriani Episcopi Epistularium. Prolegomena, cura et studio G. F. Diercks/G. W. Clark (CC 3D), Turnhout 1999

Cyprian, de habitu virginum: Thasci Caecili Cypriani de habitu virginum, in: Cypriani opera omnia, ed. Wilhelm Hartel, Bd. 1 u. 2 (CSEL 3, 1 u. 2), Wien 1868/1871, 185-205

Cyprian, de lapsis: Thasci Caecili Cypriani de lapsis, in: Cypriani opera omnia, ed. Wilhelm Hartel, Bd. 1 u. 2 (CSEL 3, 1 u. 2), Wien 1868/1871, 235-264

Cyprian, de opere et eleemosynis: Sancti Cypriani de opere et eleemosynis, ed. Manlio Simonetti (CC 3 A), Turnhout 1976, 53-72

Cyprian, de unitate ecclesiae: Thasci Caecili Cypriani de catholicae ecclesiae unitate, in: Cypriani opera omnia, ed. Wilhelm Hartel, Bd. 1 u. 2 (CSEL 3, 1 u. 2), Wien 1868/ $1871,207-233$

Damasus, Epigramme: Epigrammata damasiana, recensuit et adnotavit Antonius Ferrua, Vatikanstadt 1942

Damasus, epistula 1 (confidimus quidem): Eduard Schwartz, Über die Sammlung des Cod. Veronensis LX, in: ZNW 35, 1936, 1-23, hier $19 f$.

Damasus, epistula 5 (decursis litteris): Epistularum Romanorum Pontificum ad vicarios per Illyricum aliosque episcopos Collectio Thessalonicensis, rec. Carlos Silva-Tarouca, Rom 1937, 16-18 
Damasus, epistula ad Gallos episcopos (canones synodi Romanorum ad Gallos episcopos): La décrétale $A d$ Gallos Episcopos: son texte et son auteur. Texte critique, traduction française et commentaire par Yves-Marie Duval, Leiden 2005

Decretum Gelasianum de libris recipiendis et non recipiendis, ed. Ernst v. Dobschütz, Leipzig 1912

De locis sanctis martyrum, quae sunt foris civitatis Romae. Ecclesiae quae intus Romae babentur, ed. Roberto Valentini/Giuseppe Zucchetti, Codice topografico della della città di Roma, Bd. 2, Rom 1942, 101-131

Depositio Marcellini papae: ed. u. übers. Wirbelauer 1993, 284-301

Didascalia apostolorum: The Didascalia Apostolorum in Syriac, ed. and transl. by Arthur Vööbus, 4 Bde. (CSCO, Scriptores syri 175f., 179f.), Löwen 1979

Diogenes Laertios, vitae philosophorum: Diogeni Laertii vitae philosophorum, ed. H. S. Lang, 2 Bde., Oxford 1964

Ennodius, libellus pro synodo: Magni Felicis Ennodi Opera, ed. Friedrich Vogel (MGH AA VII), Berlin 1885, 48-67

Ephraim der Syrer, hymni paschales: Des heiligen Ephraem des Syrers Paschahymnen (de azymis, de crucifixione, de resurrectione), hsrg. u. übers. von Edmund Beck, 2 Bde. (CSCO, Script. Syri 108 u. 109), Löwen 1964; französ. Übersetzung: Gerardus A. M. Rouwhorst, Les hymnes pascales d'Ephraem de Nisibe. Analyse théologique et recherche sur l'évolution de la fête pascale chrétienne à Nisibe et à Edesse et dans quelques églises voisines au quatrième siècle, Diss. Utrecht 1985, Bd. 2

Epitome de Caesaribus: Pseudo Aurélius-Victor, Abrégé des Césars. Texte établi, traduit et commenté par Michel Festy, Paris 1999

Eusebius v. Caesarea, historia ecclesiastica: Eusebius, Werke, Bd. 2: Die Kirchengeschichte, ed. Eduard Schwartz. Die lateinische Übersetzung des Rufinus, ed. Theodor Mommsen, 2 Bde. (GCS 9, 1. 2), Leipzig 1903/1908

Eusebius v. Caesarea, vita Constantini: Eusebius, Werke, Bd. 1, 1: Über das Leben des Kaisers Konstantin, ed. Friedhelm Winkelmann (GCS 7), Berlin 21991. Kommentar: Eusebius, Life of Constantine. Introduction, Translation and Commentary by Averil Cameron/Stuart G. Hall, Oxford 1999

Festus, epitomae operis de verborum significatu Verrii Flacci: Sexti Pompei Festi de verborum significatione quae supersunt cum Pauli epitome ed. Wallace M. Lindsay, Leipzig 1913

Filastrius von Brescia, diversarum hereseon liber: Sancti Filastrii episcopi Brixiensis diversarum hereseon liber, rec. Friedrich Marx (CSEL 38), Wien u. a. 1938

Gaudentius v. Brescia, sermones: S. Gaudentii episcopi Brixiensis tractatus, rec. Ambrosius Glueck (CSEL 68), Wien u. a. 1936 
Gelasius, epistulae: Andreas Thiel, Epistolae romanorum pontificum genuinae, Bd. 1: a S. Hilaro usque ad S. Hormisdam, Braunsberg 1868, 285-613

Gesta Eusebii presbyteris: AASS Aug. III, 166f.; Mombritius I, 459

Gesta Liberii: ed. u. übers. Wirbelauer 1993, 248-261

Gregor von Nazianz, de vita sua: Gregor von Nazianz, de vita sua. Einleitung, Text, Übersetzung, Kommentar von Christoph Jungck, Heidelberg 1974

Gregor von Nazianz, oratio 5: Grégoire de Nazianze, Discours 4-5 contre Julien. Introduction, texte critique, traduction et notes par Jean Bernardi (SC 309), Paris 1983

Gregor von Nazianz, oratio 8: Grégoire de Nazianze, Discours 6-12. Introduction, texte critique, traduction et notes par Marie-Ange Calvet-Sebasti (SC 405), Paris 1995

Gregor von Nyssa, vita Macrinae: Grégoire de Nysse, Vie de sainte Macrine, introduction, texte critque, traduction, notes et index par Pierre Maraval (SC 178), Paris 1971

Gregor v. Tours, in gloria martyrum: Gregorii episcopi Turonensis miracula et opera minora, ed. Bruno Krusch (MGH script. Merov. I, 2), Hannover 21969 , 34-111

Gregor v. Tours, in gloria confessorum: Gregorii episcopi Turonensis miracula et opera minora, ed. Bruno Krusch (MGH script. Merov. I, 2), Hannover 21969, 294-370

Gregor I., dialogi: Grégoire le Grand, Dialogues. Introduction, texte critique, traduction et notes par Adalbert de Vogüé/Paul Antin, 3 Bde. (SC 251, 260, 265), Paris 1978-1980

Gregor I., epistulae: Gregorii I papae registrum epistolarum, ed. Paul Ewald/Ludwig M. Hartmann, 2 Bde. (MGH epist. I. II), Berlin 1891/1895

Gregor I., homiliae in evangelia: Gregorius Magnus, Homiliae in Evangelia, ed. Raymond Étaix (CC 141), Turnhout 1999

Hermas, pastor: Hermas, Le Pasteur. Introduction, texte critique, traduction et notes par Robert Joly (SC 532), Paris 21968. Kommentar und deutsche Übersetzung: Der Hirt des Hermas, übersetzt und erklärt von Norbert Brox, Göttingen 1991

Herodian, historiai: Herodianus, regnum post Marcum, ed. Carlo M. Lucarini, München/Leipzig 2005

Hieronymus, chronicon: Eusebius, Werke, Bd. 7: Die Chronik des Hieronymus, ed. Rudolf Helm (GCS 47), Berlin ${ }^{31984}$

Hieronymus, commentarii in Ieremiam prophetam: Sancti Hieronymi presbyteri opera I, 3, ed. Siegfried Reiter (CC 74), Turnhout 1960

Hieronymus, commentarii in Isaiam: Sancti Hieronymi presbiteri commentariorum in Esaiam libri I-XVIII, ed. Marc Adriaen (CC 73. 73 A), Turnhout 1963 
Hieronymus, commentarii in Matthaeum: S. Hieronymi presbyteri commentariorum in Matheum libri IV, ed. David Hurst/Marc Adriaen (CC 77), Turnhout 1969

Hieronymus, commentarii in Ezechielem: S. Hieronymi presbyteri commentariorum in Hiezechielem libri XIV, ed. François Glorie (CC 75), Turnhout 1964

Hieronymus, contra Vigilantium: PL 23, 353-368

Hieronymus, de viris illustribus: Hieronymus, liber de viris illustribus - Gennadius, liber de viris illustribus, ed. von Ernest C. Richardson, Leipzig 1896

Hieronymus, epistulae: Saint Jérôme, Lettres. Texte établi et traduit par Jérôme Labourt, 8 Bde., Paris 1949/1963

Hippolytos, refutatio omnium haeresium: Hippolytus, Refutatio omnium haeresium, ed. Miroslav Marcovich, Berlin/New York 1986

Hippolytos, traditio apostolica: Bernard Botte, La tradition apostolique de Saint Hippolyte. Essai de reconstitution, Münster 51989

Historia Augusta: Scriptores Historiae Augustae, ed. Ernst Hohl, 2 Bde., Leipzig 41965; Histoire Auguste Bd. III 1: Vies de Macrin, Diaduménien, Héliogabale. Texte établi, traduit et commenté par Robert Turcan, Paris 1993; Histoire Auguste, Bd. V, 2: Vies de Probus, Firmus, Saturnin, Proculus et Bonose, Carus, Numérien et Carin. Texte établi, traduit et commenté par François Paschoud, Paris 2001

Ignatius v. Antiochia, epistulae: Die Apostolischen Väter, hrsg. u. übers. von Andreas Lindemann/Henning Paulsen, Tübingen 1992, 176-241

Innozenz I., epistula ad Decentium episcopum Egubinum: La lettre du pape Innocent Ier a Décentius de Gubbio (19 mars 416). Texte critique, traduction et commentaire par Robert Cabié, Löwen 1973

Johannes v. Antiochia, historia chronica: Ioannis Antiocheni fragmenta ex historia chronica. Introduzione, edizione critica e traduzione a cura di Umberto Roberto, Berlin/ New York 2005

Irenäus, adversus haereses: Irénée de Lyon, Contre les heresies, ed. u. übers. Adelin Rousseau u. a., 9 Bde. (SC 263f., 293f., 210f., 100, 152f.), Paris 1965-1982

Julian, epistulae: L'empereur Julien, Ouevres complètes, Bd. 1, 2: Lettres et fragments. Texte revu et traduit par Joseph Bidez, Paris 21960

Klemens v. Alexandrien, quis dives salvetur: Clemens Alexandrinus, ed. Otto Stählin, Bd. 3 (GCS 17), Leipzig 1909, 157-191

Konstantin, oratio ad sanctorum coetum: Constantins Rede an die heilige Versammlung, ed. Ivar A. Heikel, in: Eusebius, Werke, Bd. 1 (CGS 7), Leipzig 1902, 149-192

Laktanz, divinae institutiones: L. Caeli Firminai Lactanti opera omnia, Teil 1: divinae institutiones et epitome divinarum institutionum, ed. Samuel Brandt (CSEL 19), Wien u. a. 1890 
Laktanz, de mortibus persecutorum: Lactantius, de mortibus persecutorum, edited and translated by J. L. Creed, Oxford 1984

Laterculus Malalianus: Laterculus imperatorum Romanorum Malalianus, ed. Theodor Mommsen (MGH AA XIII), Berlin 1898, 424-437

Leo I., epistulae: Sancti Leonis Magni romani pontificis opera omnia, Bd. 1, ed. J.-P. Migne, Paris 1881 (PL 54) (Nachdruck aus der Ausgabe von Petrus u. Hieronymus Ballerini, Opera S. Leonis Magni pontificis, Bd. 1, Venedig 1753)

Leo I., sermones. Sancti Leonis Magni romani pontificis tractatus XCVII, rec. Antoine Chavasse, 2 Bde. (CC 138A), Turnhout 1973

Liber Pontificalis: Le Liber Pontificalis. Texte, introduction et commentaire par Louis Duchesne/Cyrille Vogel, 3 Bde., Paris 1886-1955; Gestorum Pontificum Romanorum, Bd. 1: Libri Pontificalis pars prior, ed. von Theodor Mommsen, Berlin 1898

Lukian, de morte Peregrini: Luciani opera, rec. M. D. Macleod, Bd. 3, Oxford 1980, 188205

Martyrium Pionii: Louis Robert, Le martyre de Pionius, hrsg. von Glen W. Bowersock/Christopher P. Jones, Washington 1994

Martyrium Polycarpi: Die Apostolischen Väter, hrsg. u. übers. von Andreas Lindemann/Henning Paulsen, Tübingen 1992, 258-285

Maximus v. Turin, sermones: Maximi episcopi Taurinensis collectionem sermonum antiquam ed. Almut Mutzenbecher (CC 23), Turnhout 1962

Minucius Felix, Octavius: M. Minuci Felicis Octavius, ed. Bernhard Kytzler, Leipzig 1982

Mirabilia urbis Romae, ed. Roberto Valentini/Giuseppe Zucchetti, in: Codice topografico della della città di Roma, Bd. 3, Rom 1946, 1-65

Notitia ecclesiarum urbis Romae, ed. Roberto Valentini/Giuseppe Zucchetti, in: Codice topografico della della città di Roma, Bd. 2, Rom 1942, 67-99

Notitia urbis Romae regionum XIIII, ed. Roberto Valentini/Giuseppe Zucchetti, in: Codice topografico della della città di Roma, Bd. 1, Rom 1940, 164-192

Olympiodor, historikoi logoi: Roger C. Blockley, The Fragmentary Classicising Historians of the Later Roman Empire. Eunapius, Olympiodorus, Priscus and Malchus, Bd. 2: Text, Translation and Historiographical Notes, Liverpool 1983, $151-220$

Optatus von Mileve, contra Parmenianum: Optat de Milève, Traité contre les donatistes. Introduction, texte critique, traduction et notes par Mireille Labrousse, 2 Bde. (SC 412f.), Paris 1995

Ordines Romani: Michel Andrieu, Les Ordines Romani du haut moyen âge, 5 Bde., Löwen 1931-1961 
Orosius, historiae: Pauli Orosii Historiarum adversum paganos libri VII, rec. Karl Zangemeister (CSEL 5), Wien u. a. 1882

Palladius, bistoria Lausiaca: Cuthbert Butler, The Lausiac History of Palladius, Bd. 2: The Greek Text with Introduction and Notes, Cambridge 1904

Panegyrici latini: In Praise of Later Roman Emperors: The Panegyrici latini. Introduction, Translation, and Historical Commentary with the Latin Text of R. A. B. Mynors by C. E. V. Nixon/Barbara Saylor Rodgers, Berkeley u. a. 1994

Passio Agnetis et Emerentianae: AASS Ian. II, 351-354; Mombritius I, 40-44 (griechischer Text: Franchi de' Cavalieri 1899, 76-92)

Passio Alexandri, Eventii et Theodoli: AASS Maii I, 371-375; Mombritius I, 44-49

Passio Anastasiae: Delehaye 1936, 221-249

Passio Anthimi presbyteri, Maximi, Bassi: AASS Maii II, 616-619, Mara 1964, 47-72

Passio Caeciliae: Delehaye 1936, 194-220

Passio Callisti: AASS Oct. VI, 439-441; Mombritius I, 268-271

Passio Cantii, Cantiani et Cantianillae: Jean Mabillon, De liturgia Gallicana libri tres, Paris 1729, 467-470 (BHL 1545); AASS Maii VII, 428-430 (BHL 1546); Mombritius I, 278-280 (BHL 1547)

Passio Christinae: AASS Iulii V, 524-526

Passio Clementis: Mombritius I, 341-344 (griech. Text: Franz X. v. Funk, Patres apostolici, hrsg. von Franz Diekamp, Bd. 2, Tübingen 1913, 51-81)

Passio Cornelii papae: Mombritius I, 373; Emmanuel Schelstrate, Antiquitas ecclesiae illustrata, Bd. 1, Rom 1692, 188-190

Passio Cyriaci et sociorum, ed. Carl de Smedt u. a., in: AB 2, 1883, 247-258

Passio Eugeniae, Proti et Hyacinthi: Mombritius II, 391-397

Passio Eusebii, Pontiani, Vincentii, Peregrini: AASS Aug. V, $115 \mathrm{f}$.

Passio Eusebii presbyteri, Marcelli diaconi et aliorum: AASS Nov. IV, 93-99

Passio Faustinae et Iovitae, ed. Fedele Savio, in: AB 15, 1896, 5-72, 113-159

Passio Felicis episcopi: Kurzfassung (BHL 2857), in: Verrando 1981, 122-125; Langfassung (BHL 2858), ed. Carl de Smedt u. a., in: AB 2, 1883, 322-324

Passio Felicis episcopi Thibiucensis: Hippolyte Delehaye, La passion de S. Félix de Thibiuca, in: AB 39, 1921, 241-276

Passio Felicitatis: AASS Iulii III, 12f.; Mombritius I, 549

Passio Flaviani, Fausti, Dafrosae et Bibianae: Mombritius I, 489 (Kurzfassung der passio Pigmenii) 
Passio Fructuosi, Augurii et Eulogii: Pio Franchi de' Cavalieri, Gli atti di S. Fruttuoso di Tarragona, in: ders., Note agiografiche 8 (Studi e testi 65), Rom 1935, 127-199

Passio Gallicani, Iohannis et Pauli: AASS Iunii V, 37-39 u. 159f.; Mombritius I, 569-572

Passio Getulii, Amantii, Cerealis et Primitivi: AASS Iunii II, 265f.; Mombritius I, $586 f$.

Passio Gordiani et Epimachi: AASS Maii II, 552f.; Mombritius I, $603 f$.

Passio Irenaei episcopi Sirmiensis: Oscar v. Gebhardt, Ausgewählte Märtyreracten und andere Urkunden aus der Verfolgungszeit der christlichen Kirche, Berlin 1902, 162 165

Passio Marcelli: AASS Ian. II, 5-9; Mombritius II, 169-173

Passio Marcellini et Petri: AASS Iunii I, 171-173; Mombritius II, 179-181

Passio Mariani et Iacobi: Pio Franchi de' Cavalieri, La Passio SS. Mariani et Iacobi (Studi e testi 3), Rom 1900

Passio Marii, Marthae, Audifacis et Abbaci: AASS Ian. II, 216-219; Mombritius II, 241244

Passio Nerei et Achillei: AASS Maii III, 6-13

Passio Nicomedis: Mombritius II, 293-295

Passio sanctarum Perpetuae et Felicitatis: Passion de Perpétue et de Félicité suivi des actes. Introduction, texte critique, traduction, commentaire et index par Jacqueline Amat (SC 417), Paris 1996

Passio Pigmenii: Delehaye 1936, 259-263

Passio Polychronii Parmenii Abdon et Sennes Xysti Felicissimi et Agapiti et Laurentii et aliorum sanctorum mense augusto die X: Delehaye 1933 (a), 71-98

Passio Priscae: AASS Ian. II, 184-187

Passio Processi et Martiniani: Franchi de`Cavalieri 1953, 47-52

Passio Quattuor Coronatorum: AASS Nov. III, 748-784

Passio Quirini: AASS Iunii I, 381-383

Passio Rufinae et Secundae: AASS Iulii III, 30f.; Mombritius II, 444f.

Passio Sabinae et Serapiae: AASS Aug. VI, 500-504; Mombritius II, 501-503

Passio Sebastiani: AASS Ian. II, 265-278; Mombritius II, 459-476

Passio Simplicii, Faustini et Beatricis: AASS Iulii VII, 36; Mombritius II, 531f.

Passio Stephani papae: AASS Aug. I, 139-144; Mombritius II, 495-500

Passio Susannae: AASS Feb. III, 61-64 u. Aug. II, 631f.; Mombritius II, 553-559

Passio Xysti, Laurentii et Hippolyti vetus: Verrando 1991, 207-213 
Paulinus v. Mailand, vita Ambrosii: Paulini vita Ambrosii, ed. Antoon A. R. Bastiaensen, traduzione Luca Canali, in: Vite dei santi, hrsg. von Christine Mohrmann, Bd. 3, Mailand 1975, 51-125

Paulinus v. Nola, epistulae: Sancti Pontii Meropii Paulini Nolani epistulae, ed. Wilhelm Hartel (CSEL 29), Wien 21999

Paulinus v. Nola, carmina: Sancti Pontii Meropii Paulini Nolani carmina, ed. Wilhelm Hartel (CSEL 30), Wien 21999

Petros Patrikios, de sententiis: Excerpta historica iussu imperatoris Constantini Porphyrogeniti confecta, Bd. IV: Excerpta de sententiis, ed. Ursulus P. Boissevain, Berlin 1906, 241-271

Philostorgios, historia ecclesiastica: Philostorgius, Kirchengeschichte, ed. Joseph Bidez/ Friedhelm Winkelmann (GCS 21), Berlin 21972

Photios, bibliothecae codices: Photius, Bibliothèque. Texte établi et traduit par René Henry, 9 Bde., Paris 1959-1991

Prokop, bella: Procopii Caesariensis opera omnia, ed. Jacob Haury, Bd. 1f.: de bellis libri I-VIII, Leipzig 1962/1963

Prosper, epitoma chronicorum: Prosperi Tironis epitoma chronicon, ed. Theodor Mommsen (MGH AA IX), Berlin 1892, 341-485

Prudentius, contra Symmachum: Prudence, Psychomachie, Contre Symmaque. Texte établi et traduit par M. Lavarenne, Paris 1963

Prudentius, peristephanon: Prudence, Le livre des couronnes, Dittochaeon, Épilogue. Texte établi et traduit par M. Lavarenne, Paris 1951

Ps.-Linus, Martyrium Petri: Acta apostolorum apocrypha, ed. Richard A. Lipsius/Maximilian Bonnet, Bd. 1, Leipzig 1891, 1-22

Ps.-Marcellus, Passio Petri et Pauli: Acta apostolorum apocrypha, ed. Richard A. Lipsius/Maximilian Bonnet, Bd. 1, Leipzig 1891, 118-177

Roman Statutes, hrsg. von Michael Crawford, 2 Bde., London 1996

Rufinus, historia ecclesiastica: Eusebius, Werke, Bd. 2: Die Kirchengeschichte, ed. Eduard Schwartz. Die lateinische Übersetzung des Rufinus, ed. Theodor Mommsen (GCS 9, 1. 2), 2 Bde., Leipzig 1903/1908

Rutilius Namatianus, de reditu suo: Rutilius Claudius Namatianus, De reditu suo sive Iter Gallicum, hrsg., eingel. u. erkl. von Ernst Doblhofer, 2 Bde., Heidelberg 1972/ 1977

Sacramentarium Veronense (Cod. Bibl. Capit. Veron. LXXXV [80]), ed. von Leo C. Mohlberg, Rom 1956

Scholia arriana in concilium Aquileiense: Scolies ariennes sur le concile d'Aquilée. Introduction, texte latin, traduction et notes par Roger Gryson (SC 267), Paris 1980 
Servius, commentarius in Vergilii opera: Servii grammatici qui feruntur in Vergilii carmina commentarii, erc. Georg Thilo/Hermann Hagen, 3 Bde., Leipzig 1881-1887

Sidonius Apollinaris, epistulae: Sidoine Apollinaire, Lettres. Texte établi et traduit par André Loyen, 2 Bde., Paris 1970

Sokrates, historia ecclesiastica: Sokrates, Kirchengeschichte, ed. Günther C. Hansen (GCS, n. F. 1), Berlin 1995

Sozomenos, historia ecclesiastica: Sozomenus, Kirchengeschichte, ed. Joseph Bidez/ Günther C. Hansen (GCS, n. F. 4), Berlin 21995

Symmachus, epistulae: Symmaque, Lettres. Texte établi, traduit et commenté par JeanPierre Callu, 4 Bde., Paris 1972/2002

Symmachus, relationes: Q. Aurelii Symmachi quae supersunt, ed. Otto Seeck (MGH AA VI), Berlin 1883, 279-317

Tertullian, ad martyras: Quinti Septimi Florentis Tertulliani ad martyras, cura et studio Eligius Dekkers, in: Tertulliani opera, Bd. 1 (CC 1), Turnhout 1954, 1-8

Tertullian, ad uxorem: Quinti Septimi Florentis Tertulliani ad uxorem libri duo, cura et studio Emil Kroymann, in: Tertulliani opera, Bd. 1 (CC 1), Turnhout 1954, 371-394

Tertullian, apologeticum:Tertullian, Apologeticum - Verteidigung des Christentums, hrsg., übers. u. erl. von Carl Becker, München 1952

Tertullian, de anima: Quinti Septimi Florentis Tertulliani de anima, hrsg., eingel. u. komm. von Jan H. Waszink, Amsterdam 1947

Tertullian, de ieiunio: Quinti Septimi Florentis Tertulliani de ieiunio adversus psychicos, cura et studio August Reifferscheid/Georg Wissowa, in: Tertulliani opera, Bd. 2 (CC 2), Turnhout 1954, 1255-1277

Tertullian, de monogamia: Quinti Septimi Florentis Tertulliani de spectaculis, cura et studio Eligius Dekkers, in: Tertulliani opera, Bd. 2 (CC 2), Turnhout 1954, 1227-1253

Tertullian, de pudicitia: Quinti Septimi Florentis Tertulliani de spectaculis, cura et studio Eligius Dekkers, in: Tertulliani opera, Bd. 2 (CC 2), Turnhout 1954, 1279-1330

Tertullian, de spectaculis: Quinti Septimi Florentis Tertulliani de spectaculis, cura et studio Eligius Dekkers, in: Tertulliani opera, Bd. 1 (CC 1), Turnhout 1954, 225-253

Tertullian, de testimonio animae: Quinti Septimi Florentis Tertulliani de testimonio animae, cura et studio R. Willems, in: Tertulliani opera, Bd. 1 (CC 1), Turnhout $1954,173-183$

Theodoret, historia ecclesiastica: Theodoret, Kirchengeschichte, ed. Léon Parmentier/ Günther C. Hansen (GCS, n. F. 5), Berlin ${ }^{31998}$

Turner, Cuthbert H., Ecclesiae occidentalis monumenta iuris antiquissima (EOMIA), 2 Bde., Oxford 1899-1939 
Varro, de lingua latina: M. Terentii Varronis de lingua latina quae supersunt, rec. Georg Goetz/Friedrich Schöll, Amsterdam 1964

Victricius v. Rouen, de laude sanctorum: Victricii Rotomagensis de laude sanctorum, ed. I. Mulders/R. Demeulenaere (CC 64), Turnhout 1985, 53-93

Vita Melaniae iunioris: griechische Fassung: Vie de Sainte Mélanie. Texte grec, introduction, traduction et notes par Denys Gorce (SC 90), Paris 1962; lateinische Fassung: Mariano Rampolla del Tindaro, Santa Melania Giuniore, senatrice romana. Documenti contemporanei e note, Rom 1905, 3-40; Kommentar: s. E. Clark, 1984

Vita Melloni: AASS Oct. IX, 570-572; Mombritius II, 285 f.

Vita Petri Hiberii: Petrus der Iberer. Ein Charakterbild zur Kirchen- und Sittengschichte des fünften Jahrhunderts. Syrische Übersetzung einer um das Jahr 500 verfaßten griechischen Biographie, herausgegeben und übersetzt von Richard Raabe, Leipzig 1895

Vita Potentianae et Praxedis: AASS Maii IV 299f.; Mombritius II, 353f. u. 390f.

Zosimos, nea historia: Zosime, Histoire Nouvelle. Texte établi et traduit par François Paschoud, Paris 22000

\section{Sekundärliteratur}

Achelis, Hans, Acta SS. Nerei et Achillei. Text und Untersuchung, Leipzig 1893

Achelis, Hans, Die Martyrologien, ihre Geschichte und ihr Wert, AGWG.PH 3, 3, Berlin 1900

Aiello, Vincenzo, Costantino, la lebbra e il battesimo di Silvestro, in: Costantino il Grande. Dall'antichità all'umanesimo. Colloquio sul Cristianesimo nel mondo antico, Macerata 18.-20. Dezember 1990, hrsg. von Giorgio Bonamente/Franca Fusto, Bd. 1, Macerata 1992, 17-58

Aigrain, René, L’hagiographie. Ses sources - Ses methodes - Son histoire, Brüssel 1953 (bibliographisch aktualisierte Neuausgabe von Robert Godding, Brüssel 2000)

Aimone, Pier V., Gli autori delle falsificazioni simmachiane, in: Il papato di San Simmaco (498-514), hrsg. von Giampaolo Mele/Natalino Spaccapelo, Cagliari 2000, 5377

Alborino, Verena, Das Silberkästchen von San Nazaro in Mailand, Bonn 1981

Alchermes, Joseph D., Petrine Politics: Pope Symmachus and the Rotunda of St. Andrew at Old St. Peter's, in: CHR 81, 1995, 1-40

Alcock, Susan E., The Reconfiguration of Memory in the Eastern Roman Empire, in: Empires. Perspectives from Archaeology und History, hrsg. von Susan E. Alcock u. a., Cambridge 2001, 323-350 
Alcock, Susan E., Archaeologies of the Greek Past. Landscape, Monuments, and Memories, Cambridge 2002

Alcock, Susan E./van Dyke, Ruth M., Archaeologies of Memory: An Introduction, in: Archaeologies of Memory, hrsg. von Ruth M. van Dyke/Susan E. Alcock, Malden 2003, 1-13

Alfarano, Tiberio, De basilicae Vaticanae antiquissima et nova structura, ed. Michele Cerrati, Rom 1914

Alföldi, Andreas, On the Foundation of Constantinople: A Few Notes, in: JRS 37, 1947, 10-16

Alföldi, Andreas, The Conversion of Constantine and Pagan Rome, Oxford 1948

Alföldi, Andreas, A Conflict of Ideas in the Late Roman Empire. The Clash between the Senate and Valentinian I, Oxford 1952

Alföldi, Andreas, Die monarchische Repräsentation im römischen Kaiserreiche, Darmstadt 1970

Alföldi, Andreas/Alföldi, Elisabeth, Die Kontorniat-Medaillons, Teil 2: Text, Berlin/ New York 1990

Alföldy, Géza, Difficillima tempora: Urban Life, Inscriptions and Mentality in Late Antique Rome, in: Urban Centers and Rural Contexts in Late Antiquity, hrsg. von Thomas S. Burns/John W. Eadle, East Lansing 2001, 3-24

Amedick, Rita, Die antiken Sarkophagreliefs, Bd. I: Die Sarkophage mit Darstellungen aus dem Menschenleben, Teil 4: Vita privata, Berlin 1991

Amore, Agostino, Note di toponomastica cimiterale romana, in: RivAC 32, 1956, 5987

Amore, Agostino, Note agiografiche sul calendario perpetuo della Chiesa universale, in: Antonianum 39, 1964, 18-53

Amore, Agostino, I santi quattro coronati, in: Antonianum 40, 1965, 177-243

Amore, Agostino, I martiri di Roma, Rom 1975

Andreau, Jean, Fondations privées et rapports sociaux en Italie Romaine (Ier - IIIe s. ap. J.-C.), in: Ktema 2, 1977, 157-209

Andres, Friedrich, s. v. „Daimon“, in: RE, Suppl. 3, Stuttgart 1918, 267-322

Andrieu, Michel/Collomp, Paul, Fragments sur papyrus de l'anaphore de saint Marc, in: RSR 8, 1928, 489-515

Angenendt, Arnold, Missa specialis. Zugleich ein Beitrag zur Entstehung der Privatmessen, in: FMSt 17, 1983, 153-221

Apollonj Ghetti, Bruno M. u. a., Esplorazioni sotto la confessione di San Pietro in Vaticano eseguite negli anni 1940-1949, 2 Bde., Vatikanstadt 1951 
Arbeiter, Achim, Alt - St. Peter in Geschichte und Wissenschaft. Abfolge der Bauten, Rekonstruktion, Architekturprogramm, Berlin 1988

Arce, Javier, Funus imperatorum: Los funerales de los emperadores romanos, Madrid 1988

Arce, Javier, Imperial Funerals in the Later Roman Empire: Change and Continuity, in: Rituals of Power. From Late Antiquity to the Early Middle Ages, hrsg. von Frans Theuws/Janet L. Nelson, Leiden u. a. 2000, 115-129

Arnaldi, Girolamo, Rinascita, fine, reincarnazione e successive metamorfosi del Senato Romano (secoli V-XII), in: ASRSP 105, 1982, 5-56

Assmann, Aleida, Erinnerungsräume. Formen und Wandlungen des kulturellen Gedächtnisses, München 1999

Assmann, Aleida, Gedächtnis als Leitbegriff der Kulturwissenschaften, in: Kulturwissenschaften. Forschung - Praxis - Positionen, hrsg. von Lutz Musner/Gotthart Wunberg, Freiburg i. Br. 2003, 27-47

Assmann, Aleida/Friese, Heidrun, Einleitung, in: Identitäten. Erinnerung, Geschichte, Identität 3, hrsg. von Aleida Assmann/Heidrun Friese, Frankfurt a. M. 1998, 11-23

Assmann, Jan, Kollektives Gedächtnis und kulturelle Identität, in: Kultur und Gedächtnis, hrsg. von Jan Assmann/Tonio Hölscher, Frankfurt a. M. 1988, 9-19

Assmann, Jan, Das kulturelle Gedächtnis. Schrift, Erinnerung und politische Identität in frühen Hochkulturen, München 21997

Assmann, Jan, Religion und kulturelles Gedächtnis. Zehn Studien, München 2000

Auf der Maur, Hansjörg, Feste und Gedenktage der Heiligen, in: Gottesdienst der Kirche (Handbuch der Liturgiewissenschaft 6, 1. Feiern im Rhythmus der Zeit 2, 1), Regensburg 1994, 65-357

Ausbüttel, Frank M. Untersuchungen zu den Vereinen im Westen des Römischen Reiches, Kallmünz 1982

Bakker, Jan T., Living and Working with the Gods. Studies of Evidence for Private Religion and Its Material Einvironment in the City of Ostia $(100-500$ AD), Amsterdam 1994

Baldini, Antonio Ricerche sulla storia di Eunapio di Sardi. Problemi di storiografia tardopagana, Bologna 1984

Baldini, Antonio, Il filosofo Sopatro e la versione pagana della conversione di Costantino, in: Simblos. Scritti di storia antica 1, 1995, 265-286

Baldini Lippolis, Isabella, La domus tardoantica. Forme e rappresentazioni dello spazio domestico nelle città del mediterraneo, Bologna 2001

Baldovin, John F., The Urban Character of Christian Worship. The Origins, Development, and Meaning of Stational Liturgy, Rom 1987 
Barbini, Palmira M., s. v. „S. Agnetis basilica, coemeterium“, in: LTUR. Suburbium I, Rom 2001, 33-36

Barbini, Palmira M./Severini, Francesca, Risultati archeologici del nuovo saggio di scavo 1999 nella basilica cimiteriale di S. Agnese, in: Ecclesiae urbis. Atti del Congresso internazionale di studi sulle chiese di Roma (IV-X secolo), hrsg. von Federico Guidobaldi/Alessandra Guiglia Guidobaldi, Vatikanstadt 2002, Bd. 1, $757-770$

Barclay Lloyd, Joan, Krautheimer and S. Paolo fuori le mura: Architectural, Urban and Liturgical Planning in Late Fourth-Century Rome, in: Ecclesiae urbis. Atti del Congresso internazionale di studi sulle chiese di Roma (IV-X secolo), hrsg. von Federico Guidobaldi/Alessandra Guiglia Guidobaldi, Vatikanstadt 2002, Bd. 1, 1124

Bardy, Gustave, Pèlerinages à Rome vers la fin du IVe siècle, in: AB 67, 1949, 224-235

Barnes, Timothy D., The New Empire of Diocletian and Constantine, Cambridge (Mass.) 1982

Barnes, Timothy D., Statistics and the Conversion of the Roman Aristocracy, in: JRS $85,1995,135-147$

Barnes, Timothy D., The Meaning of „Tyrannus“ in the Fourth Century, in: Historiae Augustae Colloquium Barcinonense, hrsg. von Giorgio Bonamente/Marc Mayer, Bari 1996, 55-65

Barnes, Timothy D., Constantine's Speech to the „Assembly of the Saints“: Place and Date of Delivery: in: JThS n. s. 52, 2001, 26-36

Barnes, Timothy D., The Historia Augusta, Nicomachus Flavianus, and Peter the Patrician, in: CR 54, 2004, 120-124

Barnes, Timothy D./Westall, Richard W., The Conversion of the Roman Aristocracy in Prudentius' contra Symmachum, in: Phoenix 45, 1991, 50-61

Barone-Adesi, Giorgio, Dal dibattito cristiano sulla destinazione dei beni economici alla configurazione in termini di persona delle venerabiles domus destinate piis causis, in: Atti dell' Accademia Romanistica Costantiniana 9, Neapel 1993, 231-265

Bartolozzi Pasti, Gabriele, Proposte di rilettura e studi recenti sulle sopravvivenze archeologiche sotto S. Pietro in Vincoli, in: RPARA 70, 1997-1998, 235-259

Bastiaensen, Antoon A. R., Le cérémonial épistolaire des chrétiens latins. Origines et premiers développements, Nijmegen 1964

Bauer, Franz A., Stadt, Platz und Denkmal in der Spätantike. Untersuchungen zur Ausstattung des öffentlichen Raums in den spätantiken Städten Rom, Konstantinopel und Ephesos, Mainz 1996 
Bauer, Franz A., Einige weniger bekannte Platzanlagen im spätantiken Rom, in: Pratum Romanum. Richard Krautheimer zum 100. Geburtstag, hrsg. von Renate L. Colella u. a., Wiesbaden 1997, 27-54

Bauer, Franz A., Das Bild der Stadt Rom in karolingischer Zeit: der Anonymus Einsidlensis, in: RQA 92, 1997, 190-228 (zit. Bauer 1997 [a])

Bauer, Franz A., La frammentazione liturgica nella chiesa romana del primo medioevo, in: RivAC 75, 1999, 385-446

Bauer, Franz A., Überlegungen zur liturgischen Parzellierung des römischen Kirchenraums im Mittelalter, in: Bildlichkeit und Bildorte von Liturgie. Schauplätze in Spätantike, Byzanz und Mittelalter, hrsg. von Rainer Warland, Wiesbaden 2002, 75-103

Bauer, Franz A., Stadtbild und Heiligenlegenden. Die Christianisierung Ostias in der spätantiken Gedankenwelt, in: Die spätantike Stadt und ihre Christianisierung, hrsg. von Gunnar Brands/Hans-Georg Severin, Wiesbaden 2003, 43-61

Baumeister, Theofried, s. v. „Heiligenverehrung“, in: RAC 14, Stuttgart 1988, 96-150

Baus, Karl, Das Gebet der Märtyrer, in: TThZ 62, 1953, 19-32

Bendlin, Andreas, Gemeinschaft, Öffentlichkeit und Identität: Forschungsgeschichtliche Anmerkungen zu den Mustern sozialer Ordnung in Rom, in: Religiöse Vereine in der römischen Antike. Untersuchungen zu Organisation, Ritual und Raumordnung, hrsg. von Ulrike Egelhaaf-Gaiser/Alfred Schäfer, Tübingen 2002, 9-40

Bendlin, Andreas, „Eine Zusammenkunft um der religio willen ist erlaubt..."? Zu den politischen und rechtlichen Konstruktionen von (religiöser) Vergemeinschaftung in der römischen Kaiserzeit, in: Die verrechtlichte Religion. Der Öffentlichkeitsstatus von Religionsgemeinschaften, hrsg. von Hans G. Kippenberg/Gunnar F. Schuppert, Tübingen 2005, 65-107

Benko, Stephen, The Meaning of sanctorum communio, London 1964

Benn, Stanley I./Gaus, Gerald F., The Public and the Private: Concepts and Action, in: Public and Private in Social Life, hrsg. von Stanley I. Benn/Gerald F. Gaus, London 1983, 3-27

Béranger, Jean, Principatus. Etudes de notions et d'histoire politiques dans l'Antiquité gréco-romaine, Genf 1973

Berger, Rupert, Die Wendung offerre pro in der römischen Liturgie, Münster 1965

Bernand, André, s. v. „Graffito II (griechisch)“, in: RAC 12, Stuttgart 1982, 667-689

Bernstein, Frank, Ludi publici. Untersuchungen zur Entstehung und Entwicklung der öffentlichen Spiele im republikanischen Rom, Stuttgart 1998

Berschin, Walter, Biographie und Epochenstil im lateinischen Mittelalter, Bd. 1: Von der Passio Perpetuae zu den Dialogi Gregors des Großen, Stuttgart 1986 
Bertoldi, Maria E., Roma - S. Lorenzo in Lucina: gli scavi 1982-85 e le ultime ricerche, in: Atti del VII Congresso Nazionale di Archeologia Cristiana, Bd. 1, Cassino 2003, 387-389

Bertolino, Alessandro, Pannonia terra creat, tumulat Italia tellus: presenze pannoniche nell' area di S. Sebastiano, in: RivAC 73, 1997, 115-127

Bertonière, Gabriel, The Cult Center of the Martyr Hippolytus on the Via Tiburtina, Oxford 1985

Bettini, Maurizio, Familie und Verwandtschaft im antiken Rom, Frankfurt a. M. 1992 (Rom 1986)

Beyer, Klaus, Die aramäischen Inschriften aus Assur, Hatra und dem übrigen Ostmesopotamien (datiert 44 v. Chr. bis 238 n. Chr.), Göttingen 1998

Biering, Ralf/v. Hesberg, Henner, Zur Bau- und Kultgeschichte von St. Andreas apud S. Petrum. Vom Phrygianum zum Kenotaph Theodosius d. Gr.?, in: RQA 82, 1987, $145-182$

Birley, Anthony R., Religion in the Historia Augusta, in: Historiae Augustae Colloquium Parisinum, hrsg. von Giorgio Bonamente/Noël Duval, Macerata 1991, 29-51

Birley, Anthony R., The Historia Augusta and Pagan Historiography, in: Greek and Roman Historiography in Late Antiquity. Fourth to Sixth Century A.D., hrsg. von Gabriele Marasco, Leiden 2003, 127-149

Bisconti, Fabrizio, Dentro e intorno all'iconografia martiriale romana: dal „vuoto figurativo" all',,imaginario devozionale“, in: Martyrium in Multidisciplinary Perspective. Memorial Louis Reekmans, hrsg. von Mathijs Lamberigts/Peter van Deun, Löwen 1995, 247-292

Bisconti, Fabrizio, Die Dekoration der römischen Katakomben, in: Vincenzo Fiocchi Nicolai/Fabio Bisconti/Danilo Mazzoleni, Roms christliche Katakomben. Geschichte - Bilderwelt - Inschriften, Regensburg 1998, 71-145

de Blaauw, Sible L., Cultus et decor. Liturgia e architettura nella Roma tardoantica e medievale. Basilica Salvatoris, Sanctae Mariae, Sancti Petri, 2 Bde., Rom 1994

de Blaauw, Sible L., Die Krypta in stadtrömischen Kirchen: Abbild eines Pilgerziels, in: Akten des 12. Internationalen Kongresses für Christliche Archäologie, Bonn 22.28. 9. 1991, Bd. 1, Münster 1995, 559-567

Blair-Dixon, Kate, Damasus and the Fiction of Unity: The Urban Shrines of Saint Laurence, in: Ecclesiae urbis. Atti del Congresso internazionale di studi sulle chiese di Roma (IV-X secolo), hrsg. von Federico Guidobaldi/Alessandra Guiglia Guidobaldi, Vatikanstadt 2002, Bd. 1, 333-352

Bleckmann, Bruno, Die Chronik des Johannes Zonaras und eine pagane Quelle zur Geschichte Konstantins, in: Historia 40, 1991, 343-365 
Bleckmann, Bruno, Die Reichskrise des III. Jahrhunderts in der spätantiken und byzantinischen Geschichtsschreibung. Untersuchungen $\mathrm{zu}$ den nachdionischen Quellen der Chronik des Johannes Zonaras, München 1992

Bleckmann, Bruno, Bemerkungen zu den Annales des Nicomachus Flavianus, in: Historia 44, 1995, 83-99

Bleckmann, Bruno, Constantin und die Donaubarbaren. Ideologische Auseinandersetzungen um die Sieghaftigkeit Constantins, in: JbAC 38, 1995, 38-66 (zit. Bleckmann 1995 [a])

Bleckmann, Bruno, Überlegungen zur Enmannschen Kaisergeschichte und zur Formung historischer Traditionen in tetrarchischer und konstantinischer Zeit, in: Historiae Augustae Colloquium Bonnense, hrsg. von Giorgio Bonamente/Klaus Rosen, Bari 1997, 11-37

Bleicken, Jochen, Die Verfassung der Römischen Republik. Grundlagen und Entwicklung, Paderborn 71995

Blockley, Roger C., The Fragmentary Classicising Historians of the Later Roman Empire. Eunapius, Olympiodorus, Priscus and Malchus, Bd. 1, Liverpool 1981

Blösel, Wolfgang, Die Geschichte des Begriffes mos maiorum von den Anfängen bis zu Cicero, in: Mos maiorum. Untersuchungen zu den Formen der Identitätsstiftung und Stabilisierung in der römischen Republik, hrsg. von Bernhard Linke/Michael Stemmler, Stuttgart 2000, 25-97

Boccaccini, Gabriele, Il tema della memoria nell'ebraismo e nel giudaismo antico, in: Henoch 7, 1985, 165-192

Bodel, John P., Monumental Villas and Villa Monuments, in: JRA 10, 1997, 5-45

de Boer, Pieter A. H., Gedenken und Gedächtnis in der Welt des Alten Testaments, Stuttgart 1962

Bolkestein, Hendrik, Wohltätigkeit und Armenspflege im vorchristlichen Altertum. Ein Beitrag zum Problem „Moral und Gesellschaft“", Utrecht 1939

Bollmann, Beate, Römische Vereinshäuser. Untersuchungen zu den Scholae der römischen Berufs-, Kult, und Augustalen-Kollegien in Italien, Mainz 1998

Bonanni, Alessandro, La basilica di S. Susanna a Roma. Indagini topografiche e nuove scoperte archeologiche, in: Akten des 12. Internationalen Kongresses für Christliche Archäologie, Bonn 22.-28. 9. 1991, Bd. 1, Münster 1995, 586-589

Borg, Barbara/Witschel, Christian, Veränderungen im Repräsentationsverhalten der römischen Eliten während des 3. Jhs. n. Chr., in: Inschriftliche Denkmäler als Medien der Selbstdarstellung in der römischen Welt, hrsg. von Géza Alföldy/Silvio Panciera, Stuttgart 2001, 47-120

Borgolte, Michael, Freigelassene im Dienst der Memoria. Kulttradition und Kultwandel zwischen Antike und Mittelalter, in: FMSt 17, 1983, 234-250 
Borgolte, Michael, Die Stiftungen des Mittelalters in rechts- und sozialhistorischer Sicht, in: ZSRG.K 74, 1988, 71-94

Borgolte, Michael, „Totale Geschichte“ des Mittelalters? Das Beispiel der Stiftungen, Berlin 1993

Borgolte, Michael, Petrusnachfolge und Kaiserimitation. Die Grablegen der Päpste, ihre Genese und Traditionsbildung, Göttingen 21995

Borgolte, Michael, Memoria. Zwischenbilanz eines Mittelalterprojekts, in: ZfG 46, 1998, 197-210

Borgolte, Michael, Zur Lage der deutschen Memoria-Forschung, in: ders., Memoria. Ricordare e dimenticare nella cultura del medioevo - Memoria. Erinnern und Vergessen in der Kultur des Mittelalters, hrsg. von Michael Borgolte u. a., Bologna u. Berlin 2005, 21-28

Borgolte, Michael, Einleitung, in: Stiftungen in Christentum, Judentum und Islam vor der Moderne. Auf der Suche nach ihren Gemeinsamkeiten und Unterschieden in religiösen Grundlagen, praktischen Zwecken und historischen Transformationen, hrsg. von Michael Borgolte, Berlin 2005, 9-21 (zit. Borgolte 2005 [a])

Borsdorf, Ulrich/Grütter, H. Theodor, Einleitung, in: Orte der Erinnerung. Denkmal, Gedenkstätte, Museum, hrsg. von Ulrich Borsdorf/H. Theodor Grütter, Frankfurt a. M./New York 1999, 1-10

Bourdieu, Pierre, Die feinen Unterschiede. Kritik der gesellschaftlichen Urteilskraft, Frankfurt a. M. 1982

Bourdieu, Pierre, Sozialer Raum und Klassen. Leçon sur la leçon. Zwei Vorlesungen, Frankfurt a. M. 1985

Bowersock, Glen W., Martyrdom and Rome, Cambridge 1995

Bowersock, Glen W., Peter and Constantine, in: Humana sapit. Études d'antiquité tardive offertes à Lellia Cracco Ruggini, hrsg. von Jean-Michel Carrié/Rita Lizzi Testa, Turnhout 2002, 209-217

Bowes, Kimberly, Personal Devotions and Private Chapels, in: A People's History of Christianity, Bd. 2: Late Ancient Christianity, hrsg. von Virginia Burrus, Minneapolis $2005,188-210$

Bradbury, Scott, Constantine and Anti-Pagan Legislation in the Forth Century, in: CPh 89, 1994, 120-139

Brandenburg, Hugo, Das Grab des Papstes Cornelius und die Lucinaregion der Calixtus-Katakombe, in: JbAC 11/12, 1968-1969, 42-54

Brandenburg, Hugo, Roms frühchristliche Basiliken des 4. Jahrhunderts, München 1979 
Brandenburg, Hugo, Überlegungen zu Ursprung und Entstehung der Katakomben Roms, in: Vivarium. Festschrift Theodor Klauser zum 90. Geburtstag, Münster 1984, 11-49

Brandenburg, Hugo, Die konstantinischen Kirchen in Rom. Staatstragender Kult und Herrscherkult zwischen Tradition und Neuerung, in: MOUSIKOS ANER. Festschrift für Max Wegner zum 90. Geburtstag, hrsg. von Oliver Brehm/Sascha Klie, Bonn 1992, 27-58

Brandenburg, Hugo, Coemeterium. Der Wandel des Bestattungswesens als Zeichen des Kulturumbruchs der Spätantike, in: Laverna 5, 1994, 206-232

Brandenburg, Hugo, Altar und Grab. Zu einem Problem des Märtyrerkultes im 4. und 5. Jh., in: Martyrium in Multidisciplinary Perspective. Memorial Louis Reekmans, hrsg. von Mathijs Lamberigts/Peter van Deun, Löwen 1995, 71-98

Brandenburg, Hugo, Kirchenbau und Liturgie. Überlegungen zum Verhältnis von architektonischer Gestalt und Zweckbestimmung des frühchristlichen Kultbaus im 4. und 5. Jh., in: Divitiae Aegypti. Koptologische und verwandte Studien zu Ehren von Martin Krause, hrsg. von C. Fluck u. a., Wiesbaden 1995, 36-76 (zit. Brandenburg 1995 [a])

Brandenburg, Hugo, Die Kirche S. Stefano Rotondo in Rom. Bautypologie und Architektursymbolik in der spätantiken und frühchristlichen Architektur, Berlin/New York 1998

Brandenburg, Hugo, Die frühchristlichen Kirchen Roms vom 4. bis zum 7. Jahrhundert. Der Beginn der abendländischen Kirchenbaukunst, Regensburg 2004

Brandenburg, Hugo, s. v. „Constantiae ecclesia, mausoleum“, in: LTUR. Suburbium II, Rom 2004, 140-147 (zit. Brandenburg 2004 [a])

Brändle, Rudolf, Petrus und Paulus als nova sidera, in: ThZ 47, 1992, 207-217

Brandt, Hartwin, Konstantin der Große. Der erste christliche Kaiser. Eine Biographie, München 2006

Braudel, Fernand, Das Mittelmeer und die mediterrane Welt in der Epoche Philipps II., 3 Bde., Frankfurt a. M. 1990 (Paris 41979)

Braun, Joseph, Der christliche Altar in seiner geschichtlichen Entwicklung, 2 Bde., München 1924

Brelich, Angelo, Aspetti della morte nelle iscrizioni sepolcrali dell'Impero Romano, Budapest 1937

Bremmer, Jan M., The Passion of Perpetua and the Development of Early Christian Afterlife, in: NedThT 54, 2000, 97-111

Brenk, Beat, Microstoria sotto la Chiesa dei SS. Giovanni e Paolo: la cristianizzazione di una casa privata, in: RIA, ser. III, 18, 1995, 169-205 
Brenk, Beat, Die Christianisierung der spätrömischen Welt. Stadt, Land, Haus, Kirche und Kloster in frühchristlicher Zeit, Wiesbaden 2003

Brennecke, Hanns C., Hilarius von Poitiers und die Bischofsopposition gegen Konstantius II. Untersuchungen zur dritten Phase des arianischen Streites (337361), Berlin/New York 1984

Brent, Allen, Hippolytus and the Roman Church in the Third Century. Communities in Tension before the Emergence of a Monarch-Bishop, Leiden 1995

Bringmann, Klaus, Christentum und römischer Staat im ersten und zweiten Jahrhundert n. Chr., in: GWU 29, 1978, 1-18

Bringmann, Klaus, Die konstantinische Wende. Zum Verhältnis von politischer und religiöser Motivation, in: HZ 260, 1995, 21-47

Brown, Donald F., Temples of Rome as Coin Types, New York 1940

Brown, Peter, Aspects of the Christianization of the Roman Aristocracy, in: JRS 51, 1961, 1-11 (leicht aktualisierter ND in: ders., Religion and Society in the Age of Saint Augustine, London 1972, 161-182; danach zit. Brown 1961 [1972])

Brown, Peter, Pelagius and His Supporters: Aims and Environment, in: JThS, n. s. 19, 1968, 93-114

Brown, Peter, Die letzten Heiden. Eine kleine Geschichte der Spätantike, Frankfurt a. M. 1995 (erweiterte Übersetzung von: The Making of Late Antiquity, Cambridge [Mass.] 1978)

Brown, Peter, The Cult of the Saints. Its Rise and Function in Latin Christianity, Chicago 1981

Brown, Peter, Della „plebs romana“ alla „plebs Dei“: aspetti della cristianizzatione di Roma, in: P. Brown/L. Cracco Ruggini/M. Mazza, Governanti e intellettuali: popolo di Roma e popolo di Dio (I-VI secolo), Turin 1982, 123-145

Brown, Peter, Power and Persuasion in Late Antiquity. Towards a Christian Empire, Madison 1992

Brown, Peter, Authority and the Sacred. Aspects of the Christianisation of the Roman World, Cambridge 1995

Brown, Peter, Poverty and Leadership in the Later Roman Empire, Hanover 2002

Brox, Norbert, s. v. „Häresie“, in: RAC 13, Stuttgart 1986, 248-297

Brox, Norbert, Die reichen und die armen Christen. Eine Parabel aus der altrömischen Kirche, in: Biotope der Hoffnung. Zu Christentum und Kirche heute, Ludwig Kaufmann zu Ehren, hrsg. von Nikolaus Klein u. a., Olten/Freiburg i. Br. 1988, 224-229

Bruck, Eberhard F., Über römisches Recht im Rahmen der Kulturgeschichte, Berlin u. a. 1954 
Bruck, Eberhard F., Kirchenväter und soziales Erbrecht. Wanderungen religiöser Ideen durch die Rechte der östlichen und westlichen Welt, Berlin u. a. 1956

Bruggisser, Philippe, Symmaque ou le rituel épistolaire de l'amitié littéraire. Recherches sur le premier livre de la correspondance, Fribourg 1993

Bruun, Patrick, The Consecration Coins of Constantine the Great, in: Arctos 1, 1954, 19-31

de Bruyne, Luciano, L'antica serie di ritratti papali della basilica di S. Paolo fuori le mura, Rom 1934

Buchowiecki, Walther, Handbuch der Kirchen Roms. Der römische Sakralbau in Geschichte und Kunst von der altchristlichen Zeit bis zur Gegenwart, 4 Bde., Wien 1967-1997

Bundy, David D., The „Acts of Saint Gallicanus“: A Study of the Structural Relations, in: Byzantion 57, 1987, 12-31

Burgess, Richard W., A Common Source for Jerome, Eutropius, Festus, Ammianus, and the Epitome de Caesaribus between 358 and 378, along with Further Thoughts on the Date and Nature of the Kaisergeschichte, in: CPh 100, 2005, 166-192

Burke, Peter, Geschichte als soziales Gedächtnis, in: Mnemosyne. Formen und Funktionen der kulturellen Erinnerung, hrsg. von Aleida Assmann/Dietrich Harth, Frankfurt a. M. 1991, 289-304 (uspr. History and Social Memory, in: Memory. History, Culture and Mind, Oxford 1989, 97-113)

Buschhausen, Helmut, Die spätrömischen Metallscrinia und frühchristlichen Reliquiare, Teil 1: Katalog, Wien 1971

Caillet, Jean-Pierre, L'évergétisme monumental chrétien en Italie et à ses marges d'après l'épigraphie des pavements de mosaïque (IVe-VIIe s.), Rom 1993

Callam, Daniel, The Frequency of Mass in the Latin Church ca. 400, in: ThS 45, 1984, 613-650

Calderone, Salvatore, Costantinopoli: la ,seconda Roma“, in: Storia di Roma, Bd. 3, 1: L'età tardoantica. Crisi e trasformazioni, hrsg. von Andrea Carandini u. a., Turin 1993, 723-749

Cameron, Alan, Filocalus and Melania, in: CPh 87, 1992, 140-144

Cameron, Alan, The Last Pagans of Rome, in: The Transformations of urbs Roma in Late Antiquity, hrsg. von William V. Harris, Rom 1999, 109-121

Cameron, Alan, Petronius Probus, Aemilius Probus and the Transmission of Nepos: A Note on Late Roman Calligraphers, in: Humana sapit. Études d'antiquité tardive offertes à Lellia Cracco Ruggini, hrsg. von Jean-Michel Carrié/Rita Lizzi Testa, Turnhout 2002, 121-130

Cameron, Averil, The Mediterranean World in Late Antiquity, AD 395-600, London/ New York 1993 
Cameron, Averil, The Reign of Constantine, A. D. 306-337, in: CAH 12: The Crisis of Empire, A. D. 193-337, Cambridge 22005, 90-109

Caner, Daniel, Wandering, Begging Monks. Spiritual Authority and the Promotion of Monasticism in Late Antiquity, Berkeley u. a. 2002

Cantino Wataghin, Gisella, The Ideology of Urban Burials, in: The Idea and Ideal of the Town between Late Antiquity and the Early Middle Ages, hrsg. von Gian P. Brogiolo/Bryan Ward-Perkins, Leiden 1999, 147-180

Capelle, Bernard, Problèmes du Communicantes de la messe, in: RivLi 40, 1953, 187-195 (ND in: ders., Travaux liturgiques 2, Löwen 1962, 269-275)

Carandini, Andrea/Ricci, Andreina/de Vos, Mariette, Filosofiana. La villa di Piazza Armerina. Immagine di un aristocrato romano al tempo di Costantino, Palermo 1982

Carletti, Carlo, Iscrizioni cristiane inedite del cimitero di Bassilla „ad Hermetem“, Vatikanstadt 1976

Carletti, Carlo, „Epigrafia cristiana“, „epigrafia dei cristiani“: alle origini della terza età dell'epigrafia, in: La terza età dell'epigrafia, Colloquio AIEGL - Borhesi, Bologna, Oktober 1986, hrsg. von Angela Donati, Faenza 1988, 115-135

Carletti, Carlo, Storia e topografia della catacomba di Commodilla, in: Johannes G. Deckers/Gabriele Miethke/Albrecht Weiland, Die Katakombe „Commodilla“. Repertorium der Malereien, Bd. 1, Vatikanstadt 1994, 3-27

Carletti, Carlo, Nascita e sviluppo del formulario epigrafico cristiano: prassi e idelogia, in: Le iscrizioni dei cristiani in Vaticano: materiali e contributi scientifici per una mostra epigrafica (Inscriptiones Sanctae Sedis, Bd. 2), hrsg. von Ivan DiStefano Manzella, Vatikanstadt 1997, 143-165

Carmassi, Patrizia, La prima redazione del Liber Pontificalis nel quadro delle fonti contemporanee. Osservazioni in margine alla vita di Simmaco, in: Atti del colloquio internazionale „Il Liber Pontificalis e la storia materiale” (MNHIR 60/61 [20012002]), hrsg. von Herman Geertman, Rom 2003, 235-266

Caspar, Erich, Geschichte des Papsttums von den Anfängen bis zur Höhe der Weltherrschaft, 2 Bde., Tübingen 1930/1933

Cecchelli, Carlo, Monumenti cristiano-eretici di Roma, Rom o. J. (1944)

Cecchelli Trinci, Margherita, Osservazioni sul complesso della domus Celimontana dei SS. Giovanni e Paolo, in: Atti del IX Congresso Internazionale di Archeologia Cristiana, Rom, 21.-27. 9. 1975, Bd. 1, Vatikanstadt 1978, 551-562

Cecchelli Trinci, Margherita, Intorno ai complessi battesimali di S. Pietro in Vaticano e di S. Agnese sulla via Nomentana, in: QIASA 3, 1982-1983, 181-199

Cecchelli, Margherita, Note sui „titoli“ romani, in: ArchClass 38, 1985, 293-305 
Cecchelli, Margherita, „Spazio cristiano“ e monumenti eretici in Roma, in: Atti del VI Congresso nazionale di Archeologia Cristiana, Ancona 1985-1986, 287-296

Cecchelli, Margherita, Dati da scavi recenti di monumenti cristiani. Sintesi relativa a diverse indagini in corso, in: MEFRM 111, 1, 1999, 227-251

Cecchelli, Margherita, L'edificio di culto tra il III e l'VIII secolo, in: Aurea Roma. Dalla città pagana alla città cristiana, hrsg. von Serena Ensoli/Eugenio La Rocca, Rom 2000, 179-183

Cecchelli, Margherita, Spazio cristiano: l'edificio di culto, tipologia ed evoluzione, in: La comunità cristiana di Roma. La sua vita e la sua cultura dalle origini all'alto medioevo, hrsg. von Letizia Pani Ermini/Paolo Siniscalco, Vatikanstadt 2000, 421438 (zit. Cecchelli 2000 [a])

Cecchelli, Margherita, Interventi edilizi di papa Simmaco, in: Il papato di San Simmaco (498-514), hrsg. von Giampaolo Mele/Natalino Spaccapelo, Cagliari 2000, 111-128 (zit. Cecchelli 2000 [b])

Cecchelli, Margherita, Le strutture murarie di Roma tra IV e VII secolo, in: Materiali e tecniche dell'edilizia paleocristiana a Roma, hrsg. von Margherita Cecchelli, Rom 2001, 11-102

Cecconi, Giovanni A., Governo imperiale e élites dirigenti nell'Italia tardoantica. Problemi di storia politico-amministrativa (270-476 d. C.), Como 1994

Cerrito, Alessandra, Sull'oratorio di S. Felicita presso le terme di Traiano a Roma, in: Domum tuam dilexi. Miscellanea in onore di Aldo Nestori, hrsg. von Federico Guidobaldi, Vatikanstadt 1998, 155-184

Cerrito, Alessandra, Oratori ed edifici di culto minori di Roma tra il IV secolo e i primi decenni del V, in: Ecclesiae urbis. Atti del Congresso internazionale di studi sulle chiese di Roma (IV-X secolo), hrsg. von Federico Guidobaldi/Alessandra Guiglia Guidobaldi, Vatikanstadt 2002, Bd. 1, 397-418

Chadwick, Henry, St. Peter and St. Paul in Rome: The Problem of the Memoria Apostolorum ad Catacumbas, in: JThS, n. s., 8, 1957, 31-52

Chadwick, Henry, Pope Damasus and the Peculiar Claim of Rome to St. Peter and St. Paul, in: Neotestamentica et Patristica. Eine Freundesgabe, Oscar Cullmann überreicht, Leiden 1962, 313-318 (ND in: ders., History and Thought of the Early Church, London 1982, nr. 3)

Champlin, Edward, Saint Gallicanus (Consul 317), in: Phoenix 36, 1982, 71-76

Champlin, Edward, Final Judgements. Duty and Emotion in Roman Wills, 200 B.C. A.D. 250, Berkeley 1991

Chantraine, Heinrich, Das Schisma von 418/419 und das Eingreifen der kaiserlichen Gewalt in die römische Bischofswahl, in: Alte Geschichte und Wissenschaftsgeschichte. Festschrift für Karl Christ zum 65. Geburtstag, hrsg. von Peter Kneissl/Volker Losemann, Darmstadt 1988, 79-94 
Chapman, John, On the decretum Gelasianum de libris recipiendis et non recipiendis, in: RBen 30, 1913, 187-207, 315-333

Chastagnol, André, La Préfecture urbaine à Rome sous le Bas-Empire, Paris 1960

Chastagnol, André, Les fastes de la Préfecture de Rome au Bas-Empire, Paris 1962

Chastagnol, André, Le sénat sous le règne d'Odoacre. Recherche sur l'épigraphie du Colisée au Ve siècle, Bonn 1966

Chastagnol, André, Sur quelques documents relatifs à la basilique de Saint-Paul-horsles-Murs, in: Mélanges d'archéologie et d'histoire offerts à André Piganiol, hrsg. von Raymond Chevallier, Bd. 1, Paris 1966, 421-437 (erweiterter ND, in: André Chastagnol, Aspects de l'antiquité tardive, Rom 1994, 309-327; danach zit. Chastagnol 1966 [1994])

Chastagnol, André, Un chapitre négligé de l'épigraphie latine: la titulature des empereurs morts, in: REL 62, 1984, 275-287

Chastagnol, André, Aspects concrets et cadre topographique des fêtes décennales des empereurs à Rome, in: L'urbs. Espace urbain et histoire (Ier siècle av. J.-C. - IIIe siècle ap. J.-C.), Rom 1987, 491-507

Chastagnol, André, Les inscriptions des monuments inaugurés lors des fêtes imperiales, in: MEFRA 100, 1988, 13-26

Chausson, François, Une sœur de Constantin: Anastasia, in: Humana sapit. Études d'antiquité tardive offertes à Lellia Cracco Ruggini, hrsg. von Jean-Michel Carrié/ Rita Lizzi Testa, Turnhout 2002, 131-155

Chavasse, Antoine, Le sacramentaire gélasien (Vaticanus Regensis 316). Sacramentaire presbytéral en usage dans les titres romains au VIIe siècle, Tournai 1958

Chavasse, Antoine, Le sacramentaire, dit Léonien, conservé par le Veronensis LXXXV (80), in: SE 27, 1984, 151-190

Childs, Brevard S., Memory and Tradition in Israel, London 1962

Clark, Elizabeth A., The Life of Melania the Younger. Introduction, Translation and Commentary, New York 1984

Clark, Francis, The ,Gregorian’ Dialogues and the Origins of Benedictine Monasticism, Leiden 2003

Clark, Gillian, Translating Relics: Victricius of Rouen and Fourth-Century Debate, in: Early Medieval Europe 10, 2001, 161-176

Clark, Gillian, Christianity and Roman Society, Cambridge 2004

Clarke, John R., The Houses of Roman Italy, 100 B.C. - A.D. 250. Ritual, Space, and Decoration, Berkeley 1991

Clauss, Manfred, Kaiser und Gott. Herrscherkult im römischen Reich, Stuttgart/ Leipzig 1999 
Clerici, Luigi, Einsammlung der Zerstreuten. Liturgiegeschichtliche Untersuchungen zur Vor- und Nachgeschichte der Fürbitte für die Kirche in Didache 9, 4 und 10, 5, Münster 1966

Coarelli, Filippo, L'urbs e il suburbio, in: Società romana e impero tardoantico, Bd. 2: Roma. Politica, economia, paesaggio urbano, hrsg. von Andrea Giardina, Rom/Bari 1986, $1-58$ u. 395-412

Coarelli, Filippo, Gli spazi della vita sociale, in: Roma imperiale. Una metropoli antica, hrsg. von Elio Lo Cascio, Rom 2000, 221-247

Colafranceso Carletti, Pasqua, L'area semantica di pax nella poesia tardo antica, in: VetChr 32, 1995, 269-292

Colella, Renate L., Hagiographie und Kirchenpolitik - Stephanus und Laurentius in Rom, in: Pratum Romanum. Richard Krautheimer zum 100. Geburtstag, hrsg. von Renate L. Colella u. a., Wiesbaden 1997, 75-96

Colini, Antonio M., Horti Spei veteris, palatium Sessorianum, in: MPARA 8, 3, 1955, 137 177

Colli, Donato, Il palazzo Sessoriano nell'area archeologica di S. Croce in Gerusalemme: ultima sede imperiale a Roma?, in: MEFRA 108, 1996, 771-815

Colpe, Carsten/Dassmann, Ernst/Engemann, Josef/Habermehl, Peter/Hoheisel, Karl, s. v. ,Jenseits (Jenseitsvorstellungen)“, in: RAC 17, Stuttgart 1996, 246-407

Compostella, Carla, Banchetti pubblici e banchetti privati nell'iconografia funeraria Romana del I secolo d. C., in: MEFRA 104, 2, 1992, 659-689

Connerton, Paul, How Societies Remember, Cambridge 1989

Constable, Giles, The Commemoration of the Dead in the Early Middle Ages, in: Early Medieval Rome and the Christian West. Essays in Honour of Donald A. Bullough, hrsg. von Julia M. H. Smith, Leiden 2000, 169-195

Cooley, Alison E., Inscribing History at Rome, in: The Afterlife of Inscriptions. Reusing, Rediscovering, Reinventing and Revitalizing Ancient Inscriptions, hrsg. von Alison E. Cooley, London 2000, 7-20

Cooper, Kate, The Martyr, the matrona and the Bishop: The Matron Lucina and the Politics of Martyr Cult in Fifth- and Sixth-Century Rome, in: Early Medieval Europe $8,1999,297-317$

Cornelißen, Christoph, Was heißt Erinnerungskultur? Begriff - Methoden - Perspektiven, in: GWU 54, 2003, 548-563

Coşkun, Altay, Der Praefect Maximus, der Jude Isaak und der Strafprozeß gegen Bischof Damasus von Rom, in: JbAC 46, 2003, 17-44, bes. 18-27

Costambeys, Marios, Burial Topography and the Power of the Church in Fifth- and Sixth-Century Rome, in: PBSR 69, 2001, 169-189 
Costambeys, Marios, The Culture and Practice of Burial in and around Rome in the Sixth Century, in: Ecclesiae urbis. Atti del Congresso internazionale di studi sulle chiese di Roma (IV-X secolo), hrsg. von Federico Guidobaldi/Alessandra Guiglia Guidobaldi, Vatikanstadt 2002, Bd. 1, 721-731

Coyle, J. Kevin, Memoriae apostolorum: The Tombs of and Remains of the Apostles at Rome as Symbols in Augustine's Thought, in: Pietro e Paolo. Il loro rapporto con Roma nelle testimonianze antiche, Rom 2001, 473-487

Cracco Ruggini, Lellia, Apoteosi e politica senatoria nel IV secolo d. C.: il dittico dei Simmachi al British Museum, in: RSIt 89, 1977, 425-489

Cracco Ruggini, Lellia, Gli Anicii a Roma e in provincia, in: MEFRM 100, 1988, 69-85

Cracco Ruggini, Lellia, Elagabalo, Costantino e i culti „siriaci“ nella Historia Augusta, in: Historiae Augustae Colloquium Parisinum, hrsg. von Giorgio Bonamente/Noël Duval, Macerata 1991, 123-146

Cracco Ruggini, Lellia, Spazi urbani clientelari e caritativi, in: La Rome impériale. Démographie et logistique, hrsg. von Catherine Virlouvet, Rom 1997, 157-191

Cracco Ruggini, Lellia, Pietro e Paolo a Roma nel tardoantico e le traditizioni dell'urbs arcaica, in: Pietro e Paolo. Il loro rapporto con Roma nelle testimonianze antiche, Rom 2001, 373-392

Cracco Ruggini, Lellia, Rome in Late Antiquity: Clientship, Urban Topography, and Prosopography, in: CPh 98, 2003, 366-382

Cullhed, Mats, Conservator urbis suae. Studies in the Politics and Propaganda of the Emperor Maxentius, Stockholm 1994

Cuming, Geoffrey J., The Liturgy of St Mark, Rom 1990

Curran, John R., Pagan City and Christian Capital. Rome in the Fourth Century, Oxford 2000

Cuscito, Giuseppe, Il culto di S. Crisogono fra Aquileia e Roma, in: Aquileia e Roma (AnAl 30), Udine 1987, 255-274

Cuscito, Giuseppe, Martiri cristiani ad Aquileia e in Istria. Documenti archeologici e questioni agiografiche, Udine 1992

Dagron, Gilbert, Les moines et la ville: Le monachisme à Constantinople jusqu'au concile de Chalcédoine (451), in: TMCB 4, 1970, 229-276

Dagron, Gilbert, Naissance d'une capitale. Constantinople et ses institutions de 330 à 451, Paris 1974

Daguet-Gagey, Anne, Les opera publica à Rome (180-305 ap. J.-C.), Paris 1997

d'Alès, Adhémar, Les deux vies de Sainte Mélanie le Jeune, in: AB 25, 1906, 401-450

Damir-Geilsdorf, Sabine/Hendrich, Béatrice, Orientierungsleistungen räumlicher Strukturen und Erinnerung. Heuristische Potenziale einer Verknüpfung der 
Konzepte Raum, mental maps und Erinnerung, in: Mental Maps - Raum Erinnerung. Kulturwissenschaftliche Zugänge zum Verhältnis von Raum und Erinnerung, hrsg. von Sabine Damir-Geilsdorf u. a., Münster 2005, 25-48

Daniel, Ute, Kompendium Kulturgeschichte. Theorien, Praxis, Schlüsselwörter, Frankfurt a. M. 2001

d'Arms, John H., Memory, Money, and Status at Misenum: Three New Inscriptions from the collegium of the Augustales, in: JRS 90, 2000, 126-144

Ernst Dassmann, Sündenvergebung durch Taufe, Buße und Martyrerfürbitte in den Zeugnissen frühchristlicher Frömmigkeit und Kunst, Münster 1973

Davies, Penelope J. E., Death and the Emperor. Roman Imperial Funerary Monuments from Augustus to Marcus Aurelius, Cambridge 2000

Davis-Weyer, Caecilia/Emerick, Judson J., The Early Sixth-Century Frescoes at S. Martino ai Monti in Rome, in: Römisches Jahrbuch für Kunstgeschichte 21, 1984, $1-60$

Deckers, Johannes G., Wie genau ist eine Katakombe zu datieren? Das Beispiel SS. Marcellino e Pietro, in: Memoriam sanctorum venerantes. Miscellanea in onore di Victor Saxer, Vatikanstadt 1992, 217-238

Deichmann, Friedrich W., Die Lage der constantinischen Basilika der Heiligen Agnes an der Via Nomentana, in: RivAC 22, 1946, 213-234

Deichmann, Friedrich W. Märtyrerbasilika, Martyrion, Memoria und Altargrab, in: MDAI(R) 77, 1970, 144-169

Deichmann, Friedrich W., Ravenna. Hauptstadt des spätantiken Abendlandes, 4 Bde., Stuttgart 1969-1989

Deichmann, Friedrich W./Tschira, Arnold, Das Mausoleum der Kaiserin Helena und die Basilika der Heiligen Marcellinus und Petrus an der Via Labicana vor Rom, in: Jahrbuch des Deutschen Archäologischen Instituts 72, 1957, 44-110

Delehaye, Hippolyte, L'amphithéatre flavien et ses environs dans les textes hagiographiques, in: AB 16, 1897, 209-252

Delehaye, Hippolyte, Rez. Dufourcq 1900-1910/1988, Bd. 1, in: AB 19, 1900, 444447

Delehaye, Hippolyte, Rez. Urbain 1901, in: AB 21, 1902, 89-93

Delehaye, Hippolyte, Les légendes hagiographiques, Brüssel 1905

Delehaye, Hippolyte, Saints de Thrace et de Mésie, in: AB 31, 1912, 161-300

Delehaye, Hippolyte, Le culte des Quatre Couronnés à Rome, in: AB 32, 1913, 63-71

Delehaye, Hippolyte, Sanctus. Essai sur le culte des saints dans l'antiquité, Brüssel 1927 
Delehaye, Hippolyte, L'hagiographie ancienne de Ravenne, in: AB 47, 1929, 5-30

Delehaye, Hippolyte, Loca sanctorum, in: AB 48, 1930, 5-64

Delehaye, Hippolyte, Les origines du culte des martyrs, Brüssel ${ }^{2} 1933$

Delehaye, Hippolyte, Récherches sur le légendier romain, in: AB 51, 1933, 34-98 (zit. Delehaye 1933 [a])

Delehaye, Hippolyte, Cinq leçons sur la méthode hagiographique, Brüssel 1934

Delehaye, Hippolyte, Étude sur le légendier romain. Les saints de novembre et de décembre, Brüssel 1936

Delehaye, Hippolyte, Les passions des martyrs et les genres littéraires, Brüssel ${ }^{2} 1966$

Delmaire, Roland, Largesses sacrées et res privata. L'aerarium impérial et son administration du IVe au VIe siècle, Rom 1989

Dendy, David R., The Use of Lights in Christian Worship, London 1959

Deneken, F., s. v. „Heros“, in: Ausführliches Lexikon der griechischen und römischen Mythologie, hrsg. von Wilhelm H. Roscher, Bd. I, 2, Leipzig 1886-1890, 2441-2589

de Rossi, Giovanni B., La Roma sotteranea cristiana, 3 Bde., Rom 1864-1877

de Rossi, Giovanni B., I monumenti del secolo quarto spettanti alla chiesa di s. Pudenziana, in: BAC, ser. 1, 5, 1867, 49-60

de Rossi, Giovanni B., Di tre antichi edifici componenti la chiesa dei ss. Cosma e Damiano; e di una contigua chiesa dedicata agli apostoli Pietro e Paolo, in: BAC, ser. 1, 5, 1867, 61-71 (zit. de Rossi 1867 [a])

de Rossi, Giovanni B., I monumenti scoperti sotto la basilica di S. Clemente studiati nella loro successione stratigrafica e cronologica, in: BAC, ser. 2, 1, 1870, 129-168

de Rossi, Giovanni B., Elogio damasiano del celebre Ippolito martire sepolto pressa la via Tiburtina, in: BAC, ser. 3, 6, 1881, 26-54

de Rossi, Giovanni B., Il cimitero di S. Ippolito presso la via Tiburtina e la sua principale cripta storica ora dissepolta, in: BAC, ser. 4, 1, 1882, 9-76

de Rossi, Giovanni B., Le recenti escavazioni nel piano inferiore del cimitero di Priscilla, in: BAC, ser. 4, 3, 1884-1885, 59-85

de Ruggiero, Ettore, Lo stato e le opere pubbliche in Roma antica, Turin 1925

de Santis, Paola, Elementi di corrredo nei sepolcri delle catacombe romane: l'esempio della regione di Leone e della galleria $\mathrm{Bb}$ nella catacomba di Commodilla, in: VetChr 31, 1994, 23-51

de Spirito, Giuseppe, Ursino e Damaso - una nota, in: Peregrina curiositas. Eine Reise durch den orbis antiquus. Zu Ehren von Dirk van Damme, hrsg. von Andreas Kessler u. a., Göttingen 1994, 263-274 
de Spirito, Giuseppe, s. v. „domus: Lucina“, in: LTUR II, Rom 1995, 133

de Spirito, Giuseppe, s. v. „Lucina, titulus“, in: LTUR III, Rom 1996, $192 \mathrm{f}$.

Deshusses, Jean, Le sacramentaire grégorien: ses principales formes d'après les plus anciens manuscrits, 3 Bde., Fribourg 21992

Diefenbach, Steffen, Jenseits der „Sorge um sich“. Zur Folter von Philosophen und Märtyrern in der römischen Kaiserzeit, in: Das Quälen des Körpers. Eine historische Anthropologie der Folter, hrsg. von Peter Burschel u. a., Köln u. a. 2000, 99-131

Diefenbach, Steffen, Zwischen Liturgie und civilitas. Konstantinopel im 5. Jahrhundert und die Etablierung eines städtischen Kaisertums, in: Bildlichkeit und Bildorte von Liturgie. Schauplätze in Spätantike, Byzanz und Mittelalter, hrsg. von Rainer Warland, Wiesbaden 2002, 21-49

Diefenbach, Steffen, Beobachtungen zum antiken Rom im hohen Mittelalter: Städtische Topographie als Herrschafts- und Erinnerungsraum, in: RQA 97, 2002, 40-88 (zit. Diefenbach 2002 [a])

Diefenbach, Steffen, Urbs und ecclesia. Bezugspunkte kollektiver Heiligenerinnerung im Rom des Bischofs Damasus (366-384), erscheint in: Historische Erinnerung im städtischen Raum: Rom in der Spätantike, hrsg. von Ralf Behrwald/Christian Witschel, Stuttgart 2008 (zit. Diefenbach [i. Druck])

Diem, Albrecht, Das monastische Experiment. Die Rolle der Keuschheit bei der Entstehung des westlichen Klosterwesens, Münster 2005

Diesenberger, Maximilian, How Collections shape the Texts: Rewriting and Rearranging Passions in Carolingian Bavaria, in: Livrets, collections et textes. Études sur la tradition hagiographique latine, hrsg. von Martin Heinzelmann, Ostfildern 2006, 195-224

di Napoli, Giovanni, Communicantes e Nobis quoque. Un'ipotesi sulla loro origine e funzione, in: EO 12, 1995, 395-437

di Napoli, Giovanni, Hanc igitur: una formula per raccomandare specifiche oblate, in: EO 14, 1997, 185-231

Dinkler, Erich, s. v. „Friede“, in: RAC 8, Stuttgart 1972, 434-505

Dinkler, Erich, Schalom - Eirene - Pax. Jüdische Sepulkralinschriften und ihr Verhältnis zum frühen Christentum, in: RivAC 50, 1974, 121-144

Dodds, Eric R., Heiden und Christen in einem Zeitalter der Angst. Aspekte religiöser Erfahrung von Mark Aurel bis Konstantin, Frankfurt a. M. 1985 (Cambridge 1965)

Dölger, Franz J., Ichthys, Bd. 2: Der heilige Fisch in den antiken Religionen und im Christentum. Textband, Münster 1922

Dölger, Franz J., Die Heiligkeit des Altars und ihre Begründung im christlichen Altertum in: AuC 2, 1930, 161-183 
v. Döllinger, J. J. Ignaz, Die Papst-Fabeln des Mittelalters. Ein Beitrag zur Kirchengeschichte, München 1863

Domagalski, Bernhard, Römische Diakone im 4. Jahrhundert. Zum Verhältnis von Bischof, Diakon und Presbyter, in: Der Diakon. Wiederentdeckung und Erneuerung seines Dienstes, hrsg. von Josef G. Plöger/ Hermann J. Weber, Freiburg 1980, 44-56

Dresken-Weiland, Jutta, Fremde in der Bevölkerung des kaiserzeitlichen Rom, in: RQA 98, 2003, 18-34

Drijvers, Jan W., Helena Augusta. The Mother of Constantine the Great and the Legend of Her Finding of the True Cross, Leiden 1992

Dubois, Jacques, Les martyrologes du Moyen Âge latin, Turnhout 1978

Duchesne, Louis, Notes sur la topographie de Rome au moyen-âge III: SainteAnastasie, in: MEFR 7, 1887, 387-413

Duchesne, Louis, Vaticana (suite). Notes sur la topographie de Rome au moyen-âge XI, in: MEFR 22, 1902, 385-428

Duchesne, Louis, Libère et Fortunatien, in: MEFR 28, 1908, 31-78

Duchesne, Louis, Les légendes de l'Alta Semita, in: MEFR 36, 1916-17, 27-56

Duchesne, Louis, La memoria apostolorum de la via Appia, in: MPARA 1, 1, 1923, 1-22

Dufourcq, Albert, Étude sur les gesta martyrum romains, 5 Bde., Paris 1900$1910 / 1988$

Dufourcq, Albert, Le passionaire occidental au VIIe siècle, in: MEFR 26, 1906, 27-65

Dulière, Cécile, Lupa romana. Recherches d'iconographie et essai d'interprétation, 2 Bde., Brüssel 1979

Duncan-Jones, Richard, The Economy of the Roman Empire. Quantitative Studies, Cambridge 21982

Durliat, Jean, Les finances publiques de Dioclétien aux Carolingiens (284-889), Sigmaringen 1990

Duval, Yvette, Loca sanctorum Africae. Le culte des martyrs en Afrique du IVe au VIIe siècle, 2 Bde, Rom 1982

Duval, Yvette, Chrétiens d'Afrique à l'aube de la paix constantinienne. Les premiers échos de la grande persécution, Paris 2000

Duval, Yvette/Pietri, Luce, Évérgetisme et épigraphie dans l'occident chrétien (IVeVIe s.), in: Actes du Xe Congrès International d'épigraphie grecque et latine, Nimes, 4.-9. 10. 1992, hrsg. von Michel Christol/Olivier Masson, Paris 1997, 371-396

Dvornik, Francis, The Idea of Apostilicity in Byzantium and the Legend of the Apostle Andrew, Cambridge (Mass.) 1958 
Ebner, Adalbert, Die klösterlichen Gebets-Verbrüderungen bis zum Ausgange des karolingischen Zeitalters. Eine kirchengeschichtliche Studie, Regensburg u. a. 1890

Eck, Werner, Ehrungen für Personen hohen soziopolitischen Ranges im öffentlichen und privaten Bereich, in: Die römische Stadt im 2. Jahrhundert n. Chr. Der Funktionswandel des öffentlichen Raums, Kolloquium Xanten, 2. - 4. 5. 1990, hrsg. von Hans-Joachim Schalles/Henner v. Hesberg/Paul Zanker, Köln 1992, 359-376

Eck, Werner, Graffiti an Pilgerorten im spätrömischen Reich, in: Akten des XII. Internationalen Kongresses für Christliche Archäologie, Bonn 22.-28. 9. 1991, Bd. 1, Münster 1995, 206-222

Eck, Werner, Der Euergetismus im Funktionszusammenhang der kaiserzeitlichen Städte, in: Actes du Xe Congrès International d'épigraphie grecque et latine, Nimes, 4.-9. 10. 1992, hrsg. von Michel Christol/Olivier Masson, Paris 1997, 305-331

Eck, Werner, Lateinische Epigraphik, in: Einleitung in die lateinische Philologie, hrsg. von Fritz Graf, Stuttgart/Leipzig 1997, 92-111 (zit. Eck 1997 [a])

Eck, Werner/Caballos, Antonio/Fernández, Fernando, Das senatus consultum de Cn. Pisone patre, München 1996

Eggers, Stephan, Auf den Spuren der „verlorenen Zeit“. Maurice Halbwachs und die Spuren des kollektiven Gedächtnisses, in: Maurice Halbwachs, Stätten der Verkündigung im Heiligen Land. Eine Studie zum kollektiven Gedächtnis, hrsg. u. übers. von Stephan Eggers, Konstanz 2003, 219-268

Eich, Peter, Zur Metamorphose des politischen Systems in der römischen Kaiserzeit. Die Entstehung einer „personalen Bürokratie“ im langen dritten Jahrhundert, Berlin 2005

Eigler, Ulrich, Lectiones vetustatis. Römische Literatur und Geschichte in der lateinischen Literatur der Spätantike, München 2003

Eizenhöfer, Leo, Te igitur und communicantes im römischen Meßkanon, in: SE 8, 1956, 14-75

Ekroth, Gunnel, Pausanias and the Sacrificial Rituals of Greek Hero-Cults, in: Ancient Greek Hero Cult, hrsg. von Robin Hägg, Stockholm 1999, 145-158

Ekroth, Gunnel, The Sacrificial Rituals of Greek Hero-Cults in the Archaic to the Early Hellenistic Periods, Lüttich 2002

Ellis, Simon P., The End of the Roman House, in: AJA 92, 1988, 565-576

Ellis, Simon P., Roman Housing, London 2000

Elm, Susanna, ,Virgins of God'. The Making of Asceticism in Late Antiquity, Oxford 1994

Engberding, Hieronymus, Das anaphorische Fürbittgebet der griechischen Markusliturgie, in: OCP 30, 1964, 398-446 
Ensoli, Serena, I colossi di bronzo a Roma in età tardoantica: dal Colosso di Nerone al Colosso di Costantino. A proposito dei tre frammenti bonzei dei Musei Capitolini, in: Aurea Roma. Dalla città pagana alla città cristiana, hrsg. von Serena Ensoli/Eugenio La Rocca, Rom 2000, 66-90

Episcopo, Silvana, L'ecclesia baptismalis nel suburbio di Roma, in: Atti del VI Congresso nazionale di Archeologia Cristiana, Ancona 1985-1986, 297-308

Ewald, Paul, Die Briefe des Paulus an die Epheser, Kolosser und Philemon, Leipzig 1905

Ewig, Eugen, Die Kathedralpatrozinien im römischen und im fränkischen Gallien, in: HJ 79, 1960, 1-60

Ewig, Eugen, Der Petrus- und Apostelkult im spätrömischen und fränkischen Gallien, in: ZKG 71, 1960, 215-251 (zit. Ewig 1960 [a])

Faivre, Alexandre, Naissance d'une hiérarchie. Les premières étapes du cursus clérical, Paris 1977

Fasola, Umberto M., La memoria di S. Pietro nella regione Salario-Nomentana, in: Saecularia Petri et Pauli, Vatikanstadt 1969, 107-128

Fasola, Umberto M., La „Regio IV“ del cimitero di S. Agnese sotto l'atrio della basilica costantiniana, in: RivAC 50, 1974, 174-205

Fasola, Umberto M., Scoperta di un probabile santuario di martiri in una regione postcostantiniana della catacomba ad duas lauros, in: RPARA 55-56, 1982-1984, 341-359

Fasola, Umberto M., Santuari sotteranei di Damaso nelle catacombe romane - I contributi di una recente ricercha, in: Saecularia Damasiana. Atti del convegno internazionale per il XVI centenario della morte di papa Damaso I (11. 12. 384 - 10./12. 12. 1984), Vatikanstadt 1986, 173-201

Fasola, Umberto M./Fiocchi Nicolai, Vincenzo, Le necropoli durante la formazione della città cristiana, in: Actes du XIe congrès international d'archéologie chrétienne, Bd. 2, Rom 1989, 1153-1205

Fee, Gordon D., Paul's Letter to the Philippians, Michigan 1995

Felle, Antonio/del Moro, Maria P./Nuzzo, Donatella, Elementi di „corredo-arredo“ delle tombe del cimitero di S. Ippolito sulla via Tiburtina, in: RivAC 70, 1994, 89158

Fellermayr, Josef, Tradition und Sukzession im Lichte des römisch-antiken Erbdenkens. Untersuchungen zu den lateinischen Vätern bis zu Leo dem Großen, München 1979

Fenwick, John R. K., The Anaphoras of St Basil and St James. An Investigation in their Common Origin, Rom 1992

Ferrari, Guy, Early Roman Monasteries. Notes for the History of the Monasteries and Convents at Rome from the V through the X Century, Vatikanstadt 1957 
Ferrua, Antonio, I più antichi esempi di basilica per „aedes sacra“, in: AGI 25, 1931 $1933,142-146$

Ferrua, Antonio, Di una comunità montanista sull'Aurelia alle fine del IV secolo, in: CivCatt 87, 2, 1936, 216-227

Ferrua, Antonio, Una nuova catacomba sulla via Latina, in: CivCatt 89, 2, 1938, 151 163

Ferrua, Antonio, Le tre Rome Sotterranee, in: CivCatt 89,3, 1938, 399-412 (zit. Ferrua 1938 [a])

Ferrua, Antonio, S. Maria Maggiore e la basilica Sicinini, in: CivCatt 89, 3, 1938, 53-61 (zit. Ferrua 1938 [b])

Ferrua, Antonio, Il refrigerio dentro la tomba, in: CivCatt 92, 2, 1941, 373-378 u. 457463

Ferrua, Antonio, I monumenti eretici di Roma, in: CivCatt 95, 2, 1944, 388-392

Ferrua, Antonio, Novatiano beatissimo martyri, in: CivCatt 95, 4, 1944, 232-239 (zit. Ferrua 1944 [a])

Ferrua, Antonio, Questioni di epigrafia eretica romana, in: RivAC 21 1944/1945, 165221

Ferrua, Antonio, Intorno ad una dedica damasiana, in: RivAC 29, 1953, 231-235

Ferrua, Antonio, Catacomba ai Giordani, in: BCAR 75, 1953-1955, 167-171

Ferrua, Antonio, L'espressione in Lucinis, in: RivAC 30, 1954, 235

Ferrua, Antonio, Lavori a S. Sebastiano, in: RivAC 37, 1961, 203-236

Ferrua, Antonio, Rileggendo i graffiti di S. Sebastiano, in: CivCatt 116, 3, 1965, 428437 u. 116, 4, 1965, 134-141

Ferrua, Antonio, Memorie dei SS. Pietro e Paolo nell'epigrafia, in: Saecularia Petri et Pauli, Vatikanstadt 1969, 129-148

Ferrua, Antonio, L'epigrafia cristiana prima di Costantino, in: Atti del IX Congresso Internazionale di Archeologia Cristiana, Bd. 1, Vatikanstadt 1978, Bd. 1, 583-613

Ferrua, Antonio, Sigilli su calce nelle catacombe, Vatikanstadt 1986

Ferrua, Antonio, La polemica antiariana nei monumenti paleocristiani, Vatikanstadt 1991

Festy, Michel, Le début et la fin des Annales de Nicomaque Flavien, in: Historia 46, 1997, 465-478

Février, Paul-Albert, Permanence et héritages de l'antiquité dans la topographie des villes de l'occident durant de haut moyen âge, in: SSAM 21: Topografia urbana e vita cittadina nell'Alto Medioevo in occidente, Spoleto 1974, Bd. 1, 41-138 
Février, Paul-Albert, Natale Petri de cathedra, in: CRAI 1977, 514-531

Février, Paul-Albert, Le culte des morts dans les communautés chrétiennes durant le IIIe siècle, in: Atti del IX Congresso Internazionale di Archeologia Cristiana, Bd. 1, Vatikanstadt 1978, Bd. 1, 211-274

Février, Paul-Albert, La tombe chrétienne et l'au-delà, in: Le temps chrétien de la fin de l'antiquité au moyen age (IIIe - XIIIe siècles), Colloque CNRS, 9.-12. 3. 1981, Paris 1984, 163-183

Février, Paul-Albert, Baptistères, martyrs et reliques, in: RivAC 62, 1986, 109-138

Février, Paul-Albert, Arles, in: Topographie chrétienne des cités de la Gaule des origines au milieu du VIIIe siècle, hrsg. von Nancy Gauthier/Jean-Charles Picard, Bd. 3: Provinces ecclésiastiques de Vienne et d'Arles (Viennensis et Alpes Graiae et Poeninae), Paris 1986, 73-84 (zit. Février 1986 [a])

Février, Paul-Albert, Kult und Geselligkeit: Überlegungen zum Totenmahl, in: Christentum und antike Gesellschaft, hrsg. von Jochen Martin/Babara Quint, Darmstadt 1990, 358-390 (À propos du repas funéraire: culte et sociabilité, in: CArch 26, 1977, 29-45)

Février, Paul-Albert, Martyre et sainteté, in: Les fonctions des saints dans le monde occidental (IIIe - XIIIe siècle) (Actes du colloque Rome, 27-29. 10 1988), Rom 1991, 51-80

Février, Paul-Albert, Un plaidoyer pour Damase: les inscriptions des nécropoles romaines, in: Institutions, société et vie politique dans l'empire romain au IVe siècle ap. J.-C., hrsg. von Michel Christol u. a., Rom 1992, 497-506

Février, Paul-Albert, Roma. Il prestigio della città pagana, in: Storia di Roma, Bd. 3, 2: L'età tardoanticha. I luoghi e le culture, hrsg. von Andrea Carandini u. a., Turin 1993, 41-51

Finé, Heinz, Die Terminologie der Jenseitsvorstellungen bei Tertullian. Ein semasiologischer Beitrag zur Dogmengeschichte des Zwischenzustandes, Bonn 1958

Finn, Richard, Almsgiving in the Later Roman Empire. Christian Promotion and Practice (313-450), Oxford 2006

Fiocchi Nicolai, Vincenzo, Itinera ad sanctos. Testimonianze monumentali del passaggio dei pellegrini nei santuari del suburbio romano, in: Akten des 12. Internationalen Kongresses für Christliche Archäologie, Bonn 22.-28. 9. 1991, Bd. 2, Münster 1995, 763-775

Fiocchi Nicolai, Vincenzo, La nuova basilica circiforme della via Ardeatina, in: RPARA 68, 1995-1996, 69-233

Fiocchi Nicolai, Vincenzo, Strutture funerarie ed edifici di culto paleocristiani di Roma dal III al VI secolo, in: Le iscrizioni dei cristiani in Vaticano: materiali e 
contributi scientifici per una mostra epigrafica (Inscriptiones Sanctae Sedis, Bd. 2), hrsg. von Ivan DiStefano Manzella, Rom 1997, 121-141

Fiocchi Nicolai, Vincenzo, Ursprung und Entwicklung der römischen Katakomben, in: Vincenzo Fiocchi Nicolai/Fabio Bisconti/Danilo Mazzoleni, Roms christliche Katakomben. Geschichte - Bilderwelt - Inschriften, Regensburg 1998, 9-69

Fiocchi Nicolai, Vincenzo, Alle origini della parrocchia rurale nel Lazio (IV-VI sec.), in: Alle origini della parrocchia rurale (IV-VIII sec.), hrsg. von Philippe Pergola, Vatikanstadt 1999, 445-485

Fiocchi Nicolai, Vincenzo, Basilica Marci, Coemeterium Marci, Basilica Coemeterii Balbinae, in: Ecclesiae urbis. Atti del Congresso internazionale di studi sulle chiese di Roma (IV-X secolo), hrsg. von Federico Guidobaldi/Alessandra Guiglia Guidobaldi, Vatikanstadt 2002, Bd. 2, 1175-1201

Fiocchi Nicolai, Vincenzo/v. Hesberg, Henner/Ristow, Sebastian, s. v. „Katakombe (Hypogaeum)“, in: RAC 20, Stuttgart 2003, 342-422

Fiore, F. Paolo, L'impianto architettonico antico, in: Il „tempio di Romolo“ al foro romano, Rom 1981, 63-90

Fishwick, Duncan, The Imperial Cult in the Latin West. Studies in the Ruler Cult of the Western Provinces of the Roman Empire, Leiden u. a. 1987-2004

Flaig, Egon, Den Kaiser herausfordern. Die Usurpation im Römischen Reich, Frankfurt a. M. 1992

Flaig, Egon, Die pompa funebris. Adlige Konkurrenz und annalistische Erinnerung, in: Memoria als Kultur, hrsg. von Otto G. Oexle, Göttingen 1995, 115-148

Flaig, Egon, Entscheidung und Konsens: $\mathrm{Zu}$ den Feldern der politischen Kommunikation zwischen Aristokratie und Plebs, in: Demokratie in Rom? Die Rolle des Volkes in der Politik der römischen Republik, hrsg. von Martin Jehne, Stuttgart 1995, 77-127 (zit. Flaig 1995 [a])

Flaig, Egon, Ritualisierte Politik. Zeichen, Gesten und Herrschaft im Alten Rom, Göttingen 2003

Flower, Harriet I., Ancestor Masks and Aristocratic Power in Roman Culture, Oxford 1996

Follieri, Enrica, Antiche chiese romane nella Passio greca di Sisto, Lorenzo ed Ippolito, in: RSBN 17/19, 1980/82, 43-71

Fontaine, Jacques, Le culte des saints et ses implications sociologiques. Réflexions sur un récent essai de Peter Brown, in: AB 100, 1982, 19-41

Fontaine, Jacques, Damase poète théodosien: l'imaginaire poétique des Epigrammata, in: Saecularia damasiana. Atti del convegno internazionale per il XVI centenario della morte di papa Damaso I (11. 12. 384 - 10./12. 12. 1984), Vatikanstadt 1986, 113-145 
Förster, Hans, Die Feier der Geburt Christi in der Alten Kirche. Beiträge zur Erforschung der Anfänge des Epiphanie- und des Weihnachtsfests, Tübingen 2000

Foss, Pedar W. Watchful lares: Roman Household Organization and the Rituals of Cooking and Eating, in: Domestic Space in the Roman World: Pompeii and beyond, hrsg. von Ray Laurence/Andrew Wallace-Hadrill, Portsmouth 1997, 196218

Fowden, Garth, Constantine's Porphyry Column: The Earliest Literary Allusion, in: JRS 81, 1991, 119-131

Fowden, Garth, The Last Days of Constantine. Oppositional Versions and their Influences, in: JRS 84, 1994, 146-170

Franchi de' Cavalieri, Pio, S. Agnese nella tradizione e nella leggenda, Rom 1899

Franchi de' Cavalieri, Pio, S. Martina, in: RQA 17, 1903, 222-236

Franchi de' Cavalieri, Pio, Del testo della passio ss. Iohannis et Pauli in: ders., Note agiografiche 5 (Studi e Testi 27), Rom 1915, 41-62

Franchi de' Cavalieri, Pio, S. Susanna e il titulus Gai, in: ders., Note agiografiche 7 (Studi e testi 49), 1928, 185-202

Franchi de' Cavalieri, Pio, Dove furono sepolti i ss. Cipriano, Giustina e Teoctisto?, in: ders., Note agiografiche 8 (Studi e testi 65), Rom 1935, 341-354

Franchi de' Cavalieri, Pio, Della custodia Mamertini e della passio SS. Processi e Martiniani, in: ders., Note agiografiche 9 (Studi e testi 175), Rom 1953, 1-52

François, Etienne, Pierre Nora und die „Lieux de mémoire“, in: Erinnerungsorte Frankreichs, hrsg. von Pierre Nora, München 2005, 7-14

François, Etienne/Schulze, Hagen, Einleitung, in: Deutsche Erinnerungsorte, Bd. 1, hrsg. von Etienne François/Hagen Schulze, München 2001, 9-24

Frank, Hieronymus, Zwei Fälschungen auf den Namen Gregors d. Gr. und Bonifatius IV., in: SMGB 55, 1937, 19-47

Frank, Hieronymus, Beobachtungen zur Geschichte des Meßkanons, in: ALW 1, 1950, 107-119

Frank, Karl S., Geschichte des christlichen Mönchtums, Darmstadt 51993

Fraschetti, Augusto, Morte dei „principi“ ed „eroi“ della famiglia di Augusto, in: AION(archeol) 6, 1984, 151-189

Fraschetti, Augusto, Spazi del sacro e spazi della politica, in: Storia di Roma, Bd. 3, 1: L'età tardoantica. Crisi e trasformazioni, hrsg. von Andrea Carandini u. a., Turin 1993, 675-696

Fraschetti, Augusto, Costantino e Roma, in: ders., La conversione da Roma pagana a Roma cristiana, Rom/Bari 1999, 3-127 (überarbeitete und erweiterte Fassung von: Costantino e l'abbandono del Campidoglio, in: Società romana e impero 
tardoantico, Bd. 2: Roma. Politica, economia, paesaggio urbano, hrsg. von Andrea Giardina, Rom/Bari 1986, 59-98 u. 412-438)

Fraschetti, Augusto, Veniunt modo reges Romam, in: The Transformations of urbs Roma in Late Antiquity, hrsg. von William V. Harris, Rom 1999, 235-248 (zit. Fraschetti 1999 [a])

Fraschetti, Augusto, L'eorizzazione di Germanico, in: La commemorazione di Germanico nella documentazione epigrafica. Tabula Hebana e Tabula Siarensis, hrsg. von Augusto Fraschetti, Rom 2000, 141-162

Frazer, Alfred K., Four Late Antique Rotundas: Aspects of Fourth Century Architectural Style in Rome, Diss. New York 1964

Frazer, Alfred K., The Iconography of the Emperor Maxentius' Buildings in via Appia, in: ArtB 48, 1966, 385-392

Frend, William H. C., The Donatist Church. A Movement of Protest in Roman North Africa, Oxford 1952

Frend, William H. C., Martyrdom and Persecution in the Early Church. A Study of a Conflict from the Maccabees to Donatus, Oxford 1965 (zit. nach dem leicht veränderten ND Grand Rapids 1981)

Fried, Johannes, Der Schleier der Erinnerung. Grundzüge einer historischen Memorik, München 2004

Frischer, Bernard, Monumenta et arae honoris virtutisque causa: Evidence of Memorials for Roman Civic Heroes, in: BCAR 88, 1982-1983, 51-86

Furtwängler, Adolf, s. v. „Dioskuren“, in: Ausführliches Lexikon der griechischen und römischen Mythologie, hrsg. von Wilhelm H. Roscher, Bd. I, 1, Leipzig 1884-1886, 1154-1177

Gagé, Jean, Le „Templum Urbis“ et les origines de l'idée de „Renovatio“, in: Mélanges Franz Cumont I (AIPh 4, 1), Brüssel 1936, 151-187

Gagov, Giuseppe, Il culto delle reliquie nell'antichità : riflesso nei due termini patrocinia e pignora, in: MF 58, 1958, 484-512

de Gaiffier, Baudouin, La lecture des actes des martyrs dans la prière liturgique en occident à propos du passionaire hispanique, in: AB 72, 1954, 134-166

de Gaiffier, Baudouin, Un prologue hagiographique hostile au décret de Gélase?, in: AB 82, 1964, 341-353

de Gaiffier, Baudouin, Saints et légendiers de l'Ombrie, in: Atti del II Convegno di Studi Umbri, Perugia 1965, 235-256

de Gaiffier, Baudouin, La lecture des passions des martyrs à Rome avant le IXe siècle, in: $\mathrm{AB} 87,1969,63-78$ 
Gamber, Klaus, Missa romensis. Beiträge zur frühen römischen Liturgie und zu den Anfängen des Missale Romanum, Regensburg 1970

Geertman, Herman, Ricerche sopra la prima fase di S. Sisto Vecchio in Roma, in: RPARA 41, 1968-1969, 219-228

Geertman, Herman, More veterum. Il Liber Pontificalis e gli edifici ecclesiastici di Roma nella tarda antichità e nell'alto medioevo, Groningen 1975

Geertman, Herman, Forze centrifughe e centripete nella Roma cristiana: il Laterano, la basilica Iulia e la basilica Liberiana, in: RPARA 59, 1986-1987, 63-91

Geertman, Herman, L’illuminazione della basilica paleocristiana secondo il Liber Pontificalis, in: RivAC 64, 1988, 135-160

Geertman, Herman, Cripta anulare ante litteram. Forma, contesto e significato del monumento sepolcrale di San Lorenzo a Roma, in: Martyrium in Multidisciplinary Perspective. Memorial Louis Reekmans, hrsg. von Mathijs Lamberigts/Peter van Deun, Löwen 1995, 125-155

Geertman, Herman, La basilica maior di S. Lorenzo f.l.m., in: Ecclesiae urbis. Atti del Congresso internazionale di studi sulle chiese di Roma (IV-X secolo), hrsg. von Federico Guidobaldi/Alessandra Guiglia Guidobaldi, Vatikanstadt 2002, Bd. 2, 1225-1247

Geertman, Herman, Documenti, redattori e la formazione del testo del Liber Pontificalis, in: Atti del colloquio internazionale „Il Liber Pontificalis e la storia materiale" (MNHIR 60/61 [2001-2002]), hrsg. von Herman Geertman, Rom 2003, 267-284

Geertman, Herman, Le biografie del Liber Pontificalis dall 311 al 535. Testo e commento, in: Atti del colloquio internazionale „Il Liber Pontificalis e la storia materiale" (MNHIR 60/61 [2001-2002]), hrsg. von Herman Geertman, Rom 2003, 285-355 (zit. Geertman 2003 [a])

Geertman, Herman, Il fastigium lateranense e l'arredo presbiteriale. Una lunga storia, in: in: Atti del colloquio internazionale „Il Liber Pontificalis e la storia materiale" (MNHIR 60/61 [2001-2002]), hrsg. von Herman Geertman, Rom 2003, 29-43 (zit. Geertman 2003 [b])

Gehrke, Hans-Joachim, Identität und Alterität, in: Oldenbourg Geschichte Lehrbuch, Antike, hrsg. von Eckhard Wirbelauer, München 2004, 362-375

Geppert, Stefan, Castor und Pollux. Untersuchung zu den Darstellungen der Dioskuren in der römischen Kaiserzeit, Münster 1996

Geraci, Giovanni, Ricerche sul proskynema, in: Aegyptus 51, 1971, 3-211

Giordani, Roberto, Novatiano beatissimo marturi Gaudentius diaconus fecit: contributo all' identificazione del martire Novaziano della catacomba anonima sulla via Tiburtina, in: RivAC 68, 1992, 233-258 
Girardet, Klaus M., Kaisergericht und Bischofsgericht. Studien zu den Anfängen des Donatistenstreites (313-315) und zum Prozeß des Athanasius von Alexandrien (328-346), Bonn 1975

Girardet, Klaus M., Gericht über den Bischof von Rom. Ein Problem der kirchlichen und der staatlichen Justiz in der Spätantike (4. - 6. Jahrhundert), in: HZ 259, 1994, $1-38$

Girardet, Klaus M., Die Konstantinische Wende und ihre Bedeutung für das Reich. Althistorische Überlegungen zu den geistigen Grundlagen der Religionspolitik Konstantins d. Gr., in: Die Konstantinische Wende, hrsg. von Ekkehard Mühlenberg, Gütersloh 1998, 9-122

Giuliani, Cairoli F./Verduchi, Patrizia, L'area centrale del foro romano, Florenz 1987

Giuliani, Luca, Des Siegers Ansprache an das Volk: Zur politischen Brisanz der Frieserzählung am Constantinsbogen, in: Rede und Redner. Bewertung und Darstellung in den antiken Kulturen, hrsg. von Christoff Neumeister/Wulf Raeck, Möhnesee 2000, 269-287

Godding, Robert, Prêtres en Gaule mérovingienne, Brüssel 2001

Gordini, Gian D., Origine e sviluppo dem monachesimo a Roma, in: Gregorianum $37,1956,220-260$

Gotter, Ulrich, ‘Akkulturation' als Methodenproblem der historischen Wissenschaften, in: Posthumanistische Klassische Archäologie, Kolloquium Berlin 19.-21. 2. 1999, München 2001, 255-286

Grabar, André, Martyrium. Recherches sur le culte des reliques et l'art chrétien antique, 2 Bde., Paris 1943-1946

Gradel, Ittai, Emperor Worship and Roman Religion, Oxford 2002

des Graviers, Jean, La dédicace des lieux de culte aux Ve et VIe siècles, in: ACan 7, $1962,107-125$

Green, Roger P. H., Proba's Cento: Its Date, Purpose, and Reception, in: CQ 45, $1995,551-563$

Griffe, Élie, En relisant l'inscription damasienne ad catacumbas, in: BLE 71, 1970, 81 91

Grisar, Hartmann, S. Anastasia di Roma e l'Anastasis di Gerusalemme e di Costantinopoli, in: CivCatt 47, 3, 1896, 727-741

Große-Kracht, Klaus, Gedächtnis und Geschichte. Maurice Halbwachs - Pierre Nora, in: GWU 47, 1996, 21-31

Grossi, Vittorino, Il Decretum Gelasianum. Nota in margine all'autorità della chiesa di Roma alla fine del sec. V, in: Augustinianum 41, 2001, 231-255 
Grossi-Gondi, Felice, Il Refrigerium celebrato in onore dei SS. Apostoli Pietro e Paolo nel secolo IV ad Catacumbas, in: RQA 29, 1915, 221-268

Grünewald, Thomas, Constantinus Maximus Augustus. Herrschaftspropaganda in der zeitgenössischen Überlieferung, Stuttgart 1990

Gryson, Roger, Le ministère des femmes dans l’Église ancienne, Gembloux 1972

Guarducci, Margherita, I graffiti sotto la confessione di S. Pietro in Vaticano, 3 Bde., Vatikanstadt 1958

Guarducci, Margherita, Valentiniani a Roma: ricerche epigrafiche ed archeologiche, in: MDAI(R) 80, 1973, 169-189

Guarducci, Margherita, La statua di „Sant' Ippolito“ in Vaticano, in: RPARA 47, 1974-1975, 163-190

Guarducci, Margherita, Ancora sui Valentiniani a Roma, in: MDAI(R) 81, 1974, 341343

Guarducci, Margherita, Epigrafia Greca, Bd. 3, Rom 1974 (zitiert Guarducci 1974 [a])

Guarducci, Margherita, La statua di „Sant’ Ippolito“, in: Ricerche su Ippolito, Rom 1977, 17-30

Guarducci, Margherita, Il culto degli apostoli Pietro e Paolo sulla via Appia: riflessioni vecchie e nuove, in: MEFRA 98, 1986, 811-842

Guarducci, Margherita, La „statua di Sant’ Ippolito“ e la sua provenienza, in: Nuove ricerche su Ippolito, Rom 1989, 61-74

Guidobaldi, Federico, L'edilizia abitativa unifamiliare nella Roma tardoantica, in: Società romana e impero tardoantico, Bd. 2: Roma. Politica, economia, paesaggio urbano, hrsg. von Andrea Giardina, Rom/Bari 1986, 165-237 u. 446-460

Guidobaldi, Federico, L'inserimento delle chiese titolari nel tessuto urbano preesistente: osservazioni e implicazioni, in: Quaeritur inventus colitur. Miscellanea in onore di Umberto Fasola, Bd. 1, Vatikanstadt 1989, 381-396

Guidobaldi, Federico, San Clemente. Gli edifici romani, la basilica paleocristiana e le fasi altomedievali, 2 Bde., Rom 1992

Guidobaldi, Federico, Roma. Il tessuto abitativo, le domus e i tituli, in: Storia di Roma, Bd. 3, 2: L'età tardoantica. I luoghi e le culture, hrsg. von Andrea Carandini u. a., Rom 1993, 69-83

Guidobaldi, Federico, s. v. „domus: Iunius Bassus“, in: LTUR II, Rom 1995, $69 \mathrm{f}$.

Guidobaldi, Federico, s. v. „Sessorium“, in: LTUR IV, Rom 1999, 304-308

Guidobaldi, Federico, Le domus tardoantiche di Roma come „sensori“ delle trasformazioni culturali e sociali, in: The Transformations of urbs Roma in Late Antiquity, hrsg. von William V. Harris, Rom 1999, 53-68 (zit Guidobaldi 1999 [a]) 
Guidobaldi, Federico, Strutture liturgiche negli edifici cristiani di Roma dal IV al VII secolo, in: Materiali e tecniche dell'edilizia paleocristiana a Roma, hrsg. von Margherita Cecchelli, Rom 2001, 171-190

Guidobaldi, Federico, Osservazioni sugli edifici romani in cui si insedio l'ecclesia Pudentiana, in: Ecclesiae urbis. Atti del Congresso internazionale di studi sulle chiese di Roma (IV-X secolo), hrsg. von Federico Guidobaldi/Alessandra Guiglia Guidobaldi, Vatikanstadt 2002, Bd. 2, 1033-1071

Guidobaldi, Federico, La fondazione delle basiliche titolari di Roma nel IV e V secolo. Assenze e presenze nel Liber Pontificalis, in: Atti del colloquio internazionale „Il Liber Pontificalis e la storia materiale" (MNHIR 60/61 [2001-2002]), hrsg. von Herman Geertman, Rom 2003, 5-12

Gulowsen, Kirsti, The Cult of the Fourty Martyrs on the Forum Romanum, in: ActaHyp 8, 2001, 235-248

Gülzow, Henneke, Christentum und Sklaverei in den ersten drei Jahrhunderten, Bonn 1969

Günther, Otto, Avellana-Studien (SAWW.PH 134, Abh. 5), Wien 1896

Guyon, Jean, Les Quatre Couronnés et l'histoire de leur culte des origines au milieu du IXe siècle, in: MEFRA 87, 1, 1975, 505-561

Guyon, Jean, Culte des martyrs et culte des morts dans la société chrétienne du IVe au VIIe siècle: un cas de continuité cultuelle? L'exemple de la catacombe romaine ad duas lauros, in: Centro ricerche e documentazione sull'antichità classica, Atti 9, 197778, 201-228

Guyon, Jean, Le cimitière aux deux lauriers. Recherches sur les catacombes romaines, Rom 1987

Guyon, Jean, Roma. Emerge la città cristiana, in: Storia di Roma, Bd. 3, 2: L'età tardoantica. I luoghi e le culture, hrsg. von Andrea Carandini u. a., Turin 1993, 5368

Guyon, Jean, Peut-on vraiment dater une catacombe? Retour sur le cimitière „Aux deux lauriers", ou catacombe des saints Marcellin-et-Pierre sur la via Labicana à Rome, in: Boreas 17, 1994, 89-103

Guyon, Jean, Damase et l'illustration des martyrs: Les accents de la dévotion et l'enjeu d'une pastorale, in: Martyrium in Multidisciplinary Perspective. Memorial Louis Reekmans, hrsg. von Mathijs Lamberigts/Peter van Deun, Löwen 1995, 157-177

Guyon, Jean, La marque de la christianisation dans la topographie urbaine de Rome, in: La fin de la cité antique et le début de la cité médiévale: de la fin du IIIe siècle à l'avènement de Charlemagne, hrsg. von Claude Lepelley, Bari 1996, 213-237

Guyon, Jean, Die Kirche Roms vom Anfang des 4. Jahrhunderts bis zu Sixtus III. (312-432), in: Die Geschichte des Christentums. Religion - Politik - Kultur, Bd. 2: 
Das Entstehen der einen Christenheit (250-430), hrsg. von Charles und Luce Pietri, Freiburg 1996, 877-917 (zit. Guyon 1996 [a])

Hack, Achim, Zur römischen Doppelapostolizität. Überlegungen ausgehend von einem Epigramm Papst Damasus' I. (366-384), in: Hagiographica 4, 1997, 9-33

Halbwachs, Maurice, Das kollektive Gedächtnis, Stuttgart 1967 (La mémoire collective, Paris 1950)

Hales, Shelley, The Roman House and Social Identity, Cambridge 2003

Hamman, Adalbert G., Vie liturgique et vie sociale. Repas des pauvres, diaconie et diaconat, agape et repas de charité, offrande dans l'antiquité chrétienne, Paris 1968

Haendler, Gert, Die Rolle des Papsttums in der Kirchengeschichte bis 1200. Ein Überblick und achtzehn Untersuchungen, Göttingen 1993

v. Harnack, Adolf, Mission und Ausbreitung des Christentums in den ersten drei Jahrhunderten, 2 Bde., Leipzig 41924

Haug, Annette, Die Stadt als Lebensraum. Eine kulturhistorische Analyse zum spätantiken Stadtleben in Norditalien, Rahden 2003

Häusle, Helmut, Das Denkmal als Garant des Nachruhms. Eine Studie zu einem Motiv in lateinischen Inschriften, München 1980

Häußling, Angelus A., Mönchskonvent und Eucharistiefeier. Eine Studie über die Messe in der abendländischen Klosterliturgie des frühen Mittelalters und zur Geschichte der Meßhäufigkeit, Münster 1973

Heinzelmann, Michael, Die Nekropolen von Ostia. Untersuchungen zu den Gräberstraßen vor der Porta Romana und an der Via Laurentina, München 2000

Heinzelmann, Michael, Grabarchitektur, Bestattungsbrauch und Sozialstruktur - zur Rolle der familia, in: Römischer Bestattungsbrauch und Beigabesitten in Rom, Norditalien und den Westprovinzen von der späten Republik bis in die Kaiserzeit, hrsg. von Michael Heinzelmann u. a., Wiesbaden 2001, 179-191

Heisenberg, August, Grabeskirche und Apostelkirche. Zwei Basiliken Konstantins. Untersuchungen zur Kunst und Literatur, Teil 2: Die Apostelkirche in Konstantinopel, Leipzig 1908

Heres, Theodora L., Paries. A Proposal for a Dating System of Late-Antique Masonry Structures in Roma and Ostia, Amsterdam 1982

Hermann, Alfred, s. v. „Capitolium“, in: RAC, Bd. 2, Stuttgart 1954, 847-861

Hermes, Raimund, Die stadtrömischen Diakonien, in: RQA 91, 1996, 1-120

Herrmann, Peter/Waszink, Jan H./Colpe, Carsten/Kötting, Bernhard, s. v. „Genossenschaft“, in: RAC 10, Stuttgart 1978, 83-155

Herzog, Reinhart, Einführung in die lateinische Literatur der Spätantike, in: Handbuch der lateinischen Literatur der Antike, Bd. 5: Restauration und 
Erneuerung. Die lateinische Literatur von 284 bis 375 n. Chr., hrsg. von Reinhart Herzog, München 1989, 1-44

v. Hesberg, Henner, Planung und Ausgestaltung der Nekropolen Roms im 2. Jh. n. Chr., in: Römische Gräberstraßen. Selbstdarstellung - Status - Standard. Kolloquium München, 28. - 30. 10. 1985, hrsg. von Henner v. Hesberg/Paul Zanker, München 1987, 43-60

v. Hesberg, Henner, Römische Grabbauten, Darmstadt 1992

v. Hesberg, Henner/Panciera, Silvio, Das Mausoleum des Augustus. Der Bau und seine Inschriften, München 1994

Hess, Hamilton, The Canons of the Council of Sardica A. D. 343. A Landmark in the Early Development of Canon Law, Oxford 1958

Hillner, Julia, Le chiese paleocristiane di Roma e l'occupazione degli spazi pubblici, in: Ecclesiae urbis. Atti del Congresso internazionale di studi sulle chiese di Roma (IV-X secolo), hrsg. von Federico Guidobaldi/Alessandra Guiglia Guidobaldi, Vatikanstadt 2002, Bd. 1, 321-329

Hillner, Julia, Domus, Family, and Inheritance: The Senatorial Family House in Late Antiquity, in: JRS 93, 2003, 129-145

Hillner, Julia, Jedes Haus ist eine Stadt. Privatimmobilien im spätantiken Rom, Bonn 2004

Hillner, Julia, Clerics, Property and Patronage: The Case of the Roman Titular Churches, in: AntTard 14, 2006, 59-68

Hölkeskamp, Karl-Joachim, Exempla und mos maiorum. Überlegungen zum kollektiven Gedächtnis der römischen Nobilität, in: Vergangenheit und Lebenswelt. Soziale Kommunikation, Traditionsbildung und historisches Bewußtsein, hrsg. von HansJoachim Gehrke/Astrid Möller, Tübingen 1996, 301-333

Hölkeskamp, Karl-Joachim, Capitol, Comitium und Forum. Öffentliche Räume, sakrale Topographie und Erinnerungslandschaften der römischen Republik, in: Studien zu antiken Identitäten, hrsg. von Stefan Faller, Würzburg 2001, 97-132

Holloway, R. Ross, Constantine and Rome, New Haven/London 2004

Hölscher, Lucian, s. v. „Öffentlichkeit“, in: Geschichtliche Grundbegriffe, hrsg. von Otto Brunner/Werner Conze/Reinhart Koselleck, Bd. 4, Stuttgart 1978, 413-467

Hölscher, Lucian, Öffentlichkeit und Geheimnis. Eine begriffsgeschichtliche Untersuchung zur Entstehung der Öffentlichkeit in der frühen Neuzeit, Stuttgart 1979

Hölscher, Tonio, Die Alten vor Augen. Politische Denkmäler und öfentliches Gedächtnis im republikanischen Rom, in: Institutionalität und Symbolisierung. Verstetigung kultureller Ordnungsmuster in Vergangenheit und Gegenwart, hrsg. von Gert Melville, Köln u. a. 2001, 183-211 
Hopkins, Keith, Christian Number and Its Implications, in: JECS 6, 1998, 185-226

Horster, Marietta, Ehrungen spätantiker Statthalter, in: AntTard 6, 1998, 37-59

Huber-Rebenich, Gerlinde, Hagiographic Fiction as Entertainment, in: Latin Fiction. The Latin Novel in Context, hrsg. von Heinz Hofmann, London 1999, 187-212

Huelsen, Christian, Le chiese di Roma nel medio evo. Cataloghi ed appunti, Florenz 1927

Humphries, Mark, Communities of the Blessed. Social Environment and Religious Change in Northern Italy, AD 200-400, Oxford 1999

Hunt, Edward D., St. Silvia of Aquitaine. The Role of a Theodosian Pilgrim in the Society of East and West, in: JThS, n. s. 23, 1972, 351-373

Hunt, Edward D., Imperial Building at Rome. The Role of Constantine, in: ,Bread and Circuses'. Euergetism and Municipal Patronage in Roman Italy, hrsg. von Kathryn Lomas/Tim Cornell, London/New York 2003, 105-124

Huskinson, John M., Concordia apostolorum: Christian Propaganda at Rome in the Fourth and Fifth Centuries. A Study in Early Christian Iconography and Iconology, Oxford 1982

Ihm, Max, Die Epigramme des Damasus, in: RhM, n. F., 50, 1895, 191-204

Inglebert, Hervé, „L'histoire de Rome“ dans l'antiquité tardive: un concept équivoque, in: Latomus 55, 1996, 544-567 (zit. Inglebert 1996 [a])

Ioppolo, Giovanni, La struttura architettonica, in: La villa di Massenzio sulla via Appia. Il circo, hrsg. von Giovanni Ioppolo/Giuseppina Pisani Sartorio, Rom 1999, 103-196

Jacob, Benno, Beiträge zu einer Einleitung in die Psalmen, in: ZAW 17, 1897, 48-80

Jacques, François/Scheid, John, Rom und das Reich in der Hohen Kaiserzeit, 44 v. Chr. - 260 n. Chr., Bd. 1: Die Struktur des Reiches, Stuttgart/Leipzig 1998

Jaeger, Friedrich/Liebsch, Burkhard, Einführung, in: Handbuch der Kulturwissenschaften, Bd. 1: Grundlagen und Schlüssselbegriffe, hrsg. von Friedrich Jaeger/Burkhard Liebsch, Stuttgart/Weimar 2004, IX-XIII

James, N. W., Leo the Great and Prosper of Aquitaine: A Fifth Century Pope and his Adviser, in: JThS, n. s. 44, 1993, 554-584

Janssen, Harry, Kultur und Sprache. Zur Geschichte der alten Kirche im Spiegel der Sprachentwicklung von Tertullian bis Cyprian, Nijmegen 1938

Janssens, Jos, Vita e morte del cristiano negli epitaffi di Roma anteriori al sec. VII, Rom 1981

Jastrzebowska, Elisabeth, Les scènes de banquet dans les peintures et sculptures chrétiennes des IIIe et IVe siècles, in: RecAug 14, 1979, 3-90 
Jastrzebowska, Elisabeth, Untersuchungen zum altchristlichen Totenmahl aufgrund der Monumente des 3. und 4. Jahrhunderts unter der Basilika des heiligen Sebastian in Rom, Frankfurt a. M. 1981

Jastrzebowska, Elisabeth, S. Sebastiano, la più antica basilica cristiana di Roma, in: Ecclesiae urbis. Atti del Congresso internazionale di studi sulle chiese di Roma (IV-X secolo), hrsg. von Federico Guidobaldi/Alessandra Guiglia Guidobaldi, Vatikanstadt 2002, Bd. 2, 1141-1156

Jenal, Georg, Italia ascetica atque monastica. Das Asketen- und Mönchtum in Italien von den Anfängen bis zur Zeit der Langobarden (ca. 150/250 - 604), 2 Bde., Stuttgart 1995

Johnson, Mark J., Late Antique Imperial Mausolea, Diss. Princeton 1986

Johnson, Mark J., On the Burial Places of the Theodosian Dynasty, in: Byzantion 61, 1991, 330-339

Johnson, Mark J., The Fifth-Century Oratory of the Holy Cross at the Lateran in Rome, in: Architectura 25, 1995, 128-155

Johnson, Mark J., Pagan-Christian Burial Practices of the Fourth Century: Shared Tombs?, in: JECS 5, 1997, 37-59

Johnston, David E. L., The Roman Law of Trusts, Oxford 1988

Jones, Arnold H. M., The Later Roman Empire, 284-602. A Social, Economic and Administrative Survey, 2 Bde., Oxford 1964

de Jong, Mayke, Carolingian Monasticism: The Power of Prayer, in: The New Cambridge Medieval History, Bd. 2: c. 700 - c. 900, hrsg. von Rosamond McKitterick, Cambridge 1995, 622-653

Josi, Enrico, Coemeterium maius, in: RivAC 10, 1933, 7-16

Jost, Michael P. F., Die Patrozinien der Kirchen der Stadt Rom vom Anfang bis in das 10. Jahrhundert, 2 Bde., Neuried 2000

Jung, Michael, Marathon und Plataiai. Zwei Perserschlachten als „lieux de mémoire“ im antiken Griechenland, Göttingen 2006

Jungmann, Josef A., Missarum sollemnia. Eine genetische Erklärung der römischen Messe, 2 Bde., Wien 51962

Jungmann, Josef A., Von der „Eucharistia“ zur „Messe“, in: ZKTh 89, 1967, 29-40

Junyent, Eduard, Il Titolo di San Clemente in Roma, Rom 1932

Kader, Ingeborg, Heroa und Memorialbauten, in: Stadtbild und Bürgerbild im Hellenismus, hrsg. von Michael Wörrle/Paul Zanker, München 1995, 199-223

Kähler, Heinz, Konstantin 313, in: JDAI 67, 1952, 1-30 
Kähler, Heinz, Das Fünfsäulendenkmal für die Tetrarchen auf dem Forum Romanum, Köln 1964

Karpinski, Peter, Annua dies dormitionis. Untersuchungen zum christlichen Jahrgedächtnis der Toten auf dem Hintergrund antiken Brauchtums, Frankfurt a. M. 1987

Kennedy, Vincent L., The Pre-Gregorian hanc igitur, in: EL 50, 1936, 349-358

Kennedy, Vincent L., The Saints of the Canon of the Mass, Vatikanstadt 21963

Keppie, Lawrence, „Having been a Soldier“. The Commemoration of Military Service on Funerary Monuments of the Early Roman Empire, in: Documenting the Roman Army. Essays in Honour of Margaret Roxan, hrsg. von J. J. Wilkes, London 2003, $31-53$

Kierdorf, Wilhelm Funus und consecratio. Zu Terminologie und Ablauf der römischen Kaiserapotheose, in: Chiron 16, 1986, 43-69

Kierdorf, Wilhelm, Apotheose und postumer Triumph Trajans, in: Tyche 1, 1986, 147-156 (zit. Kierdorf 1986 [a])

Kirsch, Johann P., Die Lehre von der Gemeinschaft der Heiligen im christlichen Alterthum. Eine dogmengeschichtliche Studie, Mainz 1900

Kirsch, Johann P., Römische Martyrlegenden und altchristliche Kirchen Roms, in: Festschrift Georg v. Hertling zum 70. Geburtstag, Kempten/München 1913, 49-64

Kirsch, Johann P., Die römischen Titelkirchen im Altertum, Paderborn 1918

Kirsch, Johann P., I santuari domestici di martiri nei titoli romani ed altri simili santuari nelle chiese cristiane e nelle case private di fedeli, in: RPARA 2, 1923-1924, $27-$ 43

Kirsch, Johann P., Der stadtrömische christliche Festkalender im Altertum. Textkritische Untersuchungen zu den römischen „Depositiones“ und dem Martyrologium Hieronymianum, Münster 1924

Kirsch, Johann P., Die Grabstätte der Felices duo pontifices et martyres an der via Appia, in: RQA 33, 1925, 1-20

Kirsch, Johann P., Die Grabstätten der römischen Märtyrer und ihre Stellung im liturgischen Märtyrerkultus, in: RQA 38, 1930, 107-131

Kirschbaum, Engelbert, Die Gräber der Apostelfürsten. St. Peter und St. Paul in Rom, Frankfurt a. M. 31974

Kjærgaard, Jørgen, From memoria Apostolorum to basilica Apostolorum: On the Early Christian Cult-centre on the Via Appia, in: ARID 13, 1984, 59-76

Klauck, Hans-Josef, Die religiöse Umwelt des Urchristentums, 2 Bde., Stuttgart 19951996 
Klauser, Theodor, Die Cathedra im Totenkult der heidnischen und christlichen Antike, Münster 1927

Klauser, Theodor, Die konstantinischen Altäre der Lateranbasilika, in: RQA 43, 1935, 179-186

Klauser, Theodor, Die römische Petrustradition im Lichte der neuen Ausgrabungen unter der Peterskirche, Kön/Opladen 1956

Klein, Richard, Symmachus. Eine tragische Gestalt des ausgehenden Heidentums, Darmstadt 1971

Klein Richard, Zur heidnisch-christlichen Auseinandersetzung in Rom um die Wende vom 4. zum 5. Jahrhundert: Prudentius in Rom, in: RQA 98, 2003, 87-111

Koch, Hugo, Petrus und Paulus im zweiten Osterfeierstreit?, in: ZNW 19, 1919/1920, 174-179

Koch, Hugo, Cathedra Petri. Neue Untersuchungen über die Anfänge der Primatslehre, Gießen 1930

Kohns, Hans-Peter, Versorgungskrisen und Hungerrevolten im spätantiken Rom, Bonn 1961

Kolb, Frank, Diocletian und die erste Tetrarchie. Improvisation oder Experiment in der Organisation monarchischer Herrschaft?, Berlin/New York 1987

Kolb, Frank, Rom. Die Geschichte der Stadt in der Antike, München 1995

Kolb, Frank, Herrscherideologie in der Spätantike, Berlin 2001

König, Dorothee, Amt und Askese in der frühen Kirche. Priesteramt und Mönchtum bei den lateinischen Kirchenvätern der vorbenediktinischen Zeit, St. Ottilien 1985

Koep, Leo, s. v. „divus“, in: RAC 3, Stuttgart 1957, 1251-1257

Koep, Leo, Die Konsekrationsmünzen Kaiser Konstantins und ihre religionspolitische Bedeutung, in: JbAC 1, 1958, 94-104

Koskenniemi, Heikki, Studien zur Idee und Phraseologie des griechischen Briefes bis 400 n. Chr., Helsinki 1956

Koethe, Harald, Zum Mausoleum der weströmischen Dynastie bei Alt.-Sankt-Peter, in: $\operatorname{MDAI}(\mathrm{R})$ 46, 1931, 9-26

Kotila, Heikki, Memoria mortuorum. Commemoration of the Departed in Augustine, Rom 1992

Kötting, Bernhard, Bischofswahl in alter Zeit. Augustins Sorge und Bemühen um seinen Nachfolger im Bischofsamt, in: ders., Ecclesia peregrinans - das Gottesvolk unterwegs. Gesammelte Aufsätze, Bd. 1, Münster 1988, 405-408 
Kötting, Bernhard, Bischofsamt und Bischofswahl, in: ders., Ecclesia peregrinans das Gottesvolk unterwegs. Gesammelte Aufsätze, Bd. 1, Münster 1988, 467-479 (zit. Kötting 1988 [a])

Krause, Jens-Uwe, Das spätantike Städtepatronat, in: Chiron 17, 1987, 1-80

Krause, Jens-Uwe, Gefängnisse im Römischen Reich, Stuttgart 1996

Krautheimer, Richard, Mensa - Coemeterium - Martyrium, in: CArch 11, 1960, 15-40

Krautheimer, Richard, Zu Konstantins Apostelkirche in Konstantinopel, in: Mullus. Festschrift Theodor Klauser, hrsg. von Alfred Stuiber/Alfred Hermann, Münster 1964, 224-229

Krautheimer, Richard, The Crypt of Sta. Maria in Cosmedin and the Mausoleum of Probus Anicius, in: Essays in Memory of Karl Lehmann, hrsg. von Lucy Freeman Sandler, New York 1964, 171-175 (zit. Krautheimer 1964 [a])

Krautheimer, Richard, Intorno alla fondazione di San Paolo fuori le mura, in: RPARA 53-54, 1980-1982, 207-220

Krautheimer, Richard, Rom. Schicksal einer Stadt 312-1308, München 1987

Krautheimer, Richard, The Building Inscriptions and the Date of Construction of Old St. Peter's: A Reconsideration, in: RJ 25, 1989, 1-23

Krautheimer, Richard, The Ecclesiastical Building Policy of Constantine, in: Costantino il Grande. Dall'antichità all'umanesimo. Colloquio sul Cristianesimo nel mondo antico, Macerata 18.-20. Dezember 1990, hrsg. von Giorgio Bonamente/Franca Fusto, Bd. 2, Macerata 1993, 509-552

Krautheimer, Richard, Die Kirche S. Lorenzo in Damaso in Rom. Vorläufiger Grabungsbericht, in: Akten des 12. Internationalen Kongresses für Christliche Archäologie, Bonn 22.-28. 9. 1991, Bd. 2, Münster 1995, 958-963

Kretschmar, Georg, Die Theologie der Heiligen in der frühen Kirche, in: Aspekte frühchristlicher Heiligenverehrung (Oikonomia. Quellen und Studien zur orthodoxen Theologie 6), hrsg. von Fairy v. Lilienfeld u. a., Erlangen 1977, 77-125

Kretschmar, Georg, s. v. „Abendmahl III/1. Alte Kirche“, in: TRE 1, Berlin/New York 1977, 59-89 (zit. Kretschmar 1977 [a])

Kriegbaum, Bernhard, Die Religionspolitik des Kaisers Maxentius, in: AHP 30, 1992, 7-54

Krüger, Gustav, Lucifer, Bischof von Calaris, und das Schisma der Luciferianer, Leipzig 1886

Kuhoff, Wolfgang, Ein Mythos der römischen Geschichte: Der Sieg Konstantins des Großen über Maxentius vor den Toren Roms am 28. Oktober 312 n. Chr., in: Chiron 21, 1991, 127-174 
Künzle, Paul, Zur basilica Liberiana; basilica Sicinini = basilica Liberii, in: RQA 56, 1961, $1-61,129-166$

LaBranche, Carol L., Roma nobilis: The Public Architecture of Rome, 330-476, Evanston 1968

Ladner, Gerhart B., Die Papstbildnisse des Altertums und des Mittelalters, 3 Bde., Vatikanstadt 1941-1984

Lampe, Peter, Die stadtrömischen Christen in den ersten beiden Jahrhunderten, Tübingen 21989

Landwehr, Achim, Geschichte des Sagbaren. Einführung in die Historische Diskursanalyse, Berlin 2001

Landwehr, Achim/Stockhorst, Stefanie, Einführung in die Europäische Kulturgeschichte, Paderborn u. a. 2004

Lane Fox, Robin, Pagans and Christians, Harmondsworth 1986

Lanzoni, Francesco, La passio s. Sabini o Savini, in: RQA 17, 1903, 1-26

Lanzoni, Francesco, I titoli presbiteriali di Roma antica nella storia e nella leggenda, in: RivAC 2, 1925, 195-257

Lanzoni, Francesco, Le diocesi d'Italia dalle origini al principio del secolo VII (an. 604), 2 Bde., Faenza 1927

La Piana, George, The Roman Church at the End of the Second Century, in: HThR $18,1925,201-277$

Latte, Kurt, Römische Religionsgeschichte, München 1976

Lattimore, Richmond, Themes in Greek and Latin Epitaphs, Urbana 1942

Laum, Bernhard, Stiftungen in der griechischen und römischen Antike. Ein Beitrag zur antiken Kulturgeschichte, 2 Bde., Leipzig/Berlin 1914 (ND in einem Band Aalen 1964)

Lauwers, Michel, Le cimitière dans le moyen âge latin. Lieu sacré, saint et religieux, in: Annales. Histoire, Sciences Sociales 54, 1999, 1047-1072

Leeb, Rudolf, Konstantin und Christus. Die Verchristlichung der imperialen Repräsentation unter Konstantin dem Großen als Spiegel seiner Kirchenpolitik und seines Selbstverständnisses als christlicher Kaiser, Berlin/New York 1992

Lehmann, Tomas, Eine spätantike Inschriftensammlung und der Besuch des Papstes Damasus an der Pilgerstätte des hl. Felix in Cimitile/Nola, in: ZPE 91, 1992, 243281

Lehmann, Tomas, „Circus Basilicas”, coemeteria subteglata and Church Buildings in the suburbium of Rome, in: Rome AD 300-800. Power and Symbol - Image and Reality (AAAH 17), Rom 2003, 57-77 
Lepelley, Claude, Die Christen und das Römische Reich, in: Die Geschichte des Christentums. Religion - Politik - Kultur, Bd. 1: Die Zeit des Anfangs (bis 250), hrsg. von Luce Pietri, Freiburg 2003, 229-268

Liebeschuetz, John H. W. G., The Decline and Fall of the Roman City, Oxford 2001

Lietzmann, Hans, Petrus und Paulus in Rom. Liturgische und archäologische Studien, Bonn 21927

Lim, Richard, Unity and Diversity among Western Manichaeans: A Reconsideration of Mani's sancta ecclesia, in: REAug 35, 1989, 231-250

Lim, Richard, People as Power: Games, Munificence and Contested Topography, in: The Transformations of urbs Roma in Late Antiquity, hrsg. von William V. Harris, Rom 1999, 265-281

Lim, Richard, The Roman Pantomime Riot of A.D. 509, in: Humana sapit. Études d'antiquité tardive offertes à Lellia Cracco Ruggini, hrsg. von Jean-Michel Carrié/ Rita Lizzi Testa, Turnhout 2002, 35-42

Lind Hansen, Sanne, The Embellishment of Late-Antique domus in Ostia and Rome, in: Patron and Pavements in Late Antiquity, hrsg. von Signe Isager/Birte Poulsen, 1997, 111-124

Lindsay, Hugh, Eating with the Dead: The Roman Funerary Banquet, in: Meals in a Social Context. Aspects of the Communal Meal in the Hellenistic and Roman World, hrsg. von Inge Nielsen/Hanne S. Nielsen, Aarhus 1998, 67-80

Lindsay, Hugh, Death Pollution and Funerals in the City of Rome, in: Death and Disease in the Ancient City, hrsg. von Valerie M. Hope/Eireann Marshall, London 2000, 152-173

Lippold, Adolf, Ursinus und Damasus, in: Historia 14, 1965, 105-128

Lippold, Adolf, Bischof Ossius von Cordova und Konstantin der Große, in: ZKG 92, 1981, 1-15

Lipsius, Richard A., Chronologie der römischen Bischöfe bis zur Mitte des vierten Jahrhunderts, Kiel 1869

Liverani, Paolo, Le proprietà private nell'area lateranense fino all'età di Costantino, in: MEFRA 100, 1988, 891-915

Liverani, Paolo, Reimpiego senza ideologia. La lettura antica degli spolia dall'arco di Costantino all'età carolingia, in: $\mathrm{MDAI}(\mathrm{R})$ 111, 2004, 383-434

Lizzi, Rita, Vescovi e strutture ecclesiastiche nella città tardoantica (L'Italia Annonaria nel IV-V secolo d. C.), Como 1989

Lizzi Testa, Rita, Roma, Aquileia e Sirmium fra agiografia e fondazioni titolari, in: Studi Sancanzianesi in memoria di Mario Mirabella Roberti, hrsg. von Giuseppe Cuscito (AnAl 57), Triest 2004, 243-272 
Lizzi Testa, Rita, Senatori, popoli, papi. Il governo di Roma al tempo dei Valentiniani, Bari 2004 (zit. Lizzi Testa 2004 [a])

Llewellyn, Peter A. B., The Roman Church During the Laurentian Schism: Priests and Senators, in: $\mathrm{ChH} \mathrm{45,} \mathrm{1976,} \mathrm{417-427}$

Llewellyn, Peter A. B., The Names of the Roman Clergy, 401-1046, in: RSCI 35, 1981, 355-370

Lo Cascio, Elio, La popolazione, in: Roma imperiale. Una metropoli antica, hrsg. von Elio Lo Cascio, Rom 2000, 17-69

L'Orange, Hans P., Ein tetrarchisches Ehrendenkmal auf dem Forum Romanum, in: MDAI(R) 53, 1938, 1-34

L’Orange, Hans P./v. Gerkan, Arnim, Der spätantike Bildschmuck des Konstantinsbogens, Berlin 1939

Lucchesi, Giovanni, Ancora sull'antico calendario italico, in: RSCI 32, 1978, 140-152

Ludwig, Joseph, Die Primatworte Mt. 16, 18.19 in der altkirchlichen Exegese, Münster 1952

Luiselli, Bruno, In margine al problema della traslazione delle ossa di Pietro e Paolo, in: MEFRA 98, 1986, 843-854

Luraghi, Nino, Local Knowledge in Herodotus' Histories, in: The Historian's Craft in the Age of Herodotus, hrsg. von Nino Luraghi, Oxford 2001, 138-160

Luschi, Lizia, L'iconografia dell'edificio rotondo nella monetazione massenziana e il „tempio del divo Romolo“, in: BCAR 89, 1984, 41-54

Luschi, Lizia/Ceccherelli, A., Mausoleo „dei Gordiani“ e adiacente basilica (circ. VI), in: BCAR 92, 1987-88, 421-427

Lusiardi, Ralf, Stiftung und Seelenheil in den monotheistischen Religionen des mittelalterlichen Europa. Eine komparative Problemskizze, in: Stiftungen in Christentum, Judentum und Islam vor der Moderne. Auf der Suche nach ihren Gemeinsamkeiten und Unterschieden in religiösen Grundlagen, praktischen Zwecken und historischen Transformationen, hrsg. von Michael Borgolte, Berlin 2005, 47-69

Maccarrone, Michele, Cathedra Petri und die Idee der Entwicklung des päpstlichen Primats vom 2. bis 4. Jahrhundert, in: Saeculum 13, 1962, 278-292

Maccarrone, Michele, Apostolicità, episcopato e primato di Pietro. Ricerche e testimonianze, Rom 1976

Maccarrone, Michele, Il vescovo Achilleo e le iscrizioni metriche di S. Pietro a Spoleto, in: Miscellanea Amato Pietro Frutaz, Rom 1978, 249-284

Maccarrone, Michele, Il pellegrinaggio a San Pietro e il giubileo del 1300, I.: I limina apostolorum, in: RSCI 34, 1980, 363-429 
Maccarrone, Michele, Sedes apostolica-vicarius Petri. La perpetuità del primato di Pietro nella sede e nel vescovo di Roma (secoli III-VIII), in: Il primato del vescovo di Roma nel primo millennio. Ricerche e testimonianze, hrsg. von Michele Maccarone, Vatikanstadt 1991, 275-362

MacCormack, Sabine G., Art and Ceremony in Late Antiquity, Berkeley 1981

Mackie, Gillian, A New Look at the Patronage of Santa Costanza, Rome, in: Byzantion 67, 1997, 383-406

Mackie, Gillian, Early Christian Chapels in the West. Decoration, Function, and Patronage, Toronto u. a. 2003

Maier, Harry O., The Topography of Heresy and Dissent in Late-Fourth-Century Rome, in: Historia 44, 1995, 232-249

Manacorda, Daniele, Trasformazioni dell'abitato nel Campo Marzio: l'area della „Porticus Minucia“, in: La storia economica di Roma nell'alto Medioevo alla luce dei recenti scavi archeologici, hrsg. von Lidia Paroli/Paolo Delogu, Florenz 1993, $31-51$

Mango, Cyril, Constantine's Mausoleum and the Translation of Relics, in: ByzZ 83, 1990, 51-62 u. 443

Mara, Maria G., Contributo allo studio della Passio Anthimi, Rom 1964

Marasco, Gabriele, Costantino e le uccisioni di Crispo e Fausta (326 d. C.), in: RFIC 121, 1993, 297-317

Marazzi, Federico, I patrimonia sanctae romanae ecclesiae nel Lazio (secoli IV-X). Struttura amministrativa e prassi gestionali, Rom 1998

Marichal, Robert, Les dates des graffiti de Saint-Sébastien, in: CRAI 1953, 60-68

Markschies, Christoph, Wer schrieb die sogenannte Traditio Apostolica? Neue Beobachtungen und Hypothesen zu einer kaum lösbaren Frage aus der altkirchlichen Literaturgeschichte, in: Wolfram Kinzig/Christoph Markschies/Markus Vinzent, Tauffragen und Bekenntnis. Studien zur sogenannten Traditio Apostolica, zu den Interrogationes de fide und zum „Römischen Glaubensbekenntnis“, Berlin/New York 1999, 1-74

Markus, Robert A., Paganism, Christianity and the Latin Classics in the Fourth Century, in: Latin Literature of the Forth Century, hrsg. von James W. Binns, London 1974, 1-21

Markus, Robert A., The End of Ancient Christianity, Cambridge 1990

Markus, Robert A., Why on Earth could Places become Holy? Origins of the Christian Idea of Holy Places, in: JECS 2, 1994, 257-271

Marone, Paola, Pietro e Paolo e il loro rapporto con Roma nella letteratura antidonatista, in: Pietro e Paolo. Il loro rapporto con Roma nelle testimonianze antiche, Rom 2001, 457-472 
Marrou, Henri-Irénée, Survivances païennes dans les rites funéraires des donatistes, in: Hommages à Joseph Bidez et à Franz Cumont, Brüssel o. J. (1949), 193-203

Martin, Jochen, Zum Selbstverständnis, zur Repräsentation und Macht des Kaisers in der Spätantike, in: Saeculum 35, 1984, 115-131

Martin, Jochen, Die Macht der Heiligen, in: Christentum und antike Gesellschaft, hrsg. von Jochen Martin/Barbara Quint, Darmstadt 1990, 440-474

Martin, Jochen, Aspekte antiker Staatlichkeit, in: Staat und Staatlichkeit in der frühen römischen Republik, hrsg. von Walter Eder, Stuttgart 1990, 220-232 (zit. Martin 1990 [a])

Martin, Jochen, Der Verlust der Stadt, in: Die okzidentale Stadt nach Max Weber. Zum Problem der Zugehörigkeit in Antike und Mittelalter, hrsg. von Christian Meier, München 1994, 95-114

Martin, Jochen, Spätantike und Völkerwanderung, München ${ }^{31995}$

Martin, Jochen, Familie, Verwandtschaft und Staat in der römischen Republik, in: Res publica reperta. Zur Verfassung und Gesellschaft der römischen Republik und des frühen Prinzipats. Festschrift für Jochen Bleicken zum 75. Geburtstag, hrsg. von Jörg Spielvogel, Stuttgart 2002, 13-24

Martin, Jochen, Rom und die Heilsgeschichte. Beobachtungen zum Triumphbogenmosaik von S. Maria Maggiore in Rom, in: Jahrbuch des Historischen Kollegs 2003, 3-36

Martínez-Fazio, Luis M., La segunda basílica de San Pablo extramuros. Estudios sobre su fondación, Rom 1972

Martorelli, Rossana, S. Andrea in Vincis (Roma): domus ecclesiae o oratorio privato?, in: Domum tuam dilexi. Miscellanea in onore di Aldo Nestori, hrsg. von Federico Guidobaldi, Vatikanstadt 1998, 571-586

Marucchi, Orazio, Di una iscrizione storica che può attribuirsi alla basilica apostolorum sulla via Appia, in: NBAC 27, 1921, 61-69

Mattei, Paul, Habere ius sacerdotis. Sacerdoce et laïcat au témoignage de Tertullien de exhortatione castitatis et de monogamia, in: RSR 59, 1985, 200-221

Matthews, John F., The Poetess Proba and Fourth-Century Rome: Questions of Interpretation, in: Institutions, société et vie politique dans l'empire romain au IVe siècle ap. J.-C., hrsg. von Michel Cristol u. a., Rom 1992, 277-304

Maurice, Jules, Numismatique constantinienne, 3 Bde., Paris 1908-1912

Maurin, Jean, Funus et rites de séparation, in: AION(archeol) 6, 1984, 191-208

Mauss, Marcel, Die Gabe. Form und Funktion des Austausches in archaischen Gesellschaften, Frankfurt a. M. 1968 (Essai sur le don, Paris 1950) 
Mayer, Adalbert, Triebkräfte und Grundlinien des Entstehung des Meßstipendiums, St. Ottilien 1976

Mayer, Emanuel, Rom ist dort, wo der Kaiser ist. Untersuchungen zu den Staatsdenkmälern des dezentralisierten Reiches von Diocletian bis zu Theodosius II., Mainz 2002

Mazzarino, Santo, Il pensiero storico classico, Bd. II 2, Bari 1966

Mazzoleni, Danilo, Origine e cronologia dei monogrammi: riflessioni nelle iscrizioni dei Musei Vaticani, in: Le iscrizioni dei cristiani in Vaticano: materiali e contributi scientifici per una mostra epigrafica (Inscriptiones Sanctae Sedis, Bd. 2), hrsg. von Ivan DiStefano Manzella, Vatikanstadt 1997, 165-171

Mazzoleni, Danilo, Die Inschriften in den römischen Katakomben, in: Vincenzo Fiocchi Nicolai/Fabio Bisconti/Danilo Mazzoleni, Roms christliche Katakomben. Geschichte - Bilderwelt - Inschriften, Regensburg 1998, 147-185

McCormick, Michael, Eternal Victory. Triumphal Rulership in Late Antiquity, Byzantium, and the Early Medieval West, Cambridge 1986

McCulloh, John M., The Cult of Relics in the Letters and 'Dialogues' of Pope Gregory the Great: A Lexicographical Study, in: Traditio 32, 1976, 145-184

McGowan, Andrew, Discipline and Diet: Feeding the Martyrs in Roman Carthage, in: HThR 96, 2003, 455-476

McKitterick, Rosamond, The Carolingians and the Written Word, Cambridge 1989

McLynn, Neil B., The ,Apology' of Palladius: Nature and Purpose, in: JThS n.s. 42, 1991, $52-76$

McLynn, Neil B., Christian Controversy and Violence in the Fourth Century, in: Kodai 3, 1992, 15-44

McLynn, Neil B., Ambrose of Milan. Church and Court in a Christian Capital, Berkeley u. a. 1994

Meeks, Wayne A., The First Urban Christians. The Social World of the Apostle Paul, New Haven/London 1983

van der Meer, Frederik, Augustinus der Seelsorger. Leben und Wirken eines Kirchenvaters, Köln 21951

Meier, Christian, Kontinuität - Diskontinuität im Übergang von der Antike zum Mittelalter, in: Kontinuität - Diskontinuität in den Geisteswissenschaften, hrsg. von Hans Trümpy, Darmstadt 1973, 53-94

Meier, Hans-Rudolf, Alte Tempel - neue Kulte. Zum Schutz obsoleter Sakralbauten in der Spätantike und zur Adaption alter Bauten an den christlichen Kult, in: Innovation in der Spätantike, hrsg. von Beat Brenk, Wiesbaden 1996, 363-376 
Melucco Vaccaro, Alessandra, L'arco dedicato a Costantino. Analisi e datazione della decorazione architettonica. Con un contributo di Dora Cirone, in: MDAI(R) 108, 2001, 57-82

Meneghini, Roberto/Santangeli Valenzani, Riccardo, Sepolture intramuranee e paesaggio urbano a Roma tra V e VII secolo, in: La storia economica di Roma nell' alto Medioevo alla luce dei recenti scavi archeologici, hrsg. von Lidia Paroli/Paolo Delogu, Florenz 1993, 89-111

Meneghini, Roberto/Santangeli Valenzani, Riccardo, Sepolture intramuranee a Roma tra V e VII secolo d. C. - aggiornamenti e considerazioni, in: Archeologia Medievale $22,1995,283-290$

Meneghini, Roberto/Santangeli Valenzani, Riccardo Roma nell'altomedioevo. Topografia e urbanistica della città dal V al X secolo, Rom 2004

Merk, Karl J., Die meßliturgische Totenehrung in der römischen Kirche. Zugleich ein Beitrag zum mittelalterlichen Opferwesen. 1. Teil, Stuttgart 1926

Merkt, Andreas, Maximus I. von Turin. Die Verkündigung eines Bischofs der frühen Reichskirche im zeitgeschichtlichen, gesellschaftlichen und liturgischen Kontext, Leiden u. a. 1997

Mesnard, Maurice, La basilique de Saint Chrysogone à Rome, Vatikanstadt 1935

Metzger, Marcel, Les sacramentaires, Turnhout 1994

Metzger, Marcel, Geschichte der Liturgie, Paderborn 1998

Meyer, Hans B., Eucharistie. Geschichte, Theologie, Pastoral (Handbuch der Liturgiewissenschaft 4), Regensburg 1989

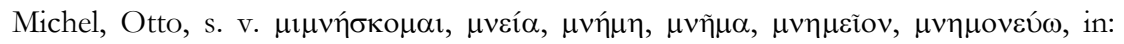
Theologisches Wörterbuch zum Neuen Testament, hrsg. von Gerhard Kittel, Bd. 4, Stuttgart 1942, 678-687

Mielsch, Harald, Zur stadtrömischen Malerei des 4. Jahrhunderts n. Chr., in: MDAI(R) 85, 1978, 151-207

Millar, Fergus, The Emperor in the Roman World (31 BC - AD 337), London 21992

Mittag, Franz P., Alte Köpfe in neuen Händen. Urheber und Funktion der Kontorniaten, Bonn 1999

Mohlberg, Leo K., Historisch-kritische Bemerkungen zum Ursprung der sogenannten Memoria Apostolorum an der Appischen Straße, in: Colligere fragmenta, Festschrift Alban Dold zum 70. Geburtstag, Beuron 1952, 52-74

Mohlberg, Leo K./Baumstark, Anton, Die älteste erreichbare Gestalt des Liber Sacramentorum anni circuli der römischen Kirche (Cod. Pad. D 47, fol. 11 ${ }^{\mathrm{r}}-100^{\mathrm{r}}$ ), Münster 1927 
Mohrmann, Christine, Locus refrigerii, in: Bernard Botte/Christine Mohrmann, L'ordinaire de la Messe. Texte critique, traduction et études, Paris/Löwen 1953, 123-132 (ND in: dies., Études sur le latin des chrétiens II: Latin chrétien et médiéval, Rom 1961, 81-91)

Molthagen, Joachim, Der römische Staat und die Christen im zweiten und dritten Jahrhundert, Göttingen 21975

Momigliano, Arnaldo, The Place of Herodotus in the History of Historiography, in: ders., Secondo contributo alla storia degli studi classici, Rom 1960, 29-44

Mommsen, Theodor, Die ludi magni und romani, in: RhM 14, 1859, 79-87 (erweiterter Nachdruck, in: ders., Römische Forschungen, Bd. 2, Berlin 1879, 42-57; danach zit. Mommsen 1879)

Mommsen, Theodor, Die römischen Bischöfe Liberius und Felix II., in: DZGW, n. s. $1,1896,167-179$

Monachino, Vincenzo, Il primato nello scisma donatista, in: AHP 2, 1964, 7-44

Monfrin, Françoise, Introduction, in: Albert Dufourcq, Étude sur les gesta martyrum romains, Bd. 5 : Les légendes grecques et les légendes latines, Paris 1988, IX-LII

Moorhead, John, Theoderic in Italy, Oxford 1992

v. Moos, Peter, Das Öffentliche und das Private im Mittelalter. Für einen kontrollierten Anachronismus, in: Das Öffentliche und das Private in der Vormoderne, hrsg. von Gert Melville/Peter von Moos, Köln u. a. 1998, 3-83

Morey, Charles R., The Gold-Glass Collection of the Vatican Library. With Additional Catalogues of other Gold-Glass Collections, hrsg. von Guy Ferrari, Vatikanstadt 1959

Morin, Germain, Études, textes, découverts. Contributions à la littérature et à l'histoire des douze premiers siècles, Bd. 1, Paris 1913

Morris, Ian, Death-Ritual and Social Structure in Classical Antiquity, Cambridge 1992

Mratschek, Sigrid, Der Briefwechsel des Paulinus von Nola. Kommunikation und soziale Kontakte zwischen christlichen Intellektuellen, Göttingen 2002

Mrozek, Stanislaw, Munificentia privata in den Städten Italiens der spätrömischen Zeit, in: Historia 27, 1978, 355-368

Mrozek, Stanislaw, Les distributions d'argent et de nourriture dans les villes italiennes du Haut-Empire romain, Brüssel 1987

Muhlberger, Steven, The Fifth-Century Chroniclers. Prosper, Hydatius, and the Gallic Chronicler of 452, Leeds 1990

Müller, Karl, Kleine Beiträge zur alten Kirchengeschichte: Parochie und Diözese im Abendland in spätrömischer und merowingischer Zeit, in: ZNW 32, 1933, 149-185 
Muschiol, Gisela, Famula Dei. Zur Liturgie in merowingischen Frauenklöstern, Münster 1994

Neri, Valerio, Medius princeps. Storia e immagine di Costantino nella storiografia latina pagana, Bologna 1992

Neri, Valerio, L'usurpatore come tiranno nel lessico politico della tarda antichità, in: Usurpationen in der Spätantike, hrsg. von François Paschoud/Joachim Szidat, Stuttgart 1997, 71-86

Neri, Valerio, L'abolizione dei munera gladiatoria e la datazione della passio Sebastiani, in: RSA 30, 2000, 217-223

Nesselhauf, Herbert, Patrimonium und res privata des römischen Kaisers, in: Bonner Historia Augusta Colloquium 2, Bonn 1964, 73-94

Nestori, Aldo, La Catacomba di Calepodio al III miglio dell'Aurelia vetus e i sepolcri dei papi Callisto I e Giulio I, in: RivAC 47, 1971, 169-278 und 48, 1972, 193-233

Nestori, Aldo, L'attività edilizia in Roma di papa Damaso, in: Saecularia damasiana. Atti del convegno internazionale per il XVI centenario della morte di papa Damaso I (11. 12. 384 - 10./12. 12. 1984), Vatikanstadt 1986, 161-172

Nestori, Aldo, La basilica anonima della via Ardeatina, Vatikanstadt 1990

Nestori, Aldo, Riflessioni sul luogo di culto cristiano precostantiniano, in: RivAC 75, 1999, 695-709

Nicolet, Claude, Introduction, in: Mégapoles méditerranéennes. Géographie urbaine retrospective, hrsg. von Claude Nicolet, Rom/Paris 2000, 11-20

Nieddu, Anna M., L'utilizzazione funeraria del suburbio nei secoli V e VI, in: Suburbium. Il suburbio di Roma dalla crisi del sistema delle ville a Gregorio Magno, hrsg. von Philippe Pergola u. a., Rom 2003, 545-606

Niero, Antonio, I martiri aquileiesi, in: Aquileia nel IV secolo (AnAl 22), Bd. 1, Udine 1982, 151-174

Niethammer, Lutz, Kollektive Identität. Heimliche Quellen einer unheimlichen Konjunktur, Reinbek 2000

Nippel, Wilfried, Introductory Remarks: Max Weber's „The City“ revisited, in: City States in Classical Antiquity and Medieval Italy, hrsg. von Anthony Molho u. a., Stuttgart 1991, 19-30

Niquet, Heike, Monumenta virtutum titulique. Senatorische Selbstdarstellung im spätantiken Rom im Spiegel der epigraphischen Denkmäler, Stuttgart 2000

Nock, Arthur D., Conversion. The Old and the New in Religion from Alexander the Great to Augustine of Hippo, Oxford 1933

Nock, Arthur D., The Cult of Heroes, in: HThR 37, 1944, 141-174

Nora, Pierre, Zwischen Geschichte und Gedächtnis, Berlin 1990 
Noethlichs, Karl-Leo, Die gesetzgeberischen Maßnahmen der christlichen Kaiser des vierten Jahrhunderts gegen Häretiker, Heiden und Juden (Diss. Köln 1971)

Novak, David M., Anicianae domus culmen, nobilitatis culmen, in: Klio 62, 1980, 473-493

Noy, David, Foreigners at Rome. Citizens and Strangers, London 2000

Nußbaum, Otto, Kloster, Mönch und Privatmesse. Ihr Verhältnis im Westen von den Anfängen bis zum hohen Mittelalter, Bonn 1961

Nußbaum, Otto, Die Aufbewahrung der Eucharistie, Bonn 1979

Odahl, Charles, Constantine and the Christian Empire, London/New York 2004

Orlandi, Silvia, Il Colosseo nel V secolo, in: The Transformations of urbs Roma in Late Antiquity, hrsg. von William V. Harris, Rom 1999, 249-263

Orselli, Alba M., L'idea e il culto del santo patrono cittadino nella letteratura latina cristiana, Bologna 1965

Osborne, John, The Roman Catacombs in the Middle Ages, in: PBSR 40, 1985, 278328

Osiek, Carolyn, The Widow as Altar: The Rise and Fall of a Symbol, in: SecCen 3, 1983, 159-169

Oexle, Otto G., Memoria und Memorialüberlieferung im früheren Mittelalter, in: FMSt 10, 1976, 70-95

Oexle, Otto G., Die Gegenwart der Toten, in: Death in the Middle Ages, hrsg. von Herman Braet/Werner Verbeke, Löwen 1983, 19-77

Oexle, Otto G., Memoria uns Memorialbild, in: Memoria. Der geschichtliche Zeugniswert des liturgischen Gedenkens im Mittelalter, hrsg. von Karl Schmid/ Joachim Wollasch, München 1984, 384-440

Oexle, Otto G., Mahl und Spende im mittelalterlichen Totenkult, in: FMSt 18, 1984, 401-420 (zit. Oexle 1984 [a])

Oexle, Otto G., Die Gegenwart der Lebenden und der Toten. Gedanken über Memoria, in: Gedächtnis, das Gemeinschaft stiftet, hrsg. von Karl Schmid, München/ Zürich 1985, 74-107

Oexle, Otto G., Memoria als Kultur, in: Memoria als Kultur, hrsg. von Otto G. Oexle, Göttingen 1995, 9-78

Palmer, Robert E. A., Roman Shrines of Female Chastity from the Caste Struggle to the Papacy of Innocent I, in: RSA 4, 1974, 113-159

Pani Ermini, Letizia, Testimonianze archeologiche di monasteri a Roma nell'alto medioevo, in: ASRSP 104, 1981, 25-45

Pani Ermini, Letizia, Forma Urbis e renovatio murorum in età teodericiana, in: Teoderico e i Goti tra Oriente e Occidente, Ravenna 1995, 171-180 u. 201-225 
Pani Ermini, Letizia, La civitas Leoniana, in: Dossiers d'Archéologie 217, 1996, 84-93

Pani Ermini, Letizia, Roma da Alarico a Teodosio, in: The Transformations of urbs Roma in Late Antiquity, hrsg. von William V. Harris, Rom 1999, 35-52

Pani Ermini, Letizia, Dai complessi martiriali alle civitates. Formazione e sviluppo dello spazio cristiano, in: La comunità cristiana di Roma. La sua vita e la sua cultura dalle origini all'alto medio evo, hrsg. von Letizia Pani Ermini/Paolo Siniscalco, Vatikanstadt 2000, 397-419

Parisi Presicce, Claudio, L'abbandono della moderazione. I ritratti di Costantino e della sua progenie, in: Costantino il Grande. La civiltà antica al bivio tra Occidente e Oriente, hrsg. von Angela Donati/Giovanni Gentili, Mailand 2005, 138-155

Parmegiani, Neda/Pronti, Alberto, Recenti scavi a S. Cecilia in Trastevere a Roma, in: Akten des 12. Internationalen Kongresses für Christliche Archäologie, Bonn 22.-28. 9. 1991, Bd. 2, Münster 1995, 1069-1075

Parmegiani, Neda/Pronti, Alberto, S. Cecilia in Trastevere. Nouvi scavi e ricerche, Vatikanstadt 2004

Paschoud, François, Zosime 2, 29 et la version païenne de la conversion de Constantin, in: Historia 20, 1971, 334-353

Paschoud, François, Ancora sul rifiuto di Costantino di salire al Campidoglio, in: Costantino il Grande. Dall'antichità all'umanesimo. Colloquio sul Cristianesimo nel mondo antico, Macerata 18.-20. Dezember 1990, hrsg. von Giorgio Bonamente/Franca Fusto, Bd. 2, Macerata 1993, 737-748

Paschoud, François, Zosime et Constantin. Nouvelles Controverses, in: MH 54, 1997, 9-28

Paterna, Claudia, Il circo Variano a Roma, in: MEFRA 108, 1996, 817-853

Patlagean, Evelyne, Pauvreté économique et pauvreté sociale à Byzance, 4-7e siècles, Paris 1977

Pavolini, Carlo, L'area del Celio fra l'antichità e il medioevo alla luce delle recenti indagini archeologiche, in: La storia economica di Roma nell'alto Medioevo alla luce dei recenti scavi archeologici, hrsg. von Lidia Paroli/Paolo Delogu, Florenz 1993, $53-70$

Pavolini, Carlo, La basilica costantiniana di S. Agnese. I resultati delle indagini dei restauri per il giubileo del 2000, in: Ecclesiae urbis. Atti del Congresso internazionale di studi sulle chiese di Roma (IV-X secolo), hrsg. von Federico Guidobaldi/Alessandra Guiglia Guidobaldi, Vatikanstadt 2002, Bd. 2, 1203-1224

Pellegrino, Michele, Le sens ecclésial du martyre, in: RSR 35, 1961, 151-175

Pensabene, Patrizio/Panella, Clementina, Reimpiego e progettazione architettonica nei monumenti tardo-antichi di Roma, in: RPARA 66, 1993-1994, 111-283 
Pergola, Philippe, Nereus et Achilleus martryres: L'intervention de Damase à Domitille (avec un appendice sur les résultats des fouilles récentes de la Basilique de Damase à Generosa), in: Saecularia Damasiana. Atti del convegno internazionale per il XVI centenario della morte di papa Damaso I (11. 12. 384 - 10./12. 12. 1984), Vatikanstadt 1986, 203-224

Pergola, Philippe,/Barbini, Palmira M., Le catacombe romane. Storia e topografia, Rom 21999

Pesarini, Santi, Contributo alla storia della basilica di San Lorenzo sulla via Tiburtina, in: Studi Romani 1, 1913, 37-52

Pesci, Benedetto, Il culto di san Sebastiano a Roma nell'antichità e nel medioevo, in: Antonianum 20, 1945, 177-200

Pétré, Hélène, Caritas. Étude sur le vocabulaire latin de la charité chrétienne, Löwen 1948

Philippart, Guy, Les légendiers latins et autres manuscrits hagiographiques, Turnhout 1977 und 1985 (Ergänzungen)

Philippart, Guy, Martirologi e leggendari, in: Lo spazio letterario del medioevo I: Il medioevo latino, Bd. 2: La circolazione del testo, hrsg. von Guglielmo Cavallo u. a., Rom 1994, 605-648

Picard, Jean-Charles, Etude sur l'emplacement des tombes des papes du IIIe au Xe siècle, in: MEFR 81, 1969, 725-782

Picard, Jean-Charles, Le souvenir des évêques. Sépultures, listes épiscopales et culte des évêques en Italie du Nord des origines au Xe siècle, Rom 1988

Pickert, Susanne, Die römischen Stiftungen der augusteischen Zeit, in: Stiftungen in Christentum, Judentum und Islam vor der Moderne. Auf der Suche nach ihren Gemeinsamkeiten und Unterschieden in religiösen Grundlagen, praktischen Zwecken und historischen Transformationen, hrsg. von M. Borgolte, Berlin 2005, 23-45

Piepenbrink, Karen, Christliche Identität und Assimilation in der Spätantike. Probleme des Christseins in der Reflexion der Zeitgenossen, Frankfurt a. M. 2005

Pietri, Charles, Concordia apostolorum et renovatio urbis (culte des martyrs et propaganda pontificale), in: MEFR 73, 1961, 275-322

Pietri, Charles, Le sénat, le peuple chrétien et les partis du cirque à Rome sous le pape Symmaque (498-514), in: MEFR 78, 1966, 123-139

Pietri, Charles, Roma christiana. Recherches sur l'Église de Rome, son organisation, sa politique, son idéologie de Miltiade à Sixte III (311-440), 2 Bde., Rom 1976

Pietri, Charles, Recherches sur les domus ecclesiae, in: REAug 24, 1978, 3-21

Pietri, Charles, Évergétisme et richesses ecclésiastiques dans l'Italie du IVe à la fin du Ve s.: l'exemple romain, in: Ktema 3, 1978, 317-337 (zit. Pietri 1978 [a]) 
Pietri, Charles, La mort en Occident dans l'épigraphie latine: de l'épigraphie païenne à l'épigraphie chrétienne, 3e - 6e siècles, in: MD 144, 1980, 25-48

Pietri, Charles, Donateurs et pieux établissements d'après le légendier romain (VeVIIe s.), in: Hagiographie, cultures et sociétés (IVe-XIIe siècles), Paris 1981, 435453

Pietri, Charles, Aristocratie et société cléricale dans l'Italie chrétienne au temps d'Odoacre et de Théodoric, in: MEFRA 93, 1981, 417-467 (zit. Pietri 1981 [a])

Pietri, Charles, Une aristocratie provinciale et la mission chrétienne: l'exemple de la Venetia, in: Aquileia nel IV secolo (AnAl 22), Bd. 1, Udine 1982, 89-137

Pietri, Charles, s. v. „Grabinschrift II (lateinisch)“, in: RAC 12, Stuttgart 1983, 514590

Pietri, Charles, s. v. „Graffito I (lateinisch)“, in: RAC 12, Stuttgart 1983, 637-667 (zit. Pietri 1983 [a])

Pietri, Charles, Liturgie, Kultur und Gesellschaft. Das Beispiel Roms in der ausgehenden Antike (4. - 5. Jahrhundert), in: Concilium 19, 1983, 116-124 (zit. Pietri 1983 [b])

Pietri, Charles, Les origines du culte des martyrs (d'après un ouvrage recent), in: RivAC 60, 1984, 293-319

Pietri, Charles, Damase évêque de Rome, in: Saecularia Damasiana. Atti del convegno internazionale per il XVI centenario della morte di papa Damaso I (11. 12. 384 10./12. 12. 1984), Vatikanstadt 1986, 31-58

Pietri, Charles, Régions ecclésiastiques et paroisses romaines, in: Actes du XIe congrès international d'archéologie chrétienne, Bd. 2, Rom 1989, 1035-1067

Pietri, Charles, L'évolution du culte des saints aux premiers siècles chrétiens: du témoin à l'intercesseur, in: Les fonctions des saints dans le monde occidental (IIIe XIIIe siècle) (Actes du colloque Rome, 27-29. 10 1988), Rom 1991, 15-36

Pietri, Charles/Pietri, Luce (Hgg.), Prosopographie chrétiennne du Bas-Empire, Bd. 2: Italie (313-604), Rom 1999

Pietri, Luce, Les abbés de basilique dans la Gaule du VIe siècle, in: RHEF 69, 1983, 528

Pietri, Luce, Évergétisme chrétien et fondations privées dans l'Italie de l'antiquité tardive, in: Humana sapit. Études de l'antiquité tardive offertes à Lellia Cracco Ruggini, hrsg. von Jean-Michel Carrié/Rita Lizzi Testa, Turnhout 2002, 253-263

Pietri, Luce/Duval, Yvette/Pietri, Charles, Peuple chrétien ou plebs: Le rôle des laïcs dans les élections ecclésiastiques en Occident, in: Institutions, société et vie politique dans l'empire romain au IVe siècle ap. J.-C., hrsg. von Michel Christol u. a., Rom 1992, 373-395

Piganiol, André, L’empereur Constantin, Paris 1932 
Pilsworth, Clare, Dating the Gesta martyrum: A Manuscript-Based Approach, in: Early Medieval Europe 9, 2000, 309-324

Pisani Sartorio, Giuseppina/Calza, Raissa, La villa di Massenzio sulla via Appia. Il palazzo - le opere d'arte, Rom 1976

Pocock, John G. A., The Concept of a Language and the métier d'historien: Some Considerations on Practice, in: The Languages of Political Theory in Early-Modern Europe, hrsg. von Anthony Pagden, Cambridge 1987, 19-38

Pohlkamp, Wilhelm, Textfassungen, literarische Formen und geschichtliche Funktionen der römischen Silvester-Akten, in: Francia 19, 1992, 115-196

Poschmann, Bernhard, Paenitentia secunda. Die kirchliche Buße im ältesten Christentum bis Cyprian und Origines. Eine dogmengeschichtliche Untersuchung, Bonn 1940

Poupon, Gérard, Tertullien et le privilège de Pierre (Note sur de Pudicitia 21, 9-10), in: REAug 32, 1986, 142-144

Prandi, Adriano, Il complesso monumentale della basilica celimontana dei SS. Giovanni e Paolo, Rom 1953

Price, Simon R. F., Between Man and God: Sacrifice in the Roman Imperial Cult, in: JRS 70, 1980, 28-43

Price, Simon R. F., Rituals and Power. The Roman Imperial Cult in Asia Minor, Cambridge 1984

Price, Simon R. F., Gods and Emperors: The Greek Language of the Roman Imperial Cult, in: JHS 104, 1984, 79-95 (zit. Price 1984 [a])

Price, Simon R. F., From Noble Funerals to Divine Cult: The Consecration of Roman Emperors, in: Rituals of Royalty. Power and Ceremonial in Traditional Societies, hrsg. von David Cannadine/Simon Price, Cambridge 1987, 56-105

Prinz, Friedrich, Frühes Mönchtum im Frankenreich. Kultur und Gesellschaft in Gallien, den Rheinlanden und Bayern am Beispiel der monastischen Entwicklung (4. bis 8. Jahrhundert), München 21988

Purcell, Nicholas, The Populace of Rome in Late Antiquity: Problems of Classification and Historical Description, in: The Transformations of urbs Roma in Late Antiquity, hrsg. von William V. Harris, Rom 1999, 135-161

Quasten, Johannes, Vetus superstitio et nova religio. The Problem of Refrigerium in the Ancient Chuch of North Africa, in: HThR 33, 1940, 253-266

Quasten, Johannes, Mysterium tremendum. Eucharistische Frömmigkeitsauffassungen des vierten Jahrhunderts, in: Vom christlichen Mysterium. Gesammelte Arbeiten zum Gedächtnis von Odo Casel, hrsg. von Anton Mayer u. a., Düsseldorf 1951, 66-75

Quentin, Henri, Les martyrologes historiques du Moyen Âge. Étude sur la formation du martyrologe romain, Paris 1908 
Quinn, Naomi/Holland, Dorothy, Culture and Cognition, in: Cultural Models in Language and Thought, hrsg. von Naomi Quinn/Dorothy Holland, Cambridge $1987,3-40$

Ramsey, Boniface, Almsgiving in the Latin Church: The Late Fourth and Early Fifth Centuries, in: ThS 43, 1982, 226-259

Rapisarda, Grazia, Primato di Pietro in Gaudenzio di Brescia (trattato 16, 9-10), in: Politica retorica e simbolismo del primato: Roma e Costantinopoli (secoli IV-VII), hrsg. von Febronia Elia, Bd. 1, Catania 2002, 107-118

Rasch, Jürgen J., Das Maxentius-Mausoleum an der via Appia in Rom, Mainz 1984

Rasch, Jürgen J., Zur Rekonstruktion der Andreasrotunde an Alt-St.-Peter, in: RQA 85, 1990, 1-18

Rasch, Jürgen J., Das Mausoleum bei Tor de’ Schiavi in Rom, Mainz 1993

Rasch, Jürgen J., Das Mausoleum der Kaiserin Helena in Rom und der „Tempio della Tosse" in Tivoli, Mainz 1998

Rea, Rossella, Roma: l'uso funerario della valle del Colosseo tra tardo antico e alto medioevo, in: Archeologia Medievale 20, 1993, 645-658

Rebenich, Stefan, Hieronymus und sein Kreis. Prosopographische und sozialgeschichtliche Untersuchungen, Stuttgart 1992

Rebenich, Stefan, Vom dreizehnten Gott zum dreizehnten Apostel? Der tote Kaiser in der Spätantike, in: ZAC 4, 2000, 300-324

Rebenich, Stefan, Viri nobiles, Viri diserti, Viri locupletes. Von der heidnischen zur christlichen Patronage im vierten Jahrhundert, in: Christen und Nichtchristen in Spätantike, Neuzeit und gegenwart. Beginn und Ende des Konstantinischen Zeitalters, Internationales Kolloquium aus Anlaß des 65. Geburtstags von Adolf M. Ritter, hrsg. von Angelika Dörfler-Dierken/Wolfram Kinzig/Markus Vinzent, Mandelbachtal/Cambridge 2001, 61-80

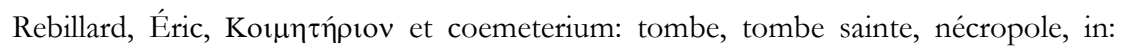
MEFRA 105, 2, 1993, 975-1001

Rebillard, Éric, L'église de Rome et le développement des catacombes. À propos de l'origine des cimitières chrétiens, in: MEFRA 109, 2, 1997, 741-763

Rebillard, Éric, Église et sépulture dans l'antiquité tardive (Occident latin, 3e - 6e siècles,), in: Annales. Histoire, Sciences Sociales 54, 1999, 1027-1046

Rebillard, Éric, Violations de sépulture et impiété dans l'antiquité tardive, in: Impies et paiens entre Antiquité et Moyen Age, hrsg. von Lionel Mary/Michel Sot, Paris 2002, 65-80

Rebillard, Éric, Religion et sépulture. L'Église, les vivants et les morts dans l'Antiquité tardive, Paris 2003 
Reekmans, Louis, L'implantation monumentale chrétienne dans la zone suburbaine de Rome du IVe au IXe siècle, in: RivAC 44, 1968, 173-207

Reekmans, Louis, Le développement topographique de la région du Vatican à la fin de l'antiquité et au début du Moyen Âge (300-850), in: Mélanges d'archéologie et d'histoire de l'art offerts à Jacques Lavalleye, Löwen 1970, 197-235

Reekmans, Louis, L'implantation monumentale chrétienne dans le paysage urbain de Rome de 300 à 850, in: Actes du XIe congrès international d'archéologie chrétienne, Bd. 2, Vatikanstadt 1989, 861-915

Reekmans, Louis, Recherches récentes dans les cryptes des martyrs romains, in: Martyrium in Multidisciplinary Perspective. Memorial Louis Reekmans, hrsg. von Mathijs Lamberigts/Peter van Deun, Löwen 1995, 31-70

Reicke, Bo, Diakonie, Festfreude und Zelos in Verbindung mit der altchristlichen Agapenfeier, Wiesbaden 1951

Repertorium der christlich-antiken Sarkophage, Bd. 1: Rom und Ostia, hrsg. von Friedrich W. Deichmann, bearb. von Giuseppe Bovini/Hugo Brandenburg, Wiesbaden 1967 (Ikonographisches Register, bearb. u, komm. von Ulrike Lange, Dettelbach 1996)

Reutter, Ursula, Damasus, Bischof von Rom (366-384). Leben und Werk, Diss. Jena 1999

Reynaud, Jean-François, Aux origines des paroisses, in: Alle origini della parrocchia rurale (IV-VIII sec.), hrsg. von Philippe Pergola, Vatikanstadt 1999, 83-100

Ricciardi, Monica, Nuove ricerche sul battistero nella catacomba di Ponziano a Roma, in: L'edificio battesimale in Italia. Aspetti e problemi (Atti dell' VIII Congresso Nazionale di Archeologia Cristiana), Bordighera 2001, Bd. 2, 957-974

Richard, Jean-Claude, Tombeaux des empereurs et temples des divi: notes sur la signification religieuse des sépultures impériales à Rome, in: RHR 170, 1966, 127 142

Richard, Jean-Claude, Les funérailles de Trajan et le triomphe sur les Parthes, in: REL 44, 1966, 351-362 (zit. Richard 1966 [a])

Richard, Jean-Claude, Recherches sur certains aspects du culte impérial. Le funéraire des empereurs romains aux deux premiers siècles de notre ère, in: ANRW II 16, 2, Berlin/New York 1978, 1121-1134

Richard, Marcel, La lettre Confidimus quidem du Pape Damase, in: AIPhO 11, 1951, 323-340

Riggsby, Andrew M., ,Public' and ,Private' in Roman Culture: The Case of the cubiculum, in: JRA 10, 1997, 36-56

Rilinger, Rolf, Domus und res publica. Die politisch-soziale Bedeutung des aristokratischen „Hauses“ in der späten römischen Republik, in: Zwischen „Haus“ 
und „Staat“. Antike Höfe im Vergleich, hrsg. von Aloys Winterling, München 1997, 73-90

Ristow, Sebastian, Frühchristliche Baptisterien, Münster 1998

Ronchey, Silvia, Les procès-verbaux des martyres chrétiens dans les acta martyrum et leur fortune, in: MEFRA 112, 2000, 723-752

Rordorf, Willy, La „diaconie“ des martyrs selon Origène, in: Epektasis. Mélanges patristiques offerts au cardinal Jean Daniélou, hrsg. von Jacques Fontaine/Charles Kannengiesser, Paris 1972, 395-402

Rousselle, Aline, Aspects sociaux du recrutement ecclésiastique au IVe siècle, in: MEFRA 89, 1977, 333-370

Rüpke, Jörg, Kalender und Öffentlichkeit. Die Geschichte der Repräsentation und religiösen Qualifikation von Zeit in Rom, Berlin/New York 1995

Rüpke, Jörg, Die Religion der Römer. Eine Einführung, München 2001

Rush, Alfred C., Death and Burial in Christian Antiquity, Washington D. C. 1941

Rutgers, Leonard V., The Jews in Late Ancient Rome. Evidence of Cultural Interaction in the Roman Diaspora, Leiden 1995

Ruysschaert, José, Essai d'interprétation synthétique de l'Arc de Constantin, in: RPARA 35, 1962-1963, 79-100

Ruysschaert, José, À propos de quelques textes romains du IVe s. relatifs à Pierre et Paul, in: AHP 7, 1969, 7-41

Ruysschaert, José, Pierre et Paul à Rome. Textes et contextes d'une inscription damasienne, in: RPARA 42, 1969-1970, 201-218

Ruysschaert, José, La légendaire sedes pétrienne du maius, in: RivAC 49, 1973, 293-297

Sághy, Marianne, Patrons and Priests. The Roman Senatorial Aristocracy and the Church A. D. 355-384, Diss. Princeton 1998

Sághy, Marianne, Prayer at the Tomb of the Martyrs? The Damasan Epigrams, in: La preghiera nel tardo antico. Dalle origini ad Agostino, Rom 1999, 519-537

Sághy, Marianne, Scinditur in partes populus: Pope Damasus and the Martyrs of Rome, in: Early Medieval Europe 9, 2000, 273-287

Saint-Roch, Patrick, Le cimitière de Basileus ou coemiterium sanctorum Marci et Marcelliani Damasique, Vatikanstadt 1999

Saller, Richard P., Personal Patronage under the Early Empire, Cambridge 1982

Salomonson, Jan W., Chair, Sceptre and Wreath. Historical Aspects of their Representation on some Roman Sepulcral Monuments, Proefschrift Groningen 1956

Saltet, Louis, La formation de la légende des papes Libère et Félix, in: BLE, ser. 3, 7, 1905, 222-236 
Salzman, Michele R., On Roman Time. The Codex-Calendar of 354 and the Rhythms of Urban Life in Late Antiquity, Berkeley u. a. 1990

Salzman, Michele R., The Christianisation of Sacred Time and Sacred Space, in: The Transformations of urbs Roma in Late Antiquity, hrsg. von William V. Harris, Rom 1999, 123-134

Salzman, Michele R., The Making of a Christian Aristocracy. Social and Reliqgious Change in the Western Roman Empire, Cambridge (Mass.) 2002

Sanders, Gabriel, Les chrétiens face à l'épigraphie funéraire latine, in: ders., Lapides memores. Païens et chrétiens face à la mort: le témoignage de l'épigraphie funéraire latine, hrsg. von Angela Donati u. a., Faenza 1991, 131-153 (ND aus: Assimilation et résistance à la culture gréco-romaine dans le monde ancien. Travaux du VIe Congrès Internationel d'Études Classiques, Madrid 1974, Bukarest/Paris 1976, 283 299)

Santangeli Valenzani, Riccardo, Pellegrini, senatori e papi. Gli xenodochia a Roma tra il V e il IX secolo, in: RIA, ser. III, 19-20, 1996-1997, 203-226

Santangeli Valenzani, Riccardo, Il paesaggio urbano altomedievale nei testi del Liber Pontificalis, in: Atti del colloquio internazionale „Il Liber Pontificalis e la storia materiale" (MNHIR 60/61 [2001-2002]), hrsg. von Herman Geertman, Rom 2003, 225-234

Sardella, Teresa, Società chiesa e stato nell'età di Teoderico. Papa Simmaco e lo scisma laurenziano, Soveria Mannelli 1996

Saxer, Victor, Morts, martyrs, reliques en Afrique chrétienne aux premiers siècles. Les témoignages de Tertullien, Cyprien, et Augustin à la lumière de l'archéologie africaine, Paris 1980

Saxer, Victor, Die Ursprünge des Märtyrerkultes in Afrika, in: RQA 79, 1984, 1-11

Saxer, Victor, Damase et le calendrier des fêtes de martyrs de l'Eglise romaine, in: Saecularia Damasiana. Atti del convegno internazionale per il XVI centenario della morte di papa Damaso I (11. 12. 384 - 10./12. 12. 1984), Vatikanstadt 1986, 59-88

Saxer, Victor, L'utilisation par la liturgie de l'espace urbain et suburbain: l'exemple de Rome dans l'antiquité et le haut moyen âge, in: Actes du XIe congrès international d'archéologie chrétienne, Bd. 2, Vatikanstadt 1989, 917-1033

Saxer, Victor, La questione di Ippolito romano: a proposito di un libro recente, in: Nuove ricerche su Ippolito, Rom 1989, 43-60 (zit. Saxer 1989 [a])

Saxer, Victor, Pilgerwesen in Italien und Rom im späten Altertum und Frühmittelalter, in: Akten des XII. Internationalen Kongresses für Christliche Archäologie, Bd. 1, Münster 1995, 36-57

Saxer, Victor, Sainte-Marie-Majeure. Une basilique de Rome dans l'histoire de la ville et de son église (Ve - XIIIe siécle), Rom 2001 
Saxer, Victor, La chiesa di Roma dal V al X secolo: amministrazione centrale e organizzazione territoriale, in: SSAM 48: Roma nell'Alto Medioevo, Spoleto 2001, Bd. 2, 493-637 (zit. Saxer 2001 [a])

Schäfer, Ernst, Die Bedeutung der Epigramme des Papstes Damasus I. für die Geschichte der Heiligenverehrung, Rom 1932

Schäfer, F., Die Acten der heiligen Nereus und Achilleus. Untersuchung über den Originaltext und die Zeit seiner Entstehung, in: RQA 8, 1894, 89-119

Scheid, John, Contraria facere: renversements et déplacements dans les rites funéraires, in: $\operatorname{AION}($ archeol) 6, 1984, 117-139

Scheid, John, Romulus et ses frères. Le collège des frères arvales, modèle du culte public dans la Rome des empereurs, Rom 1990

Scheid, John, Die Parentalien für die verstorbenen Caesaren als Modell für den römischen Totenkult, in: Klio 75, 1993, 188-201

Scheid, John, Les décrets de Pise et le culte des morts, in: La commemorazione di Germanico nella documentazione epigrafica. Tabula Hebana e Tabula Siarensis, hrsg. von Augusto Fraschetti, Rom 2000, 131-140

Schlinkert, Dirk, Vom Haus zum Hof. Aspekte höfischer Herrschaft in der Spätantike, in: Klio 78, 1996, 454-482

Schlumberger, Jörg A., Die Epitome de Caesaribus. Untersuchungen zur heidnischen Geschichtsschreibung des 4. Jahrhunderts n. Chr., München 1974

Schmid, Karl/Wollasch, Joachim, Die Gemeinschaft der Lebenden und Verstorbenen in Zeugnissen des Mittelalters, in: FMSt 1, 1967, 365-405

Schmid, Karl/Oexle, Otto G., Voraussetzungen und Wirkung des Gebetsbundes von Attigny, in: Francia 2, 1974, 71-122

Schmidt, Manfred G., Ambrosii carmen de obitu Probi. Ein Gedicht des Mailänder Bischofs in epigraphischer Überlieferung, in: Hermes 127, 1999, 99-116

Schmidt, Wilhem, Geburtstag im Altertum, Gießen 1908

Schmidt-Hofner, Sebastian, Die städtische Finanzautonomie im spätrömischen Reich, in: Staatlichkeit und politisches Handeln in der römischen Kaiserzeit, hrsg. von Hans-Ulrich Wiemer, Berlin/New York 2006, 209-248

Schmitt-Pantel, Pauline, Évergétisme et mémoire du mort. À propos des fondations de banquets publics dans les cités grecques à l'époque hellénistique et romaine, in: La mort, les morts dans les sociétés anciennes, hrsg. von Gherardo Gnoli/JeanPierre Vernant, Cambridge 1982, 177-188

Schneider, Alfons M., Refrigerium, Bd. 1: Nach literarischen Quellen und Inschriften, Freiburg 1928 
Schneider, Alfons M., Die Memoria Apostolorum an der Via Appia, NAWG.PH 1951, nr. 3

Schöllgen, Georg, Monepiskopat und monarchischer Episkopat. Eine Bemerkung zur Terminologie, in: ZNW 77, 1986, 146-151

Schöllgen, Georg, Probleme der frühchristlichen Sozialgeschichte. Einwände gegen Peter Lampes Buch „Die stadtrömischen Christen in den ersten beiden Jahrhunderten“, in: JbAC 32, 1989, 23-40

Schöllgen, Georg, Die Anfänge der Professionalisierung des Klerus und das kirchliche Amt in der syrischen Didaskalie, Münster 1998

v. Schoenebeck, Hans, Beiträge zur Religionspolitik des Maxentius und Constantin, Leipzig 1939

Schottroff, Willy, ,Gedenken' im Alten Orient und im Alten Testament. Die Wurzel zākar im semitischen Sprachkreis, Neukirchen-Vluyn 21967

Schulten, Peter N., Die Typologie der römischen Konsekrationsprägungen, Frankfurt a. M. 1979

Schulze, Winfried, Ortsbesichtigung: Deutsche Erinnerungsorte, in: GWU 54, 2003, 608-613

Schumacher, Leonhard, Zur ,Apotheose' des Herrschers in der Spätantike, in: Atti dell'Accademia Romanistica Costantiniana 10, 1995, 105-125

Schumacher, Walter N., Das Baptisterium von Alt-St. Peter und seine Probleme. Mit einem Beitrag von Thomas Barth, in: Studien zur spätantiken und byzantinischen Kunst. Friedrich Wilhelm Deichmann gewidmet, hrsg. in Verbindung mit Otto Feld/Urs Peschlow, Bd. 1, Bonn 1986, 215-233

Schumacher, Walter N., Die konstantinischen Exedra-Basiliken, in: Die Katakombe „Santi Marcellino e Pietro“. Repertorium der Malereien, hrsg. von Johannes G. Deckers u. a., Münster 1987, 132-186

Schwartz, Eduard, Die Kanonessammlungen der alten Reichskirche, in: ZSRG.K 25, 1936, $1-114$

Scrinari, Valnea S. M., Il Laterano imperiale, Bd. 2: Dagli horti Domitiae alla Cappella cristiana, Vatikanstadt 1995

Scullion, Scott, Olympian and Chthonian, in: ClAnt 13, 1994, 75-119

Seeliger, Hans R., Die Geschichte der Katakombe inter duos (!) lauros nach den schriftlichen Quellen, in: Johannes G. Deckers/Hans R. Seeliger/Gabriele Miethke, Die Katakombe „Santi Marcellino e Pietro“. Repertorium der Malerein. Textband, Vatikanstadt 1987, 59-90

Seider, Richard, Beiträge zur Geschichte und Paläographie der antiken Vergilhandschriften, in: Studien zum antiken Epos, hrsg. von Herwig Görgemanns/Ernst A. Schmidt, Meisenheim 1976, 129-172 
Serlorenzi, Mirella, Santa Lucia in Selcis. Lettura del palinsesto murario di un edificio a continuità di vita, in: Roma dall'antichità al medioevo, Bd. 2: Contesti tardoantichi e altomedievali, hrsg. von Lidia Paroli/Laura Venditelli, Rom 2004, 350-379

Sessa, Kristina, Christianity and the cubiculum: Spiritual Politics and Domestic Space in Late Antique Rome, in: JECS 15, 2007, 171-204

Shaw, Brent D., The Passion of Perpetua, in: PaP 139, 1993, 3-45

Shaw, Brent D., Body/Power/Identity: Passion of the Martyrs, in: JECS 4, 1996, 269312

Silvagni, Angelo, Intorno ad un gruppo di iscrizioni del IV e V secolo appartenenti alla basilica Vaticana, in: BCAR 57, 1929, 135-147

Silvagni, Angelo, Se il carme damasiano di S. Felice appartenga veramente a Nola, in: RivAC 12, 1935, 249-264

Simonetti, Manlio, Una nuova proposta su Ippolito, in: Augustinianum 36, 1996, 13 46

Sivan, Hagith, Anician Women, the Cento of Proba, and Aristocratic Conversion in the Fourth Century, in: VChr 47, 1993, 140-157

Smith, Rowland B. E., ,Restored Utility, Eternal City'. Patronal Imagery at Rome in the Fourth Century AD, in: ,Bread and Circuses'. Euergetism and Municipal Patronage in Roman Italy, hrsg. von Kathryn Lomas/Tim Cornell, London/New York 2003, 142-166

Solin, Heikki, Beiträge zur Kenntnis der griechischen Personennamen in Rom, Bd. 1, Helsinki 1971

Speck, Paul, Urbs, quam Deo donavimus. Konstantins des Großen Konzept für Konstantinopel, in: Boreas 18, 1995, 143-173

Speidel, Michael P., Maxentius and his Equites Singulares in the Battle at the Milvian Bridge, in: ClAnt 5, 1986, 253-262

Spera, Lucrezia, Interventi di papa Damaso nei santuari delle catacombe romane: il ruolo della committenza privata, in: Bessarione 11, 1994, 111-127

Spera, Lucrezia, Un nuovo centro di culto martiriale lungo la spelunca magna della catacomba di Pretestato, in: Domum tuam dilexi. Miscellanea in onore di Aldo Nestori, hrsg. von Federico Guidobaldi, Vatikanstadt 1998, 807-828

Spera, Lucrezia, Ad limina apostolorum. Santuari e pellegrini a Roma tra tarda antichità e l'alto medioevo, in: La geografia e lo spazio del sacro. L'esempio delle trasformazioni territoriali lungo il percorso della Visita alle Sette Chiese Privilegiate, Rom 1998, 1-104 (zit. Spera 1998 [a])

Spera, Lucrezia, Il paesaggio suburbano di Roma dall'antichità al medioevo. Il comprensorio tra le vie Latina e Ardeatina dalle Mura Aureliane al III miglio, Rom 1999 
Spera, Lucrezia, s. v. „S. Andreae basilica”, in: LTUR. Suburbium I, Rom 2001, 52-54

Spera, Lurezia, Il territorio della via Appia. Forme trasformative del paesaggio nei secoli della tarda Antichità, in: Suburbium. Il suburbio di Roma dalla crisi del sistema delle ville a Gregorio Magno, hrsg. von Philippe Pergola u. a., Rom 2003, 267-330

Spera, Lucrezia/Mineo, Sergio, Via Appia, Bd. 1. Da Roma a Bovillae, Rom 2004

Spera, Lucrezia/Smiraglia, Edwige, Il cosidetto battistero della catacomba di Priscilla a Roma: sistemazione monumentale e segni cultuali, in: L'edificio battesimale in Italia. Aspetti e problemi (Atti dell' VIII Congresso Nazionale di Archeologia Cristiana), Bordighera 2001, Bd. 2, 977-1002

Spicq, Ceslas, Notes de lexicographie néo-testamentaire. Supplément, Göttingen 1982

Srejović, Dragoslav/Vasić, Čedomir, Emperor Galerius’ Buildings in Romuliana (Gamzigrad, Eastern Serbia), in: AntTard 2, 1994, 123-141

Stanley, David J., New Discoveries at Santa Costanza, in: DOP 48, 1994, 257-261

Steinby, E. Margareta, s. v. „Ziegelstempel von Rom und Umgebung“, in: RE, suppl. 15, München 1978, 1489-1531

Steinby, E. Margareta, L’industria laterizia di Roma nel tardo impero, in: Società romana e impero tardoantico, Bd. 2: Roma. Politica, economia, paesaggio urbano, hrsg. von Andrea Giardina, Rom/Bari 1986, 99-164 u.438-446

Steinby, E. Margareta, La cronologia delle figlinae tardoantiche, in: Materiali e tecniche dell'edilizia paleocristiana a Roma, hrsg. von Margherita Cecchelli, Rom 2001, 127150

Stepper, Ruth, Der Kaiser als Priester: Schwerpunkte und Reichweite seines oberpontifikalen Handelns, in: Die Praxis der Herrscherverehrung in Rom und seinen Provinzen, hrsg. von Hubert Cancik/Konrad Hitzl, Tübingen 2003, 157-187

Sternberg, Thomas, Orientalium more secutus. Räume und Institutionen der Caritas des 5. bis 7. Jahrhunderts in Gallien, Münster 1991

Straub, Johannes A., Konstantins Verzicht auf den Gang zum Kapitol, in: Historia 4, $1955,297-313$

Straub, Jürgen, Personale und kollektive Identität. Zur Analyse eines theoretischen Begriffs, in: Identitäten. Erinnerung, Geschichte, Identität, Bd. 3, hrsg. von Aleida Assmann/Heidrun Friese, Frankfurt a. M. 1998, 73-104

Stuiber, Alfred, Die Diptychon-Formel für die nomina offerentium im römischen Meßkanon, in: EL 68, 1954, 128-146

Stuiber, Alfred, Refrigerium interim. Die Vorstellungen vom Zwischenzustand und die frühchristliche Grabkunst, Bonn 1957 
Stuiber, Alfred, Heidnische und christliche Gedächtniskalender, in: JbAC 3, 1960, 24 33

Stuiber, Alfred, s. v. „Eulogia“, in: RAC 6, Stuttgart 1966, 900-928

Stutz, Ulrich, Geschichte des kirchlichen Benefizialwesens von seinen Anfängen bis auf die Zeit Alexanders III., aus dem Nachlaß ergänzt und mit einem Vorwort versehen von Hans E. Feine, Aalen 21961 (Berlin 1895)

Styger, Paul, L'origine del cimitero di S. Callisto sull'Appia, in: RPARA 4, 1925-1926, $91-153$

Styger, Paul, Die römischen Katakomben. Archäologische Forschungen über den Ursprung und die Bedeutung der altchristlichen Grabstätten, Berlin 1933

Szidat, Joachim, Konstantin 312. Eine Wende in seiner religiösen Überzeugung oder die Möglichkeit, diese öffentlich erkennen zu lassen und aus ihr heraus Politik zu machen?, in: Gymnasium 92, 1985, 514-525

Talamo, Emilia, Raffigurazione numismatiche, in: Il „tempio di Romolo“ al foro romano, Rom 1981, 23-34

Taliaferro Boatwright, Mary, Hadrian and the City of Rome, Princeton 1987

Testini, Pasquale, L'oratorio scoperto al „,monte della giustizia“ presso la porta Viminale a Roma, in: RivAC 44, 1968, 219-260

Testini, Pasquale, Di alcune testimonianze relative a Ippolito, in: Ricerche su Ippolito, Rom 1977, 45-65

Testini, Pasquale, Vetera e nova su Ippolito, in: Nuove ricerche su Ippolito, Rom 1989, 7-22

Thomas, Yan, Corpus aut ossa aut cineres. La chose religieuse et le commerce, in: Micrologus 7, 1999, 73-112

Thümmel, Hans G., Die Wende Constantins und die Denkmäler, in: Die Konstantinische Wende, hrsg. von Ekkehard Mühlenberg, Gütersloh 1998, 144-185

Thümmel, Hans G., Die Memorien für Petrus und Paulus in Rom. Die archäologischen Denkmäler und die literarische Tradition, Berlin/New York 1999

Timpe, Dieter, Römische Geschichte und Heilsgeschichte, Berlin/New York 2001

Tolotti, Francesco, Memorie degli apostoli in catacumbas. Rilievo critico della memoria e della basilica apostolorum al III miglio della via Appia, Vatikanstadt 1953

Tolotti, Francesco, Il cimitero di Priscilla. Studio di topografia e architettura, Vatikanstadt 1970

Tolotti, Francesco, Ricercha dei luoghi venerati nella spelunca magna di Pretestato, in: RivAC 53, 1977, 7-102 
Tolotti, Francesco, Le basiliche cimiteriali con deambulatorio del suburbio romano: questione ancora aperta, in: $\mathrm{MDAI}(\mathrm{R})$ 89, 1982, 153-211

Tolotti, Francesco, Il problema dell'altare e della tomba del martire in alcune opere di papa Damaso, in: Studien zur spätantiken und byzantinischen Kunst. Friedrich Wilhelm Deichmann gewidmet, hrsg. in Verbindung mit Otto Feld/Urs Peschlow, Bd. 2, Bonn 1986, 51-71

Tolotti, Francesco, Il S. Sepolcro di Gerusalemme e le coeve basiliche di Roma, in: MDAI(R) 93, 1986, 471-512 (zit. Tolotti 1986 [a])

Tolotti, Francesco, I due mausolei rotondi esistiti sul lato meridionale del vecchio S. Pietro, in: RivAC 64, 1988, 287-315

Torelli, Mario, Culto imperiale e spazi urbani in età flavia. Dai rilievi Hartwig all'arco di Tito, in: L'urbs. Espace urbain et histoire (Ier siècle av. J.-C. - IIIe siècle ap. J.C.), Rom 1987, 563-582

Torelli, Mario, Le basiliche circiformi di Roma. Iconografia, funzione, simbolo, in: Felix temporis reparatio. Atti del convegno archeologico internazionale „Milano e l'impero romano“, Milano 1990, hrsg. von G. Sena Chiesa/A. Arslan, Mailand 1992, 203-217

Torelli, Mario, Le basiliche circiformi: Iconografia e forme mentali, in: Ecclesiae urbis. Atti del Congresso internazionale di studi sulle chiese di Roma (IV-X secolo), hrsg. von Federico Guidobaldi/Alessandra Guiglia Guidobaldi, Vatikanstadt 2002, Bd. 2, 1097-1108

Toynbee, Jocelyn M. C., Death and Burial in the Roman World, London 1971

Toynbee, Jocelyn M. C./Ward Perkins, John, The Shrine of St. Peter and the Vatican Excavations, London 1956

Treffort, Cécile, Du cimiterium christianorum au cimetière paroissial: évolution des espaces funéraires en Gaule du VIe au Xe siècle, in: Archéologie du cimitière chrétien, hrsg. von Henri Galinié/Elisabeth Zadora-Rio, Tours 1996, 55-63

Tripp, David, The Prayer of St Polykarp and the Development of Anaphoral Prayer, in: EL 104, 1990, 97-132

Trout, Dennis E., Paulinus of Nola. Life, Letters, and Poems, Berkeley u. a. 1999

Trout, Dennis E., Damasus and the Invention of Early Christian Rome, in: The Cultural Turn in Late Ancient Studies. Gender, Ascetism, and Historiography, hrsg. von Dale B. Martin/Patricia Cox Miller, Durham/London 2005, 298-315

Trout, Dennis E., Saints, Identity, and the City, in: A People's History of Christianity, Bd. 2: Late Ancient Christianity, hrsg. von Virginia Burrus, Minneapolis 2005, 165187

Turcan, Robert, Héliogabale précurseur de Constantin?, in: BAGB 1988, 38-52 
Ullmann, Walter, Leo I and the Theme of Papal Primacy, in: JThS, n. s. 11, 1960, 2551

Ullmann, Walter, Gelasius I. (492-496). Das Papsttum an der Wende der Spätantike zum Mittelalter, Stuttgart 1981

Urbain, August Ein Martyrologium der christlichen Gemeinde zu Rom am Anfang des V. Jahrhunderts. Quellenstudien zur Geschichte der römischen Märtyrer, Leipzig 1901

van Uytfanghe, Marc, L'origine, l'essor et les fonctions du culte des saints. Quelques repères pour un débat rouvert, in: Cassiodorus 2, 1996, 143-196

Vera, Domenico, La polemica contro l'abuso imperiale del trionfo: rapporti fra ideologia, economia e propaganda nel basso impero, in: RSA 10, 1980, 89-132

Vera, Domenico, Commento storico alle relationes di Quinto Aurelio Simmaco. Introduzione, commento, testo, traduzione, appendice sul libro X, 1-2, indici, Pisa 1981

Vera, Domenico, Osservazioni economiche sulla Vita Sylvestri del Liber Pontificalis, in: Consuetudinis amor. Fragments d'histoire romaine (IIe- VIe siècles) offerts à JeanPierre Callu, hrsg. von François Chausson/Étienne Wolff, Rom 2003, 419-430

Verrando, Giovanni N., Liberio-Felice. Osservazioni e rettifiche di carattere storicoagiografico, in: RSCI 35, 1981, 91-125

Verrando, Giovanni N., Note di topografia martiriale della via Aurelia, in: RivAC 57, 1981, 255-282 (zit. Verrando 1981 [a])

Verrando, Giovanni N., Osservazioni sulla collocazione cronologica degli apocrifi Atti di Pietro dello Pseudo-Lino, in: VetChr 20, 1983, 391-426

Verrando, Giovanni N., L'attività edilizia di papa Giulio I e la basilica al III miglio della via Aurelia ad Callistum, in: MEFRA 97,2, 1985, 1021-1061

Verrando, Giovanni N., Note sulle tradizioni agiografiche in Processo, Martiniano e Lucina, in: VetChr 24, 1987, 353-373

Verrando, Giovanni N., Analisi topografica degli antichi cimiteri sotterranei ubicati nei pressi delle due vie Aurelie, in: RivAC 63, 1987, 293-357 (zit. Verrando 1987 [a])

Verrando, Giovanni N., Il santuario di S. Felice sulla Via Portuense, in: MEFRA 100, 1988, 331-366

Verrando, Giobanni N., Passio SS. Xysti Laurentii et Yppoliti. La trasmissione manoscritta delle varie recensioni della cosiddetta Passio vetus, in: RecAug 25, 1991, 181 221

Verrando, Giovanni N., Reciproche influenze tra Roma e il Martirologio e Passionario Umbri, in: Atti del Convegno di Studio l'Umbria Meridionale fra Tardo-Anticho ed Altomedioevo, hrsg. von Gianfranco Binazzi, Perugia 1991, 99-110 (zit. Verrando $1991[\mathrm{a}])$ 
Verstrepen, Jean-Louis, Origines et instauration des quatre-temps à Rome, in: RBen 103, 1993, 339-365

Veyne, Paul, Brot und Spiele. Gesellschaftliche Macht und politische Herrschaft in der Antike, Frankfurt a. M. 1988 (Paris 1976)

Vidman, Ladislav, Inferiae und iustitium, in: Klio 53, 1971, 209-212

Vielliard, René, Les titres romains et les deux éditions du liber pontificalis, in: RivAC 5, 1928, 89-103

Vielliard, René, Recherches sur les origines de la Rome chrétienne, Rom 1941

Villa, Enrico, Il culto agli apostoli nell'Italia settentrionale alla fine del sec. IV, in: Ambrosius 33, 1957, 245-264

de Vinne, Michael J., The Advocacy of Empty Bellies: Episcopal Representation of the Poor in the Late Roman Empire, Diss. Stanford 1995

Vircillo Franklin, Carmela, Roman Hagiography and Roman Legendaries, in: SSAM 48: Roma nell'Alto Medioevo, Bd. 2, Spoleto 2001, 857-895

de Visscher, Fernand, Le droit des tombeaux romains, Mailand 1963

Vittinghoff, Friedrich, Epilog: Zur Entwicklung der städtischen Selbstverwaltung Einige kritische Anmerkungen, in: Stadt und Herrschaft. Römische Kaiserzeit und Hohes Mittelalter, hrsg. Von Friedrich Vittinghoff, München 1982, 107-146

Vogel, Cyrille, L'environnement cultuel du défunt durant la période paléochrétienne, in: La maladie et la mort du chrétien dans la liturgie, Conférences Saint-Serge, XXIe semaine d'études liturgiques, Paris, 1.-4. 7. 1974, Rom 1975, 381-413.

Vogel, Cyrille, Le liber pontificalis dans l'édition de Louis Duchesne. État de la question, in: Monseigneur Duchesne et son temps, Rom 1975, 99-127

Vogel, Cyrille, Une mutation cultuelle inexpliquée: le passage de l'eucharistie communautaire à la messe privée, in: RSR 54, 1980, 231-250

Vogel, Cyrille, La multiplication des messes solitaires au Moyen Age. Essai de statistique, in: RSR 55, 1981, 206-213

Vogt, Hermann J., Coetus sanctorum. Der Kirchenbegriff des Novatian und die Geschichte seiner Sonderkirche, Bonn 1968

Voelkl, Ludwig, Die Kirchenstiftungen des Kaisers Konstantin im Lichte des römischen Sakralrechts, Köln/Opladen 1964

Volp, Ulrich, Tod und Ritual in den christlichen Gemeinden der Antike, Leiden u. a. 2002

Volpe, Rita, Le ville del suburbio di Roma, in: Aurea Roma. Dalla città pagana alla città cristiana, hrsg. von Serena Ensoli/Eugenio La Rocca, Rom 2000, 161-167 
Vopel, Hermann, Die altchristlichen Goldgläser. Ein Beitrag zur altchristlichen Kunst- und Kulturgeschichte, Leipzig/Tübingen 1899

Wagner, Johannes, Altchristliche Eucharistiefeiern im kleinen Kreis, Diss. Bonn 1949 (Neuausgabe Trier 1993)

Wallace-Hadrill, Andrew, Princeps civilis. Between Citizen and King, in: JRS 72, 1982, $32-48$

Wallace-Hadrill, Andrew, The Social Structure of the Roman House, in: PBSR 56, 1988, 43-97

Walser, Gerold, Die Einsiedler Inschriftensammlung und der Pilgerführer durch Rom (Codex Einsidlensis 326). Faksimile, Umschrift, Übersetzung und Kommentar, Stuttgart 1987

Walter, Uwe, Die Botschaft des Mediums. Überlegungen zum Sinnpotential von Historiographie im Kontext der römischen Geschichtskultur zur Zeit der Republik, in: Institutionalität und Symbolisierung. Verstetigungen kultureller Ordnungsmuster in Vergangenheit und Gegenwart, hrsg. von Gert Melville, Köln u. a. 2001, 241-279

Walter, Uwe, Memoria und res publica. Zur Geschichtskultur im republikanischen Rom, Frankfurt a. M. 2004

Ward-Perkins, Bryan, From Classical Antiquity to the Middle Ages. Urban Public Building in Northern and Central Italy AD 300-850, Oxford 1984

Ward-Perkins, John B., Memoria, Martyr's Tomb and Martyr's Church, in: Akten des 7. Internationalen Kongresses für Christliche Archäologie, Trier 5.-11. 9. 1965, Bd. 1, Vatikanstadt 1969, 3-27

Warland, Rainer, Die spätantike Stadt als Leitbild und Lebensform, in: Die spätantike Stadt und ihre Christianisierung, hrsg. von Gunnar Brands/Hans-Georg Severin, Wiesbaden 2003, 291-298

Warland, Rainer, The Concept of Rome in Late Antiquity reflected in the Mosaics of the Triumphal Arch of S. Maria Maggiore in Rome, in: Rome AD 300-800. Power and Symbol - Image and Reality (AAAH 17), Rom 2003, 127-141 (zit. Warland $2003[\mathrm{a}])$

Waurick, Götz, Untersuchungen zur Lage der römischen Kaisergräber in der Zeit von Augustus bis Constantin, in: JRGZ 20, 1973, 107-146

Weber, Gregor, Kaiser, Träume und Visionen in Prinzipat und Spätantike, Stuttgart 2000

Weber, Max, Die „Objektivität“ sozialwissenschaftlicher und sozialpolitischer Erkenntnis, in: ders., Gesammelte Aufsätze zur Wissenschaftslehre, hrsg. von Johannes Winckelmann, Tübingen ${ }^{71988, ~ 146-214 ~(u r s p r . ~ e r s c h i e n e n ~ i n: ~ A r c h i v ~ f u ̈ r ~}$ Sozialwissenschaft und Sozialpolitik 19, 1904, 22-87) 
Weber, Wolfgang E. J., Das „kulturelle Gedächtnis“. Bemerkungen zur Wahrnehmung und Aneignung einer kulturhistorischen Konzeption, in: Erinnern Gedenken - historisches Lernen. Symposium zum 65. Geburtstag von Karl Filser, hrsg. von Wolfgang Hasberg, München 2003, 15-37

Weiland, Albrecht Conposuit tumulum sanctorum limina adornans. Die Ausgestaltung des Grabes der Hl. Felix und Adauctus durch Papst Damasus in der Commodillakatakombe in Rom, in: Historiam pictura refert. Miscellanea in onore di Alejandro Recio Veganzones, Vatikanstadt 1994, 625-645

Welzer, Harald, Das kommunikative Gedächtnis. Eine Theorie der Erinnerung, München 2002

Wesch-Klein, Gabriele, Funus publicum. Eine Studie zur öffentlichen Beisetzung und Gewährung von Ehrengräbern in Rom und den Westprovinzen, Stuttgart 1993

Wesch-Klein, Gabriele, Damasus I., der Vater der päpstlichen Epigraphik, in: Quellen, Kritik, Interpretation. Festgabe zum 60. Geburtstag von Hubert Mordeck, hrsg. von Thomas M. Buck, Frankfurt a. M. 1999, 1-30

White, L. Michael, The Social Origins of Christian Architecture, Bd. 2: Texts and Monuments for the Christian Domus Ecclesiae in Its Environment, Valley Forge 1997

Whitehead, Philip B., The Church of S. Anastasia in Rome, in: AJA n. s. 31, 1927, 405-420

Wickert, Lothar, s. v. „Princeps (civitatis)“, in: RE 22, 2, Stuttgart 1954, 1998-2296

Wickham, Chris, Framing the Early Middle Ages. Europe and the Mediterranean, 400 - 800, Oxford 2005

Wieland, Franz, Altar und Altargrab der christlichen Kirchen im 4. Jahrhundert. Neue Studien über den Altar der altchristlichen Liturgie, Leipzig 1912

Wiemer, Hans-Ulrich, Libanios und Zosimos über den Rom-Besuch Konstantins I. im Jahre 326, in: Historia 43, 1994, 469-494

Wiemer, Hans-Ulrich, Staatlichkeit und politisches Handeln in der römischen Kaiserzeit - Einleitende Bemerkungen, in: Staatlichkeit und politisches Handeln in der römischen Kaiserzeit, hrsg. von Hans-Ulrich Wiemer, Berlin/New York 2006, $1-39$

Wilpert, Joseph, Le pitture della confessio sotto la basilica dei SS. Giovanni e Paolo, in: Scritti in onore die Bartolomeo Nogara, Vatikanstadt 1937, 517-522

Windfeld-Hansen, Hemming, Les couloirs annulaires dans l'architecture funéraire antique, in: AAAH 2, 1965, 35-64

Winterling, Aloys, Aula Caesaris. Studien zur Institutionalisierung des römischen Kaiserhofes in der Zeit von Augustus bis Commodus (31 v. Chr. - 192 n. Chr.), München 1999 
Winterling, Aloys, Cour sans „État“. L'aula Caesaris aux Ier et IIe siècles de notre ère, in: Rome, les Césars et la Ville au deux premiers siècles de notre ère, hrsg. von Nicole Belayche, Rennes 2001, 185-206 (= ders., Hof ohne „Staat“. Die aula Caesaris im 1. und 2. Jahrhundert n. Chr., in: Zwischen „Haus“ und „Staat“. Antike Höfe im Vergleich, hrsg. von Aloys Winterling, München 1997, 91-112)

Winterling, Aloys, „Öffentlich“ und „privat“ im kaiserzeitlichen Rom, in: Gegenwärtige Antike - antike Gegenwarten. Kolloquium zum 60. Geburtstag von Rolf Rilinger, hrsg. von Tassilo Schmitt u. a., München 2005, 223-245

Wirbelauer, Eckhard, Zwei Päpste in Rom. Der Konflikt zwischen Laurentius und Symmachus (498-514). Studien und Texte, München 1993

Wirbelauer, Eckhard, Die Nachfolgerbestimmung im römischen Bistum (3.-6. Jh.). Doppelwahlen und Absetzungen in ihrer herrschaftssoziologischen Bedeutung, in: Klio 76, 1994, 388-437

Wissowa, Georg, Religion und Kultus der Römer (HdA, Bd. 5, 4), München 21912

Witschel, Christian, Rom und die Städte Italiens in Spätantike und Frühmittelalter, in: BJ 201, 2001, 113-162

Wlosok, Antonie, Märtyrerakten und Passionen, in: Handbuch der lateinischen Literatur der Antike, hrsg. von Reinhart Herzog/Peter L. Schmidt, Bd. 4: Die Literatur des Umbruchs. Von der römischen zur christlichen Literatur, 117-284 n. Chr., hrsg. von Klaus Sallmann, München 1997, 419-432

Wojtowytsch, Myron, Papsttum und Konzile von den Anfängen bis zu Leo I. (440461). Studien zur Entstehung der Überordnung des Papstes über Konzile, Stuttgart 1981

Wrede, Henning, Consecratio in formam deorum. Vergöttlichte Privatpersonen in der römischen Kaiserzeit, Mainz 1981

Wrede, Henning, Der genius populi Romani und das Fünfsäulendenkmal der Tetrarchen auf dem Forum Romanum, in: BJ 181, 1981, 111-142 (zit. Wrede 1981 [a])

Wrede, Henning, Bildnisse epikureischer Philosophen, in: MDAI(A) 97, 1982, 235245

Zanker, Paul, Das Trajansforum in Rom, in: AA 1970, 499-544

Zeiller, Jacques, Les églises ariennes de Rome à l'époque de la domination gothique, in: MEFR 24, 1904, 17-33

Zimmermann, Norbert, Werkstattgruppen römischer Katakombenmalerei, Münster 2002 



\section{Register}

Die Verweise beziehen sich ausschließlich auf die Seiten, Anmerkungen werden nicht eigens als solche gekennzeichnet

\section{Antike Namen}

Achilleus v. Spoleto $247 \mathrm{f}$.

Acilius Severus 142

Agapetus, röm. Diakon 297f., 472

Aginatius 229

Agnes, röm. Heilige 107, 156, 173, 301, 449, 467

Agricola, Heiliger aus Bologna 361

Alexander Severus, röm. Kaiser 175, 192, 196, 218

Ambrosius v. Mailand 53, 236, 280, 286, 297f., 315f., 321, 341, 345, 356, 360-363, 370, 377f., 386, 401, 498, 529

Anastasia, Schwester Konstantins 161, 376

Anastasia, Heilige aus Sirmium 349, 351-353, 359, 363, 372-375

Anastasius I., Bf. von Rom 279

Anastasius II., Bf. von Rom 223, 481

Andreas, Apostel 314f., 361f., 414, 427

Anictet, Bf. von Rom 217

Anteros, Bf. von Rom 267

Antoninus Pius, röm. Kaiser 185, 189

Arkadios, röm. Kaiser 161

Athanasius v. Alexandrien 237, 320, 447, 458

Augustinus v. Hippo 245, 279f., 313

Augustus, röm. Kaiser 127, 182, 186, 188, 189, 203

Bonifatius I., Bf. von Rom 223, 242-248, 250, 350, 483, 501

Bonifatius IV., Bf. von Rom 425, 446

Caecilianus v. Karthago 277, 377

Caelestinus, Bf. von Rom 222, 253, 286, 354, 411, 483

L. und C. Caesar 58, 183, 202, 334

Caesarius v. Arles $532 f$.

Caligula, röm. Kaiser 187

Caracalla, röm. Kaiser 185, 205 
Carinus, röm. Kaiser 368f.

Carus, röm. Kaiser 368

Clodius Celsinus Adelphius 374

Chrysogonus, Heiliger aus Aquileia 349-351, 359, 362, 367, 371-375

Claudianus, donatist. Bf. von Rom 288

Claudius, röm. Kaiser 182

Clemens, Bf. von Rom 267, 342f., 350

Q. Cominius Abascantus 513f., 525

Constans, röm. Kaiser 100, 447

Constantina 106f., 156, 173, 450f., 465-467

Constantius I. Chlorus, röm. Kaiser 93, 100, 128, 196, 198

Constantius II., röm. Kaiser 17, 100, 110f., 119, 151, 174, 211, 222, 224, 236, 249, 316, 391, 447f., 465

Cornelius, Bf. von Rom 39, 253, 259, 350

Crispus 133f., 146

Cyprian, Bf. von Karthago 63, 69f., 278, 280, 350, 520

Damasus, Bf. von Rom 31, 84, 101f., 162, 164, 172, 209, 220, 224-231, 234, 236-242, 260, 270-272-276, 289-324, 327-329, 330, 332, 334, 341, 352, 375, 377, 451, 458f., 466, 471, 488f., $497 \mathrm{f}$.

Decentius v. Gubbio 333, 339, 412

Decius, röm. Kaiser 34f.

Amnia Demetrias 370, 399

Diocletian, röm. Kaiser 82, 87f., 115, 123

Domitian, röm. Kaiser 187f., 203

Drusilla 203

Drusus minor 183, 202

Elagabal, röm. Kaiser 140, 145, 175

Eugenius, röm. Kaiser 397

Eulalius, Bf. von Rom 223, 242-250, 478, 483, 501

Eusebius, Bf. von Rom 294, 297

Eutychian, Bf. von Rom 39

Fabianus, Bf. von Rom 39, 153, 253, 267, 272

Faltonia Betitia Proba 317f., 374

Faltonius Pinianus 225

Fausta, röm. Kaiserin 98, 100, 133, 146, 158

Faustina, röm. Kaiserin 184

Felicissimus, röm. Diakon 297f.

Felicitas, röm. Heilige 435, 483

Felix II., Bf. von Rom 33, 222-224, 234-236, 238f., 407, 447-455, 457-473, 501

Felix III., Bf. von Rom 470, 472, 481

Felix IV., Bf. von Rom 446

Felix v. Nola 300, 363, 471 
Flavius Ricimer 251

Flavius Valila 251, 335, 399

Galerius, röm. Kaiser 99, 196

Galla Placidia 244, 249

Gallienus, röm. Kaiser 34, 75, 99, 175, 196

Gaudentius v. Brescia 315f., 341, 361, 378

Gelasius I., Bf. von Rom 267, 373, 420, 422, 474, 481

Germanicus 183, 202

Gervasius und Protasius 297f., 339, 341f., 357, 359-362 , 366

Geta, röm. Kaiser 185, 205

Gildo 398

Gordian III., röm. Kaiser 185

Gorgonia 382

Gorgonius, röm. Heiliger 172, 346

Gratian, röm. Kaiser 229, 386

Gregor I., Bf. von Rom 35f., 251, 370, 416, 425, 427, 435

Gregor II., Bf. von Rom 408

Hadrian, röm. Kaiser 91, 182, 184f., 189, 203

Helena, Mutter Konstantins 105, 155, 158, 170, 176, $178 f$.

Helena, Gattin Julians 107, 156

Heracleida v. Oxyrrhynchos 274

Hermes, röm. Heiliger 301, 307

Hieronymus 83, 313, 316, 383f., 395f., 422, 460, 531

Hilarus, Bf. von Rom 249, 331, 397, 408, 413, 471, 481

Hippolytos, röm. Presbyter 39, 72, 108f., 216-219, 254, 272-275, 294, 301, 350

Honorius, röm. Kaiser 161, 244, 247f., 392, 404

Honorius I., Bf. von Rom 36f., 333, 335

Ignatius v. Antiochia 216

Innozenz I., Bf. von Rom 167, 222, 253, 332f., 339, 341, 349, 362, 412, 420, 483

Johannes III., Bf. von Rom 486

Iovian, röm. Kaiser 182

Iovinian 221

Julian, röm. Kaiser 107, 146, 185, 194, 381, 406

Iulius, Bf. von Rom 167, 233, 237, 279, 280, 318, 334, 447, 452f., 455, 464-468, 472

Iuvenal v. Jerusalem 468

Kallixt I., Bf. von Rom 39f., 72, 217, 272, 324, 453

Konstantin I., röm. Kaiser 29, 81-86, 95-99, 104, 108-114, 119, 122-153, 161-163, 169-171, 174-181, 190, 199, 207-214, 253, 328, 330, 333, 488, 492-495, 503

Laurentius, röm. Diakon 108f., 163, 255, 275, 341, 350, 359, 383, 472

Laurentius, Bf. von Rom 33, 37, 223, 276, 405, 425, 427, 468-470, 473-476, 479f., 501 
Leo I., Bf. von Rom 254, 291, 311, 315f., 352, 356, 357, 370, 397, 399, 420, 423, $425,460,471,479,481$

Leo II., Bf. von Rom 36

Leo IV., Bf. von Rom 431

Liberius, Bf. von Rom 33, 163, 222-224, 230f., 233-236, 238f., 334, 407, 447-453, 457468,501

Licinius, röm. Kaiser 74, 99, 104, 135, 146, 158

Lucilla, Matrone aus Karthago 377

Lucina, röm. Matrone 225, 259f., 263-265, 266, 269, 271, 435

Lucius Verus, röm. Kaiser 117, 182

Macrina 382

Maiorinus v. Karthago 277

Makedonios v. Konstantinopel 253

Marcella 396

Marcellinus, Bf. von Rom 282, 468

Marcellus, Bf. von Rom 225, 282, 294

Marcus Aurelius, röm. Kaiser 189

Marcus, Bf. von Rom 106, 154, 160, 333f., 464f.

Maria, röm. Kaiserin 160

Martin v. Tours 363

Märtyrer von Lyon $70 f$.

Maxentius, röm. Kaiser 82, 84f., 87, 90, 95-101, 111, 122-132, 141, 152, 190, 195, 199, 213, 494

Maximian, röm. Kaiser 87f., 93

Maximus v. Turin 315f.

Melania d. Ä. 364, 371, 376, 499

Melania d. J. 225, 355, 383, 396, 420

Miltiades, Bf. von Rom 99, 104, 277, 282

Nazarius, Heiliger aus Mailand 361

Nicomachus Flavianus 148

Novatianus, Bf. von Rom 63, 219, 253-255

Q. Clodius Hermogenianus Olybrius 229

Optatus v. Karthago 50

Optatus v. Mileve 277-280, 282-286

Orosius 313f.

Ossius v. Corduba 135, 140

Ovinius Gallicanus 143

Palladius v. Retiaria $321 \mathrm{f}$.

Pammachius 309, 335, 355, 365f., 530f.

Pancratius, röm. Heiliger 470

Parmenianus 282

Paulina, Gattin des Pammachius 530f. 
Paulinus von Nola 244, 311, 314, 316, 361, 363-365, 371, 376, 395f., 401, 499, $530 \mathrm{f}$.

Paulus 29, 41-43, 45, 63, 66, 75, 255f., 259, 270, 280, 291, 308, 317-322, 325, 341, 359, $362,442,490,496,501,522$

Paul I., Bf. von Rom 37, 429

Pelagius 221

Pelagius II., Bf. von Rom 36, 108

Peregrinus Proteus 74

Perpetua, kathag. Märtyrerin 50f., 68, 73

Petros Patrikios 149f.

Petrus 29, 38, 41-43, 45, 63, 66, 75, 255-257, 259, 270, 276, 278-281, 291, 308, 317$322,325,341,359,362,442,451,466-468,470,476-478,490,496,501$

Petrus v. Altinum 475, 478

Petrus und Marcellinus, röm. Heilige 163, 172f., 302, 348, 493

Philocalus 303, 310

Polykrates v. Ephesos 308

Pontianus, Bf. von Rom 39, 72, $272 \mathrm{f}$.

Vettius Agorius Praetextatus 227, 375

Faltonia Betitia Proba 317f., 369, 374

Anicia Faltonia Proba 369f., 399

Sex. Claudius Petronius Probus 336, 369-371

Processus und Martinianus, röm. Heilige 442, 470

Prosper v. Aquitanien 460

Prudentius 84, 313, 316, 319

Quattro Coronati 345-348, 359, 363

Quirinus v. Siscia 359

Romulus und Remus 92, 95, 291, 309, 311, 315

Romulus, Sohn d. Maxentius 91, 93, $194 \mathrm{f}$.

Rusticola, novatian. Bf. v. Rom 286

Sabina, röm. Kaiserin 184

Sabina, Heilige 355, 359, 363

Saturninus, röm. Heiliger 307

Saturus, karthag. Märtyrer 50f., 67, 73

Sebastian, röm. Märtyrer (s. auch passio Sebastiani) 262f., 269

Septimius Severus, röm. Kaiser 175, 203

Silanus, röm. Heiliger 257, 483

Silvester I., Bf. von Rom 280f., 332-334, 468

Simplicius, Bf. von Rom 251, 399, 411, 422, 424, 471, 481

Siricius, Bf. von Rom 102, 278, 286, 324, 395f., 402, 459

Sixtus II., Bf. von Rom 109, 218, 255, 297, 350, 359, 471

Sixtus III., Bf. von Rom 39, 108f., 231, 233, 241, 330, 347, 357, 358, 397, 411, 468, 471

Sopatros $147 \mathrm{f}$.

Soter, Bf. von Rom 216 
Stephan II., Bf. von Rom 429

Sulpicius Severus 363f., 371, 376, 499

Aurelius Anicius Symmachus 243-248, 392

Symmachus, Bf. von Rom 33, 37, 223, 260, 276, 405, 413, 424f., 468-470, 473-481, 501

Tertullian 69

Theoderich 309, 405, 474-476, 478

Theodor v. Ikonium 301

Theodosius I., röm. Kaiser 129f., 148, 287

Timotheus, Apostel 314

Titus, röm. Kaiser $187 f$.

Trajan, röm. Kaiser 182, 184, $188 f$.

Urbanus, Bf. von Rom 39f.

Ursinus, Bf. von Rom 223-231, 236-242, 274, $458 f$.

Valens, röm. Kaiser 229

Valentinian I., röm. Kaiser 113, 229

Valentinian III., röm. Kaiser 108, 358, 404

Valerian, röm. Kaiser 34f., 218

Valerius Pinianus 225, 383, 396

Valerius Poplicola 93

Vespasian, röm. Kaiser 187f.

Vestina 341, 365f., 399

Victor I., Bf. von Rom 39f., 216, 218, 308

Victor v. Garba 284

Victricius v. Rouen 341, 361, 378

Vitalis, Heiliger aus Bologna 342, 361

Zephyrinus, Bf. von Rom 39f., 217, 272

Zosimos, Bf. von Rom 223, 242, 342

\section{Orte}

Antium 247

Aquileia 349-351, 353, 361, 366-368, 371, 375

Arles (s. auch Synode v. Arles) 431, 532

Bologna 342, 361

Dura-Europos 331 
Florenz 361

Fundi 342, 361, 364

Gallien 341, 356, 361f., 401, 416f., 534

Hippo 245

Illyrikum 353, 354f., 359, 362f., 371, 375

Jerusalem 364, 383

Karthago 50, 68, 86, 279, 307, 350, 520

Konstantinopel 1, 32, 82, 134, 143, 145-148, 150f., 211f., 214, 252, 253, 314, 320, 352 , 391f., 402, 409f., 427, 473, 485, 500

- Apostelkirche 153, 161, 200, 211f., 362

Mailand 82, 315, 357, 359-362

- basilica Ambrosiana 298, 361

- basilica apostolorum 341, $361 \mathrm{f}$.

Misenum 513f.

Nikomedien 82, 99

Nola 300, 361, 395, 471

Oberitalien 341, 345, 353, 360f., 401

Ostia 336, 357

Pannonien 347f., 359

Parentium/Porec 345

Porto 274, 335

Primuliacum 364

Ravenna 242, 247, 342, 345, 355, 361

Rom:

- Alexandercoemeterium 429

- Augustusmausoleum 183f., 187, 192

- basilica apostolorum (s. S. Sebastiano)

- basilica Iulii 132, 225, 231, 233, 235, 240, 243, 411

- basilica Iulii an der via Aurelia 453f., 464

- basilica Iulii an der via Portuensis 453-455, 464

- basilica Liberii (s. auch S. Maria Maggiore) 226-228, 230f., 233, 235, 240f., 288, 449

- basilica Marci 101, 111, 154, 160

- basilica Nerei et Acbillei 102

- basilica Sicinini (s. basilica Liberii) 
- Basilika bei Tor de' Schiavi 97, 101-103, 154, 158f., 163, 166

- Mausoleum 102f., 158f., 165f., 192-194

- Bassillacoemeterium 48, 102

- Calepodiuskatakombe 453f.

- civitas Leoniana 426, 431

- Commodillacoemeterium 48, $304 \mathrm{f}$.

- coemeterium Balbinae 359

- coemeterium Iordanorum 344

- coemeterium maius 48, 467, 477

- coemeterium Marci et Marcelliani 102

- coemeterium Ostrianum (= coemeterium maius) 451, $465 f$.

- Colosseum 404, 410

- Solstatue 91

- Diocletiansthermen 88, 112, 251, 343

- Domitillakatakombe 102, 359

- domus Faustae 104

- ecclesia Theodorae 243

- Esquilin 231, 251, 273, 287, 449

- Felicitascoemeterium 247, 483

- forum pacis 94

- forum Romanum 87f., 95, 404, 409

- Fünfsäulendenkmal 87-89, 92, 124, 131

- fundus Laurentum 175-177

- Generosakatakombe 102, 454, 456

- Hadriansmausoleum 183f., 192, 313, 412

- Hippolytuskatakombe 108f., 254, 272

- Hippolytusoratorium 273f., 393

- Kallixtcoemeterium 34, 38-40, 49, 154, 218-220, 359, 430

- Kapitol 83, 86, 133-145, 186, 214 - in Märtyrerpassionen 144, 444

- Konstantinsbogen 91, 124-127, 130f., 136f., 139, 141

- Marstempel an der via Appia 436

- Maxentiusbasilika 85, 90, 92, 106, 112, 122-124, 132

- „Maxentiusforum“ 91, 124

- Maxentiusvilla 85, 97-99, 190f., $194 \mathrm{f}$.

- Mausoleum 94, 98, 159, 165, 190-195, 204, 206

- Maximuscoemeterium 483

- Novatianuskatakombe 254f., 272

- Novellacoemeterium 451, 465

- Oratorium am Monte della Giustizia 251, 394

- Ospedale di S. Giovanni in Laterano 393

- Palatin 190

- Pamphiluskatakombe 48

- Pantheon 193, 219, 446

- Pontianuskatakombe 454, 456, 484

- Praetextatuskatakombe 39, 304, 486 
- Priscillakatakombe 48f., 452, 484

- S. Agata dei Goti 251

- S. Agata in fundo Lardario 477

- S. Agnese 36, 97, 100, 106f., 118, 162f., 173f., 177f., 228, 397, 450-452, 465-467, 483

- Baptisterium 156, 452

- S. Anastasia/titulus Anastasiae 351-353, 372-375, 401

- S. Andrea in Catabarbara 251, 335, 399

- SS. Apostoli (s. auch basilica Iulii) 232f., 411

- S. Balbina/titulus s. Balbinae 333, 359, 400, 486

- S. Cecilia/titulus Caeciliae 334, 340, $353 \mathrm{f}$.

- S. Clemente/titulus Clementis 334, 340, $342 \mathrm{f}$.

- SS. Cosma e Damiano 446

- S. Costanza 107, 156f., 173, 177, 193

- S. Crisogono/titulus Chrysogoni 333f., 349-351, 368f., 372-375, 401

- S. Croce 97, 104f., 111, 171, 176f., 493

- S. Giovanni in Laterano 97, 103-105, 111f., 171, 176f., 209, 226, 230-233, 240, 243-246, 247-249, 333, 393, 408, 411, 430, 478, 493

- Baptisterium 103f., 249, 413,430, 477, 501

- SS. Giovanni e Paolo/titulus ss. Iohannis et Pauli 331, 334, 355-357, 362, 379, 397f., $401 f$.

- Oratorium 380-382, 397f., 402, 500

- S. Lorenzo f.l.m. 1, 36, 97, 100, 108f., 117f., 154, 158, 162f., 174, 232, 255, 358, 383, 397, 411-413, 424, 502

- S. Lorenzo in Damaso/titulus Damasi 271, 331, 334, 341, 358, 359

- S. Lorenzo in Formonso 358

- S. Lorenzo in Lucina/titulus Lucinae 225, 233-235, 271, 331, 358, 359

- S. Lucia in Selcis 335

- S. Marcello al Corso/titulus Marcelli 225, 243

- S. Marco/titulus Marci 132, 334

- S. Maria ad martyres 446

- S. Maria Maggiore 108, 232f., 411

- S. Matteo in Merulana/titulus s. Matthaei 331, 338, 358

- SS. Nereo ed Achilleo/titulus ss. Nerei et Achillei 359, 486

- S. Pancrazio 425, 454, 477

- S. Paolo f.l.m. 1, 36, 232, 249, 313f., 326f., 411-413, 424, 444, 479f., 482, 502

- konstantinische Basilika 97, 110, 174

- Basilika des späten 4. Jh. 174, 412

- S. Pietro in Vaticano 1, 36, 84, 232, 243, 250f., 257, 313f., 326f., 370, 397, 411-413, 424-426, 428, 430, 444, 451, 465, 475, 478, 480, 482, 498, 502, 530

- aedicula 38,162

- konstantinische Basilika 97, 109f., 117f., 162, 174

- kaiserl. Mausoleum/S. Petronilla 160f., 414, 428f.

- Baptisterium 157, 413f., 426, 430, 465, 477, 501

- S. Andrea 161, 414, 418, 424, 426, 427-430, 486

- episcopia 426 
- S. Pietro in Vincoli/titulus apostolorum 333, 341, 357, 359, 443

- SS. Pietro e Marcellino 97, 100f., 105f., 111, 118, 154, 162f., 165f., 169-179, 207, 210, 493

- Katakombe 55, 162f., 173, 304, 346-348

- Helenamausoleum 155f., 165f., 169-173, 178f., 207-211, 493

- S. Pudenziana/titulus Pudentis 338

- SS. Quattro Coronati/titulus ss. Quattuor Coronatorum 333, 338, 345-348, 400

- S. Sabina/titulus s. Sabinae 334, 338, 354f.

- S. Sebastiano 97-101, 117f., 154f., 157f., 162f., 177f., 255, 265, 270, 308, 359, 397

- Triklia 29, 40-42, 66, 75, 162f., 178, 255-257, 490, 503, 536

- S. Severino in Merulana 251

- S. Sisto Vecchio/titulus s. Sixti 359, 486

- S. Stefano Rotondo 232

- S. Stefano in via Latina 370, 399

- S. Susanna/titulus s. Susannae 334, 343-345

- S. Vitale/ titulus Vestinae 332, 338-340, 362, 399, 401

- Sessorium 85, 104, 175-177, 179, 190, 493

- Suburbium 29f., 82, 86, 96, 103, 111, 114, 116, 152, 175, 212, 213, 229f., 232, 242, 244, 274, 285, 288, 293, 304-307, 313, 326, 328, 330, 337, 396f., 400, 405f., 425, 430, 431, 432, 482, 485, 488, 496, 498, 500, $501 \mathrm{f}$.

- „Tempel des Romulus“ 90, 93f., 123f., 195

- templum gentis Flaviae $187 \mathrm{f}$.

- titulus Aemilianae (s. SS. Quattro Coronati)

- titulus Aequitii (s. titulus s. Silvestri)

- titulus Byzantis (s. SS. Giovanni e Paolo)

- titulus Gaii (s. S. Susanna)

- titulus Iulii 225f., 233-235, 394, 452f.

- titulus ss. Marcellini et Petri 360, 486

- titulus Nicomedis (s. S. Matteo in Merulana)

- titulus Pammachii (s. SS. Giovanni e Paolo)

- titulus s. Silvestri 332, 393

- titulus Vestinae (s. S. Vitale)

- Trajansforum 225, 336, 393

- Trajanssäule $188 \mathrm{f}$.

- Trastevere 225, 234f., 367f., 449

- Venus und Roma-Tempel 90f., 94f., 122-124

- Xenodocbium Aniciorum 335, 370

Romuliana 196

San Canzian d'Isonzo 350, 366

Serdika (s. auch Konzil v. Serdika) 149 f.

Sirmium 347, 349, 351-353, 373, 375

Split (Diocletiansmausoleum) 194, 196, 200 
Thessaloniki 196

Trier 82, 196

Vindena 355

\section{Sachen}

Akklamationen 244-246, 325, 459

Almosentätigkeit 423, 514, 528-530, 532

Altar 169f., 178, 207-209, 360, 364, 413f., 415-417, 430, 486, 503, 533

amicitia 363-365, 376, 378, 387, 401f., 499f.

Apostelreliquien 345, 361f., 364

apostolische Tradition 31, 240f., 250, 278-280, 282, 325, 477, 479f., 482, 501, 504

Arianer 251-252

Arme, Armut (s. auch pauper Christi) 39, 51, 514, 517-520, 525-527, 528-533, $535 f$.

asketische Gemeinschaften 370, 383, 391-393, 396, 500, 532f., 534

Baptisterien 84, 103, 156f., 249, 331, 410, 413f., 426, 430f., 451f., 466, 477, 484, 501

Basilikalklöster 397, 402, 417, 425, 500

Bestattungen im städtischen Raum 406f.

bischöfliche Sukzession 39f., 217f., 240-242, 278-280, 282, 325, 464f., 473, 479f., 501

Bischofskirchen in Rom 230, 232-234, 241, 243, 246f., 250f., 325, 332f., 339, 408, 435, 502

Bischofsweihe 231, 244-246

caritas (s. auch Almosentätigkeit) 54f., 66, 68, 78, 491, 515, 517-521, 535

cathedra Petri 277-286, 291, 327, 443, 496

Chronograph von 354/Philocaluskalender 25, 257, 290

civilitas principis 85, 95, 121, 130f., 409

coemeteria 34, 153f., 167f., 218-220, 228, 230, 241, 253, 272, 333, 339f., 359, 430, 483, 486, 495f., 503

Coemeterialbasiliken 86, 97, 101, 105-109, 111, 117f., 153-181, 199, 212, 330, 396, 412, 493

collegia (s. Vereine)

confessio (Altarconfessio) 413f., 429-431, 486

Confessoren 34f., 63-65, 70, 144, 207, 491

conversio Constantini 81, 135, 137, 143, 146-148, 151

Damasusepigramme 289f., 294-310, 489

decische Verfolgung 34f., 50, 63, 74

decretum Gelasianum 267f., 373, 435

Demographie 215, 407, 489, 502

Denkmal 7, 20, 21f., 290, 293, 298, 302 
depositio episcoporum 25, 40, 290

depositio martyrum 25, 40, 42, 172, 255-257, 290

Dioskuren 291, 309, 311, 317f., 327, 329

Divinisierung 179, 182, 185, 197, 200, 495, 503

divus 181-190, 193, 196, 200, 203, 213, 494

domus 27, 31f., 120f., 221, 234, 286f., 330-337, 378, 385-390, 400, 402, 405, 499f., 504 - in Märtyrerlegenden 263, 372, 437f., 455, 484

Donatisten 17, 104, 135, 221, 276-289, 326, 496

Erinnerungsforschung

- kulturwissenschaftliche 3-10, 79

- mediävistische 4, 12-15

Erinnerungsort/ lieu de mémoire 5, 19-23

Eucharistie 52, 72, 167, 170, 180, 397, 415, 419f. , 493, 503, 507, 533

Euergetismus 22, 62, 66, 78, 204f., 330, 423, 490, 510-521, 525-527, 529, $530 \mathrm{f}$.

fermentum 167, 217, 333, 339, 401

Frieden (s. pax)

Gabentausch 4, 13f., 16, 22f., 33f., 423, 487, 491, 507, 508-512, 515, 520f., 524-530, $532-537$

Gebetsverbrüderungen 13, 535

Gefängnis 50f., 63, 68-75, 491

- in Märtyrerlegenden 433, 437, 439-441

Gemeinschaft der Lebenden und Toten 43-55, 60, 492, 500, 506, 527, 535f., 537

gesta Eusebii presbyteri 449, 464-466, 469

gesta inter Liberium et Felicem episcopos 224, 238, $448 \mathrm{f}$.

gesta Liberii 443, 450f., 464-470, 473, 476f., 481, 484

gesta martyrum Romanorum 21, 27, 32f., 37, 258-269, 276, 283, 326, 432-447, 489, 503

Goldgläser 47f.

Graffiti 29, 38, 41-45, 49, 73-75, 77, 79, 255, 290, 536

Häresiebegriff 220-222

hereditas Petri 286, $323 \mathrm{f}$.

Heroenkult 189, 200-206

Heroon 200, 203f.

Hirte des Hermas 525f., 528, 530, 532, 535

bumilitas/Verdemütigung 64, 69-71, 75f., 79, 409, 492, 506

Identität 2f., 6f., 11f., 20f., 26f., 85f., 113f., 143-145, 151-153, 179, 212-214, 215-221, 223, 241f., 245-247, 251, 252, 254f., 264-266, 273-275, 284-287, 290f., 293f., 302f., 307, 309, 311-317, 324-329, 377, 402, 410, 432, 445f., 477, 485, 487, 488-490, 493f., 496f., 498, 499f., 503f., 510-512, 515f., 518, 520

imagines $185,386 \mathrm{f}$.

Indexkataloge 459-461, 470 
Interzession/fürbittendes Gebet 13f., 16, 26, 44, 54, 61, 63-65, 76-79, 299, 491f., 503, 504f., 521-524, 526f., 528, 530-536

Jenseitsvorstellungen 56f., 59f., 181

Jovinianer 221

Kaiserkult 86, 94, 171, 174, 178-180, 182f., 193f., 200-212, 213, 488, $494 f$.

Kaisertempel 183-190

Kalender 25, 172, 343, 456, 461

Kapellen 413f., 415, 426, 429, 432, 477

Ketten Petri 357, 443

Kirchenbuße 53, 63f., 76, 78f., 249, 491, 503

Kommemorationsprägungen 196-198

Konsekration 180, 187, 197-200, 495

Konzil von Serdika (342/3) 279, 280f., 496

Konzil v. Konstantinopel (381) 318, 320

Konzil von Chalkedon (451) 391f., 402

Konzil von Autun (561/605) 416f.

kulturelles Gedächtnis 3f., 7-10, 12, 15f., 17, 25, 77, 80

lapsi 35, 50, 63-65, 72, 144, 273, 294, 491

„Leoquelle“ (s. auch Petros Patrikios) $149 \mathrm{f}$.

Liber Pontificalis 261, 269, 276, 461, 481

Luciferianer 224f., 274

Lucius und Montanus-Akten $70 f$.

Manichäer 221f., 268, 287

Märtyrerakten (s. auch gesta martyrum Romanorum) 26, 73f., 144, 268

Martyrium 26, 68-70, 79, 207, 379, 491f.

Martyrologien/Legendare 37, 261f., 469

Memorialkultur 489f., 492, 506-508, 508-512, 515, 520-538

Messhäufigkeit 416f., 533

Monepiskopat 40, 216, 253, 325, 462

Montanisten 221, 287, 397

Musealisierung 23, 113

Novatianer 219, 222, 253-276, 286f., 326, 483

Nuklarisierung des städtischen Raums 1, 32f., 404-406, 446, 482, 489, 502, 534

Oblationen 208-210, 304, 418-424, 493, 507, 533f.

Opfercharakter der Messe 419-421, 487, 533

Oratorien 380-382, 391-393, 402, 500

Osterfest 217, 232, 247-249, 474

paenitentia publica (s. Kirchenbuße)

parentalia 57f., 181, 184, 513 
parentatio 183, 185, 190, 202, 206

Parochien 167f., 339f., 407, 417, 477

passio Anastasiae 372f., 433

passio Cantianorum 366-368

passio Felicis episcopi 449-451, 457, 462f., 465f., 469

passio Gallicani 107, 258, 264, 331, 357, 469

passio Perpetuae 25, 49-51, 67f., 73

passio Sebastiani 259f., 262f., 269-271, 276, 347, 433

Patronage (sozial) 216, 236f., 292, 335-337, 371, 376, 385-387, 391, 397, 401f., 499f., 504, 505, 508, 512, 514, 516, 519, 530f.

Patronage (Heilige) 292f., 295-300, 306, 315f., 328, 384, 387, 403, 488f., 497f., 500, 503, 504f.

Patrozinien 337-363, 376, 400f., 427, 489, 499

pauper Christi 532f., 535

pax 52-55, 65f., 72, 78, 294f., 306, 491, 497

Pelagianer 221, 287

Petrusmemoria in den röm. Heiligenlegenden 442-444

plebs Romana (als römische Kirchengemeinde) 240-242, 245f., 249, 303, 307, $324 \mathrm{f}$.

pompa funebris 183-185, 189, 386

pontifex maximus 115, 119, 148f., 316

praesentia der Heiligen 297-299, 328, 497

Primat des röm. Bfs. 317-324

Privatmesse 415, 418f., 486, 534

privatus und publicus 112, 120-122, 212, 378f., 385f., 403

proskynema 524

Prozessionen (s. auch Stationsliturgie) 1, 325, 408-411, 485, 502

refrigerium 41, 44-51, 55, 61, 66-68, 71-79, 167f., 257, 384, 490f., 506, 530

Reliquien 60, 209, 314, 322, 363-365, 376-378, 381f., 390, 413f., 418, 421, 486, 499f., 503, 507

Reliquientranslationen 21, 37, 42, 256, 259, 298, 314, 339, 341f., 348f., 352, 360, 363, 366, 400, 499, 503

res privata $115 f ., 121$

Reziprozität 13f., 55, 66f., 75f., 79, 491

Rompilger 31, 322f., 329, 348, 398, 406, 413, 443, 501

Schismen 30f., 37, 222-251, 294, 306, 325f., 408, 446, 495f., 501

- schismata inveterata 220-222, 326, 496

Senat, Senatsaristokratie 31f., 83-85, 88f., 96, 112f., 122-133, 138-141, 147, 152f., 179f., 182, 185, 197f., 235-237, 249, 291f., 310, 318, 330, 335-337, 363, 376-379, 386f., 401, 425, 473, 494, 498, 499, 512

Silvesterakten 146, 156f., $268 \mathrm{f}$.

social memory 5,10

Spielstätten und -kultur 191, 215, 236, 312, 409, 445, 510

Staatlichkeit $515 f$.

Stationsliturgie 32, 37, 232, 325, 331, 408, 410f., 430, 432, 485, 489, 502 
Statuen 336f., 387, 389f., 508-510, 513f.

Stiftungen 14f., 22, 61f., 169, 173-175, 338, 399, 490, 513f., 537

symmachianische documenta 276, 468

Synode von Aquileia (381) 288, $321 \mathrm{f}$.

Synode von Arles (314) $280 \mathrm{f}$.

Synode von Karthago (419) 332

Synode von Rom (378) 288

Synode von Rom (382) $320 f$.

Taufe 247, 249, 410, 451, 466, 477, 483, 501

Titelkirchen 167f., 223, 232-234, 239, 243, 246, 249, 325, 330-335, 338-363, 365f., 399, 408, 435, 439, 476, 499, 503

Totenkult (s. auch parentatio) 57, 78, 86, 164f., 167f., 171, 179-181, 182, 192-194, 200212, 213, 493-495

Totenmähler

- pagan 46, 57-59, 61f., 78, 490, 513f.

- christlich (s. refrigerium)

Totenmessen 417, 533f.

Tradition 297-303, 497

Tyrannentopik 127-130, 132, 152, 213, 494

urbs sacra 319,327

Valentinianer 217

valerianische Verfolgung 34f., 50, 63, 74, 218, 255

Vereine 27, 29, 58, 61, 215, 336, 397, 490, 492, 508, 513

Victoriaaltar 316, 386

Votivmesse 418-421, 486, 507, 533f.

Witwen 51, 216, 528

Xenodochien 335, 391

Zirkusparteien 226, 235-237, 405 
